\title{
GEOLOGIC CONTEXT, AGE CONSTRAINTS, AND SEDIMENTOLOGY OF A PLEISTOCENE VOLCANICLASTIC SUCCESSION NEAR MOUNT SPURR VOLCANO, SOUTH-CENTRAL ALASKA
}

by

Trystan M. Herriott, Christopher J. Nye, Richard D. Reger, Marwan A. Wartes, David L. LePain, and Robert J. Gillis

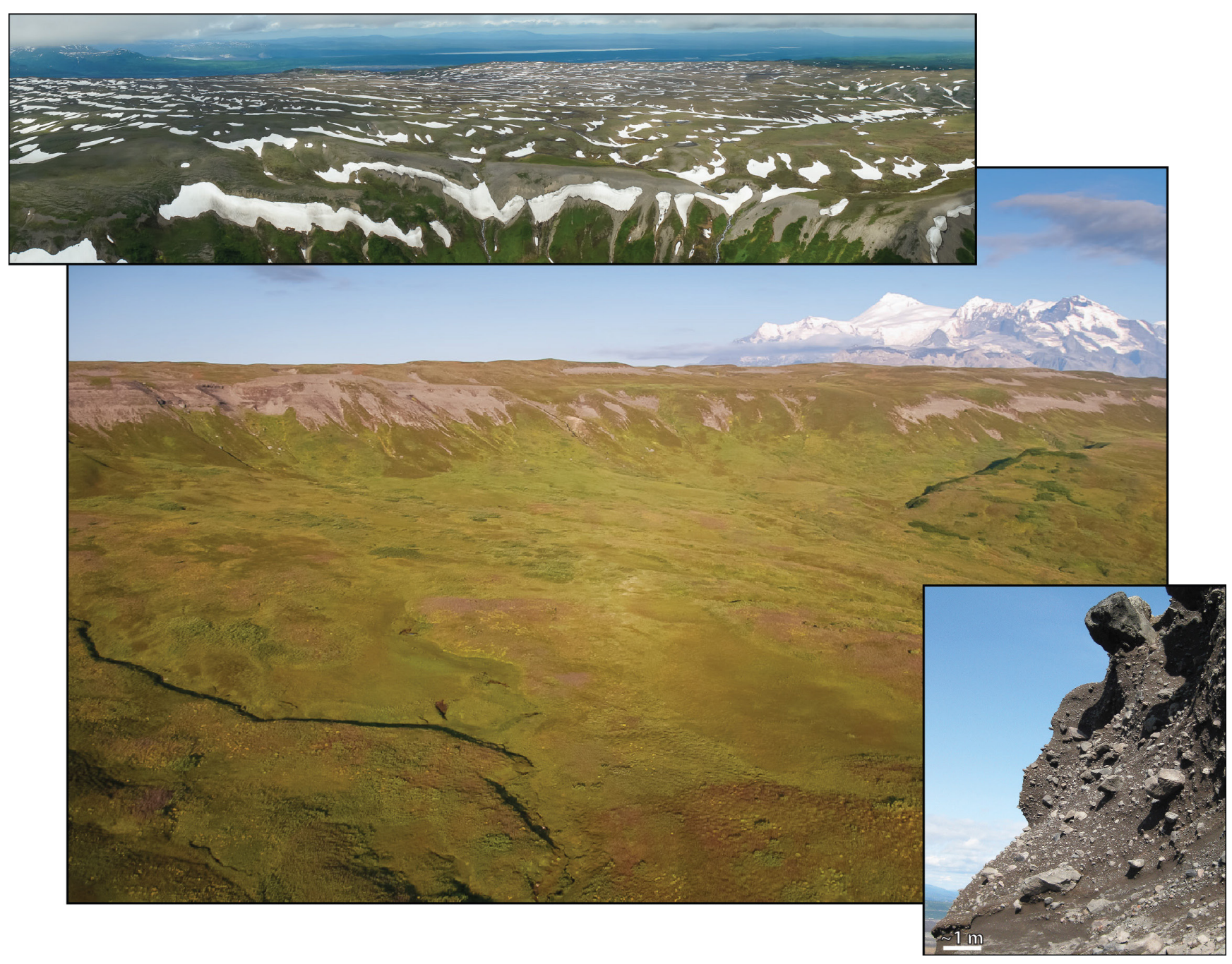

Published by

STATE OF ALASKA

DEPARTMENT OF NATURAL RESOURCES

DIVISION OF GEOLOGICAL \& GEOPHYSICAL SURVEYS 


\title{
GEOLOGIC CONTEXT, AGE CONSTRAINTS, AND SEDIMENTOLOGY OF A PLEISTOCENE VOLCANICLASTIC SUCCESSION NEAR MOUNT SPURR VOLCANO, SOUTH-CENTRAL ALASKA
}

Trystan M. Herriott, Christopher J. Nye, Richard D. Reger, Marwan A. Wartes, David L. LePain, and Robert J. Gillis

FRONT COVER, MAIN PHOTO. Oblique aerial view westward from below the surface elevation of an approximately $40 \mathrm{~km}^{2}$ plateau immediately south of Capps Glacier (southwestern Tyonek Quadrangle). Volcaniclastic strata exposed along the margins of the plateau are the focus of this paper. Mount Spurr $(3,374 \mathrm{~m}[11,070 \mathrm{ft}])$ is the conical, snow- and ice-covered peak (right skyline). Photograph by T.M. Herriott.

UPPER INSET. Oblique aerial view northeastward from above the volcaniclastic plateau's surface. Part of the topographically distinct southwestern plateau margin is visible in the foreground. Foreground field of view is approximately $1.5 \mathrm{~km}$. Photograph by T.M. Herriott.

LOWER INSET. Outcrop-scale view of very-thick-bedded, boulder-bearing volcaniclastic strata of this study. Photograph by T.M. Herriott.

\section{Report of Investigations 2014-2}

\author{
State of Alaska \\ Department of Natural Resources \\ Division of Geological \& Geophysical Surveys
}




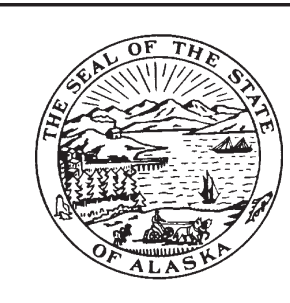

STATE OF ALASKA

Sean Parnell, Governor

\section{DEPARTMENT OF NATURAL RESOURCES}

Joe Balash, Commissioner

\section{DIVISION OF GEOLOGICAL \& GEOPHYSICAL SURVEYS}

Steve Masterman, Acting State Geologist and Director

Publications produced by the Division of Geological \& Geophysical Surveys (DGGS) are available for free download from the DGGS website (www.dggs.alaska.gov). Publications on hard-copy or digital media can be examined or purchased in the Fairbanks office:

\section{Alaska Division of Geological \& Geophysical Surveys 3354 College Rd., Fairbanks, Alaska 99709-3707 \\ Phone: (907) 451-5020 Fax (907) 451-5050 \\ dggspubs@alaska.gov \\ www.dggs.alaska.gov}

Alaska State Library

State Office Building, 8th Floor 333 Willoughby Avenue

Juneau, Alaska 99811-0571

Elmer E. Rasmuson Library University of Alaska Fairbanks Fairbanks, Alaska 99775-1005
Alaska Resource Library \& Information Services (ARLIS)

3150 C Street, Suite 100

Anchorage, Alaska 99503-3982

University of Alaska Anchorage Library 3211 Providence Drive Anchorage, Alaska 99508-4614 


\section{CONTENTS}

Abstract

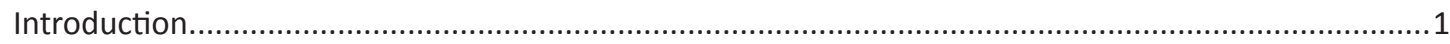

Previous Studies.

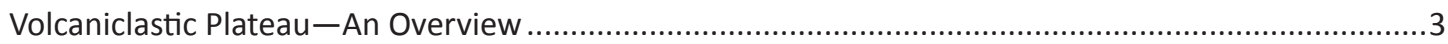

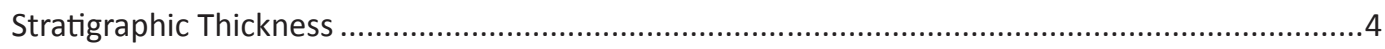

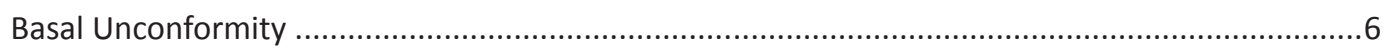

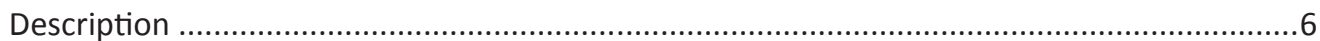

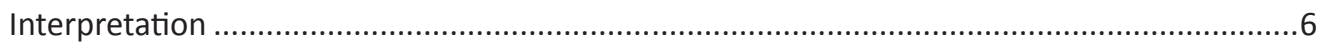

Bedding Orientations

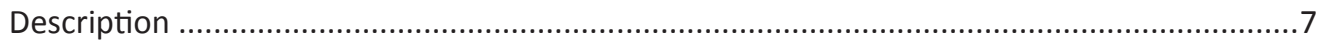

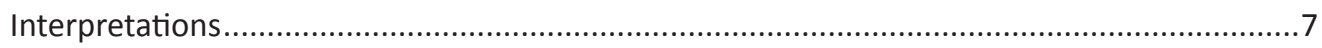

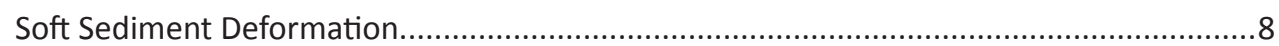

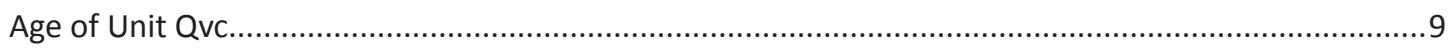

U-Pb Detrital Zircon Geochronology-Qvc Maximum Depositional Age ....................................10

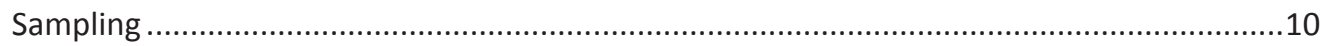

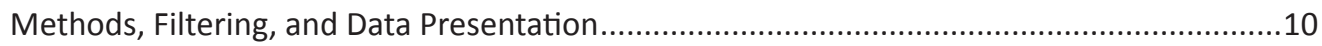

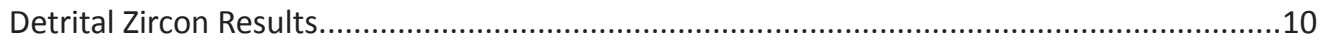

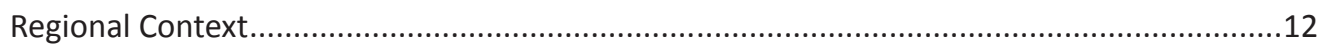

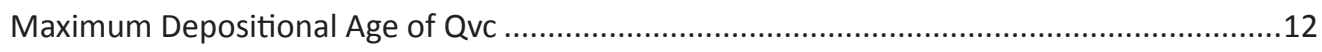

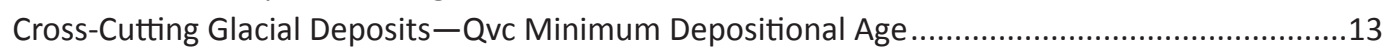

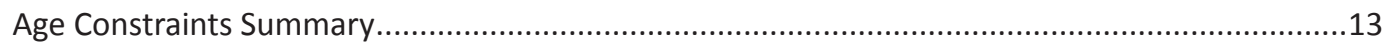

Sedimentology

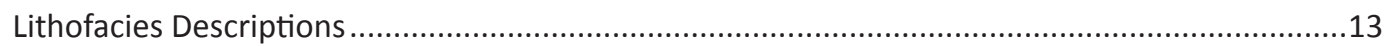

Lithofacies 1-Matrix-Supported Structureless Sandy Conglomerate..................................13

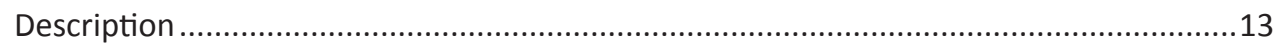

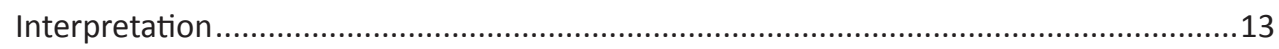

Lithofacies 2-Clast-Supported Structureless to Crudely Organized Conglomerate ................13

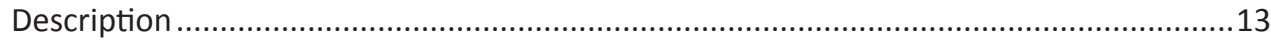

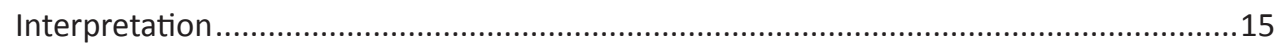

Lithofacies 3-Faintly Horizontally Stratified Gravelly Sandstone ......................................15

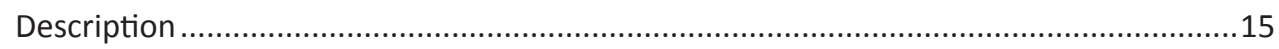

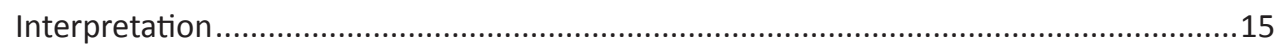

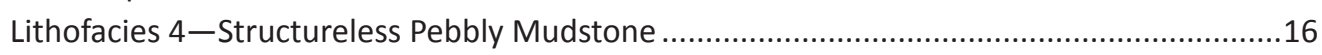

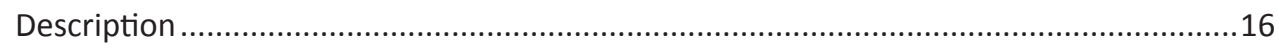

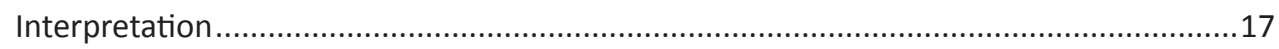

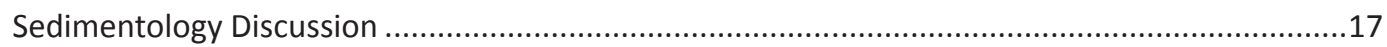

Volcanogenic Sediment-Laden Flows - Lithofacies 1-4 as Lahar Deposits .............................17

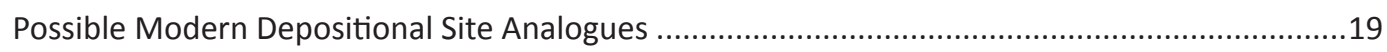

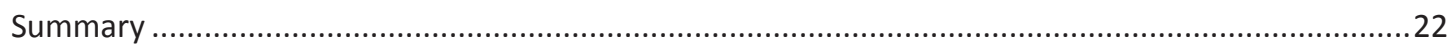

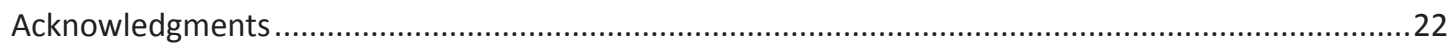

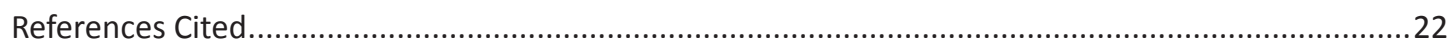

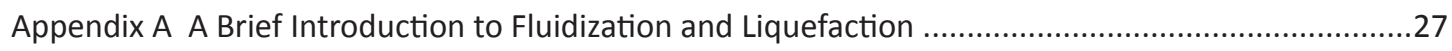

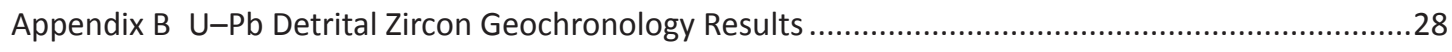

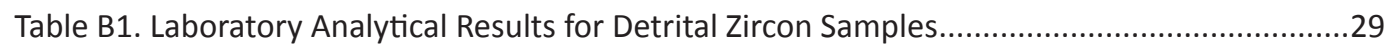

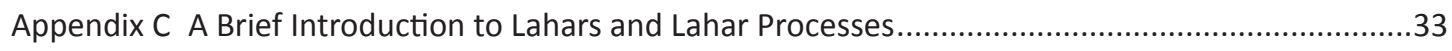




\section{FIGURES}

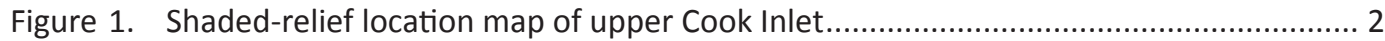

2. Google $\mathrm{Maps}^{\circledR}$ satellite image portraying the physiographically distinct approximately $40 \mathrm{~km}^{2}$ volcaniclastic plateau of this study ......................................... 3

3. Simplified geologic map of the volcaniclastic plateau and surrounding area modified from Gillis and others (in preparation) ..................................................................... 4

4. Field photographs exhibiting Qvc outcrop character, stratigraphic thickness, and

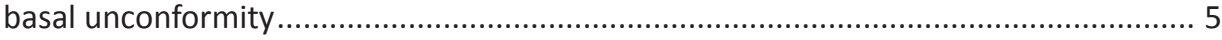

5. Oblique Google Earth ${ }^{\oplus}$ view southwestward of the volcaniclastic plateau .................... 6

6. Field photographs of deformed Qvc strata and associated clastic dikes ........................ 8

7. Histograms and relative probability curves for $\mathrm{U}-\mathrm{Pb}$ detrital zircon results ................ 11

8. Field photographs of lithofacies 1 (matrix-supported, structureless, sandy

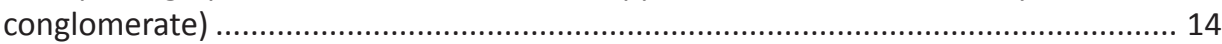

9. Field photographs of lithofacies 2 (clast-supported, structureless to crudely

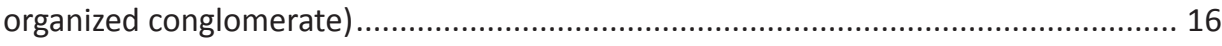

10. Field photographs of lithofacies 3 (faintly horizontally stratified, gravelly sandstone) 18

11. Field photographs of lithofacies 4 (structureless, pebbly mudstone) ......................... 20

12. Sediment-water continuum flow diagram modified from Smith and Lowe (1991) ..... 21

\section{TABLES}

Table 1. Sample station localities. 10

2. Maximum depositional ages as determined from detrital zircon data presented in this study 


\title{
GEOLOGIC CONTEXT, AGE CONSTRAINTS, AND SEDIMENTOLOGY OF A PLEISTOCENE VOLCANICLASTIC SUCCESSION NEAR MOUNT SPURR VOLCANO, SOUTH-CENTRAL ALASKA
}

\author{
Trystan M. Herriott ${ }^{1}$, Christopher J. Nye ${ }^{1}$, Richard D. Reger ${ }^{2}$, Marwan A. Wartes ${ }^{1}$, David L. LePain ${ }^{1}$, and Robert J. Gillis ${ }^{1}$
}

\begin{abstract}
A physiographically prominent, approximately $40 \mathrm{~km}^{2}$ plateau lies roughly $20 \mathrm{~km}$ east of Mount Spurr volcano, northwestern Cook Inlet region, Alaska, and comprises the preserved remnant of a volcaniclastic succession, designated in this study as map unit Qvc. Although this readily mappable package of volcaniclastic rocks has been recognized in numerous studies during the past five decades, uncertainties regarding its age and origin have persisted. Qve generally consists of structureless, thick-bedded, moderately indurated, subhorizontally dipping, matrix- to clastsupported granule-boulder conglomerate, gravelly sandstone, and gravelly mudstone. Clasts and matrix are chiefly dense to vesicular intermediate(?) lava fragments and pumiceous to scoriaceous pyroclasts. The unit is thickest to the north, where an approximately 275-m-thick section discontinuously crops out south of Capps Glacier. Field relations and the mapped surface trace of a sub-Qvc angular unconformity suggest that marked topographic relief on a paleosurface — eroded into underlying Paleogene and Neogene-age strata—was established prior to deposition of the volcaniclastic succession. Several exposures of chaotically folded Qve strata are associated with clastic dikes; these features are interpreted to record soft sediment deformation resulting from fluidization and/or liquefaction of watersaturated sandy deposits in an environment subject to earthquake-induced shaking, high instantaneous sedimentation rates, or a combination thereof.

$\mathrm{U}-\mathrm{Pb}$ detrital zircon geochronology maximum depositional age determinations indicate the youngest sampled strata are unlikely to be older than $0.40 \pm 0.09 \mathrm{Ma}$, but may be as young as or younger than $0.31 \pm 0.14 \mathrm{Ma}$; the oldest sampled strata are unlikely to be older than 1.0 Ma, but may be no older than $0.48 \pm 0.05 \mathrm{Ma}$. This study's most statistically robust, precise, and conservative maximum depositional age is $0.45 \pm 0.06 \mathrm{Ma}$, incorporating the youngest grain ages from all sampled strata that overlap at 2-sigma $(n=19)$. Moraines correlated to the Marine Isotope Stage (MIS) 4 penultimate glaciation interval locally onlap the eroded plateau, providing a minimum age of $\sim 75 \mathrm{ka}$ for the unit. In conjunction, these new age constraints chiefly limit Qve sedimentation to middle and late Pleistocene time but prior to MIS 4, a considerable improvement over previous age estimates that ranged widely from Miocene through Holocene.

We interpret Qve to be a valley-fill succession that records sedimentation from volcanogenic debris flows and hyperconcentrated flows (lahars) at a low-gradient alluvial fan or floodplain depositional site. Texturally and compositionally similar laharic strata are reported elsewhere within several tens of kilometers of continental arc volcanoes, consistent with the plateau's proximity to the modern volcanic arc of upper Cook Inlet. This lahar-prone, volcanoproximal depositional system was evidently subsequently dismantled by extensive erosion during and/or after MIS 4. The remaining volcaniclastic deposits persist in exposures along the margins of the plateau, with no recognized proximal or distal equivalents at this time; however, we propose that the source of volcaniclastic detritus for this unit was an arc volcano - possibly ancestral Mount Spurr - toward the west.
\end{abstract}

\section{INTRODUCTION}

Recent geologic studies in the Beluga, Chuitna, and Chakachatna rivers area of south-central Alaska were led by the Alaska Division of Geological \& Geophysical Surveys (DGGS), in collaboration with the Alaska Division of Oil \& Gas and the U.S. Geological Survey (USGS), and focused on the Cenozoic stratigraphy along Cook Inlet forearc basin's northwestern margin (fig. 1). To elucidate locally complex and enigmatic structural and stratigraphic relations in the region, we conducted 1:63,360-scale geologic mapping of $\sim 2,220 \mathrm{~km} 2$ in the Tyonek Quadrangle (Gillis and others, in preparation; red box in fig. 1). Mapping was largely completed during the 2009 and 2010 field seasons, although the field program in this area was ongoing from 2007 through 2011.
The map area, which lies $\sim 60 \mathrm{~km}$ west of Anchorage, Alaska, extends from the northwestern coast of Cook Inlet near Tyonek, Alaska, westward to the axis of the modern volcanic arc along the southeastern flanks of the western Alaska Range (fig. 1). The uplands south of Capps Glacier (fig. 2) host a previously recognized but poorly understood package of volcaniclastic conglomerate, sandstone, and mudstone (map unit Qve of this study). This volcaniclastic succession is readily mappable and comprises a physiographically prominent "volcanic plateau" (usage after Yehle and others, 1983); this feature is referred to in this study as the volcaniclastic plateau or, more simply, plateau (fig. 2).

In this report, we describe the general characteristics of the volcaniclastic plateau, provide new age constraints for the 


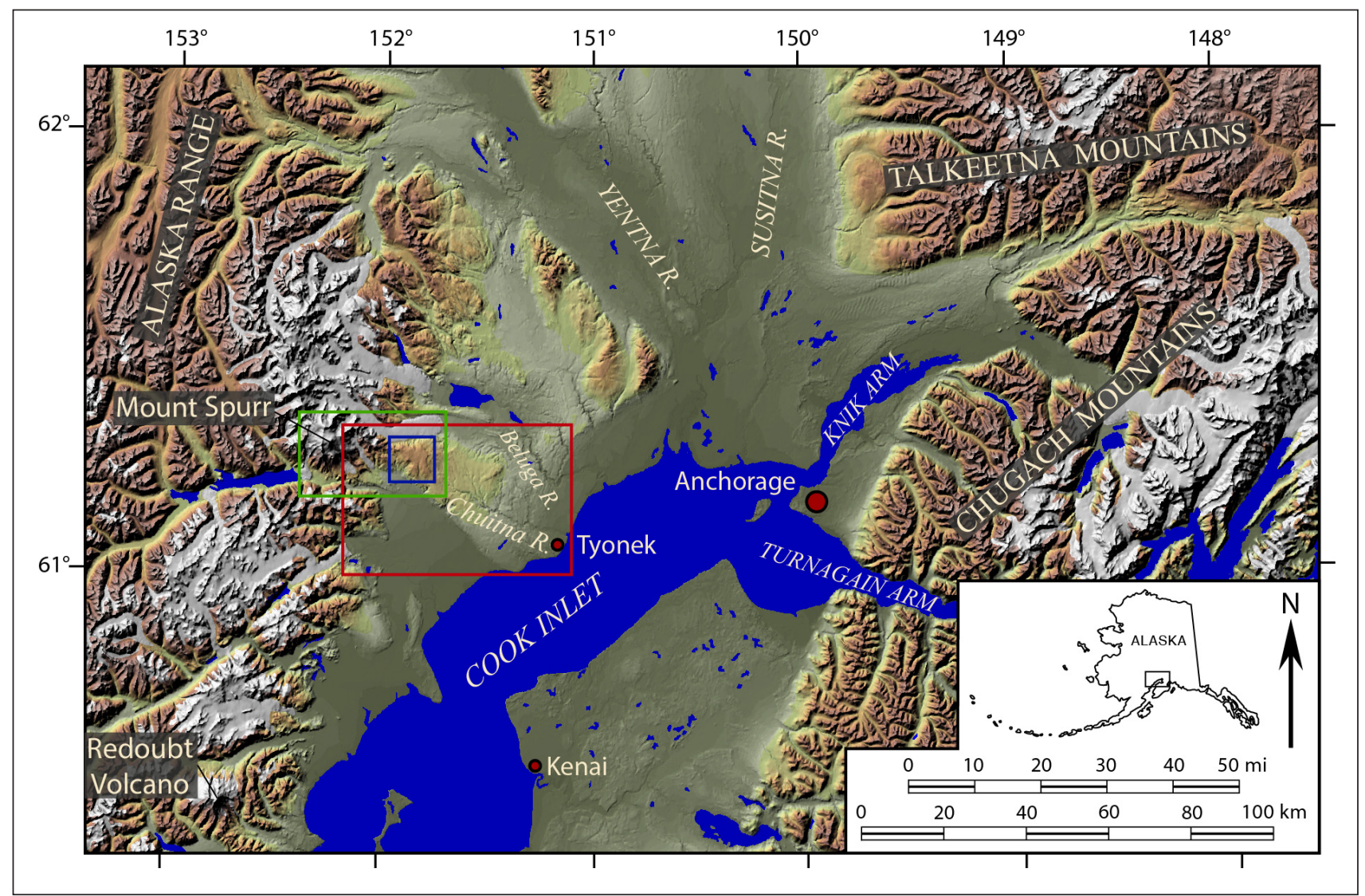

Figure 1. Shaded-relief location map of upper Cook Inlet. Recent DGGS-led geologic mapping (Gillis and others, in preparation) in the Tyonek-Capps Glacier area is outlined in red. See figure 2 (green outline) for detailed satellite imagery of the volcaniclastic plateau and surrounding area. See figure 3 (blue outline) for a geologic map of the volcaniclastic plateau. The shaded-relief base image is modified from the USGS's National Elevation Data Set Shaded Relief of Alaska poster (available for download at http://eros.usgs.gov/alaska-0).

deposits, present lithofacies descriptions and interpretations of the volcaniclastic strata, and synthesize our observations and lithofacies analysis to propose an environment of transport and deposition for the unit.

\section{PREVIOUS STUDIES}

Geologic studies in the northwestern Cook Inlet region were first conducted in 1927 and 1928 by the USGS, led by Stephen R. Capps. The Capps expeditions departed from Granite Point, approximately $15 \mathrm{~km}$ southwest of Tyonek, and traversed the uplands of the Chuitna River, southern aspects of Mount Spurr, and valleys north and west of Chakachamna Lake. During these expeditions, Capps (1935) mapped (1:250,000 scale) the southern volcaniclastic plateau as comprising both Quaternary glacial detritus and probable Kenai formation of Eocene age.

Following the early work by Capps, many subsequent geologic investigations in the Tyonek Quadrangle recognized the plateau and its deposits as a unique and discretely mappable unit. Barnes (1966) published the first detailed (1:63,360-scale) geologic map that encompassed the plateau, which he mapped as unit Tv and described as comprising locally well-stratified, variably indurated pyroclastic rocks consisting of lapilli tuff and volcanic breccias. Unit Tv was suggested to be potentially as old as Miocene, with Barnes hypothesizing that conspicuously "steeply dipping" beds predated the most recent episode of tectonism. However, he also permitted that the uppermost strata of the volcaniclastic succession may be as young as Pleistocene or even Holocene. A subsequent 1:250,000-scale USGS compilation map of Cook Inlet (Magoon and others, 1976) largely adopted mapping of the plateau by Barnes, and the unit label Tv was retained.

Preliminary 1:63,360-scale surficial geologic mapping by Yehle and others (1983) also recognized the volcaniclastic plateau as comprising a uniquely mappable unit, v, consisting of conglomeratic volcaniclastic deposits of Tertiary and Quaternary(?) age. Those authors also reported that the plateau surface is mantled by a $\geq 1.5$-m-thick pyroclastic fall deposit of Pleistocene(?) and Holocene age; recent work by Reger and others (in preparation) similarly describes a 1-2-m-thick mantling deposit of loess that primarily consists of "fine-grained Holocene tephras." Yehle and others (1983) were the first to explicitly propose transport mechanisms for the volcaniclastic deposits, suggesting that the unit records sedimentation from "volcanic mudflow and (or) pyroclastic flow" in a paleovalley "having a southeasterly gradient." This mapping also highlighted the nearly ubiquitous volcanic origin of the pebble-boulder-sized clasts, with only locally observed granitic or, rarely, other lithologies. 


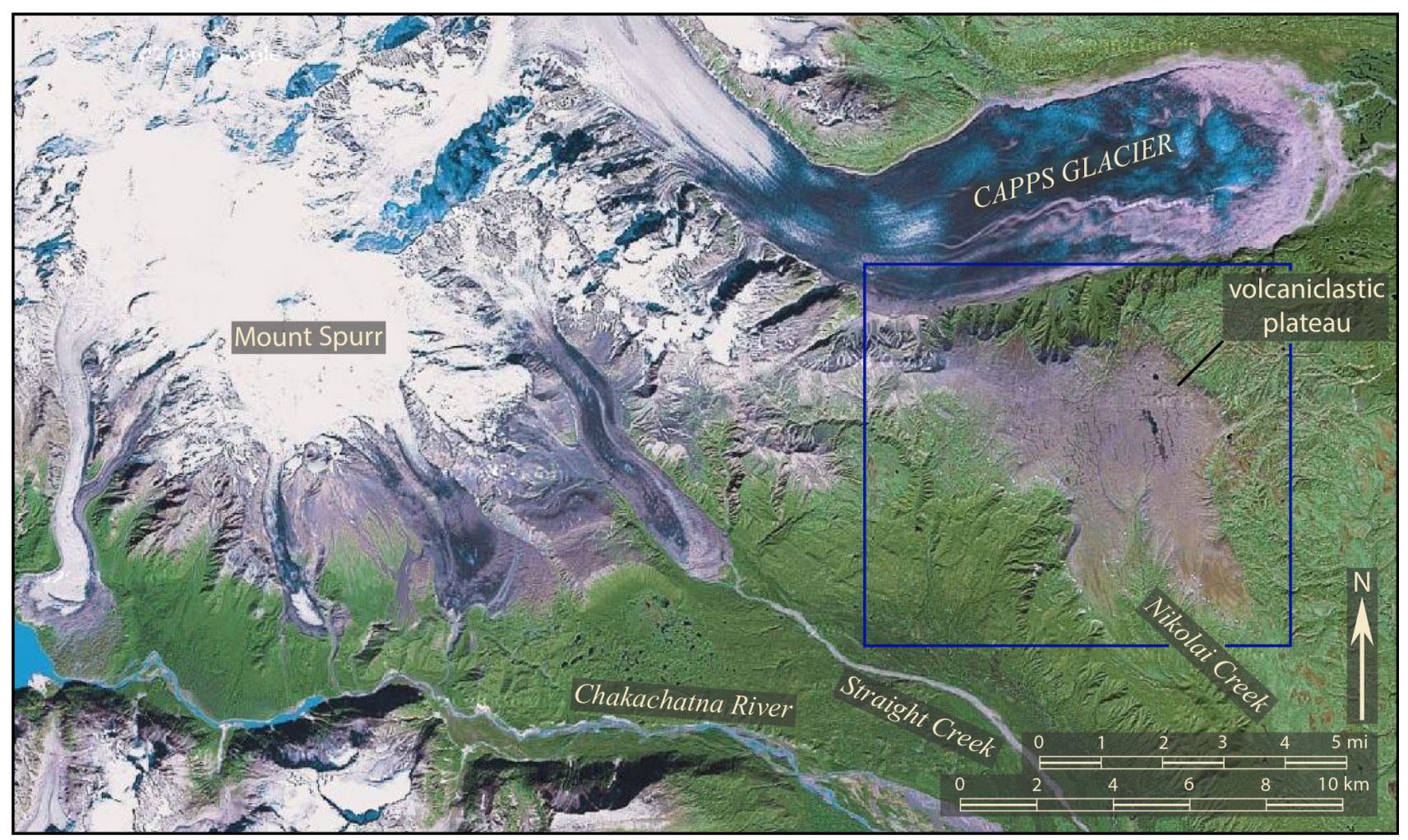

Figure 2. Google Maps satellite image portraying the physiographically distinct approximately $40 \mathrm{~km}^{2}$ volcaniclastic plateau of this study (at right of image). Qvc strata generally crop out at the perimeters of the plateau and along ridges and gullies immediately south of Capps Glacier. See figure 3 (blue outline) for a geologic map of the volcaniclastic plateau. Base image ${ }^{\circledR} 2010$ Google and TerraMetrics.

Tyonek Quadrangle mapping published in the most recent USGS 1:250,000-scale compilation map of Cook Inlet (Wilson and others, 2009, 2012) is largely adapted from Magoon and others (1976), although additional data were incorporated where applicable (for example, P.J. Haeussler and D.C. Bradley, USGS, unpublished data). Wilson and others $(2009,2012)$ reassigned the volcaniclastic plateau to their ridge-capping map unit Qhv, consisting of Holocene volcanic rocks (for example, andesite to basalt lava flows, sills, agglomerate, and lahar deposits) associated with regional eruptive centers. Furthermore, those authors also reattributed an outcrop belt north of the west-central portion of the northern plateau perimeter to the Paleocene and Eocene West Foreland Formation; these same exposures are mapped as Tv by Magoon and others (1976).

Although the volcaniclastic plateau and its deposits have been readily identified during the past five decades, the origin and age of these volcaniclastic strata have remained equivocal.

\section{VOLCANICLASTIC PLATEAU-AN OVERVIEW}

The volcaniclastic plateau, about $20 \mathrm{~km}$ east of Mount Spurr, has an approximately $40 \mathrm{~km}^{2}$ areal extent and, with a highest elevation of $946 \mathrm{~m}$ (labeled ' 3105 ' on map for its elevation in feet, named 'peak 3105 ' here for brevity; figs. 3 and 4A), is almost entirely above brush line. The northern edge of the plateau yields abruptly to steeply dissected terrain with north-trending gullies and ridges that terminate near the southern lateral moraine of Capps Glacier (fig. 4); some of these small drainages exhibit nearly $500 \mathrm{~m}$ of topographic relief across a north-south horizontal distance of $\sim 2 \mathrm{~km}$. Conversely, the eastern, southern, and western margins of the plateau typically consist of a topographic "shoulder" with approximately 25-75 m of relief and Qvc subcrop; the base of this shoulder is commonly between $670 \mathrm{~m}(2,200 \mathrm{ft})$ and $730 \mathrm{~m}(2,400 \mathrm{ft})$ elevation.

Strata that constitute the plateau dominantly consist of moderately to weakly indurated, conglomeratic to sandy to muddy volcaniclastic deposits of our map unit Qvc. The preserved erosional remnant of this volcaniclastic succession is thickest to the north immediately south of Capps Glacier, where several hundred meters of stratigraphic section are discontinuously exposed along the steep northern plateau margin (figs. 2-4). Unit Qvc thins to zero preserved thickness at its southernmost extent where the plateau is partially bifurcated by Nikolai Creek (fig. 3). Beyond portions of the eastern, western, and northern perimeters of the plateau, geologic mapping indicates that Qvc strata overlie the Paleocene and Eocene West Foreland Formation, probable Oligocene Hemlock Conglomerate, and Oligocene and Miocene Tyonek Formation (fig. 3; stratigraphic ages from Wilson and others, 2009, 2012). Exposures of these formations that are older than Qvc, which generally become younger from west to east, were not observed in the heavily vegetated region south of the plateau. 


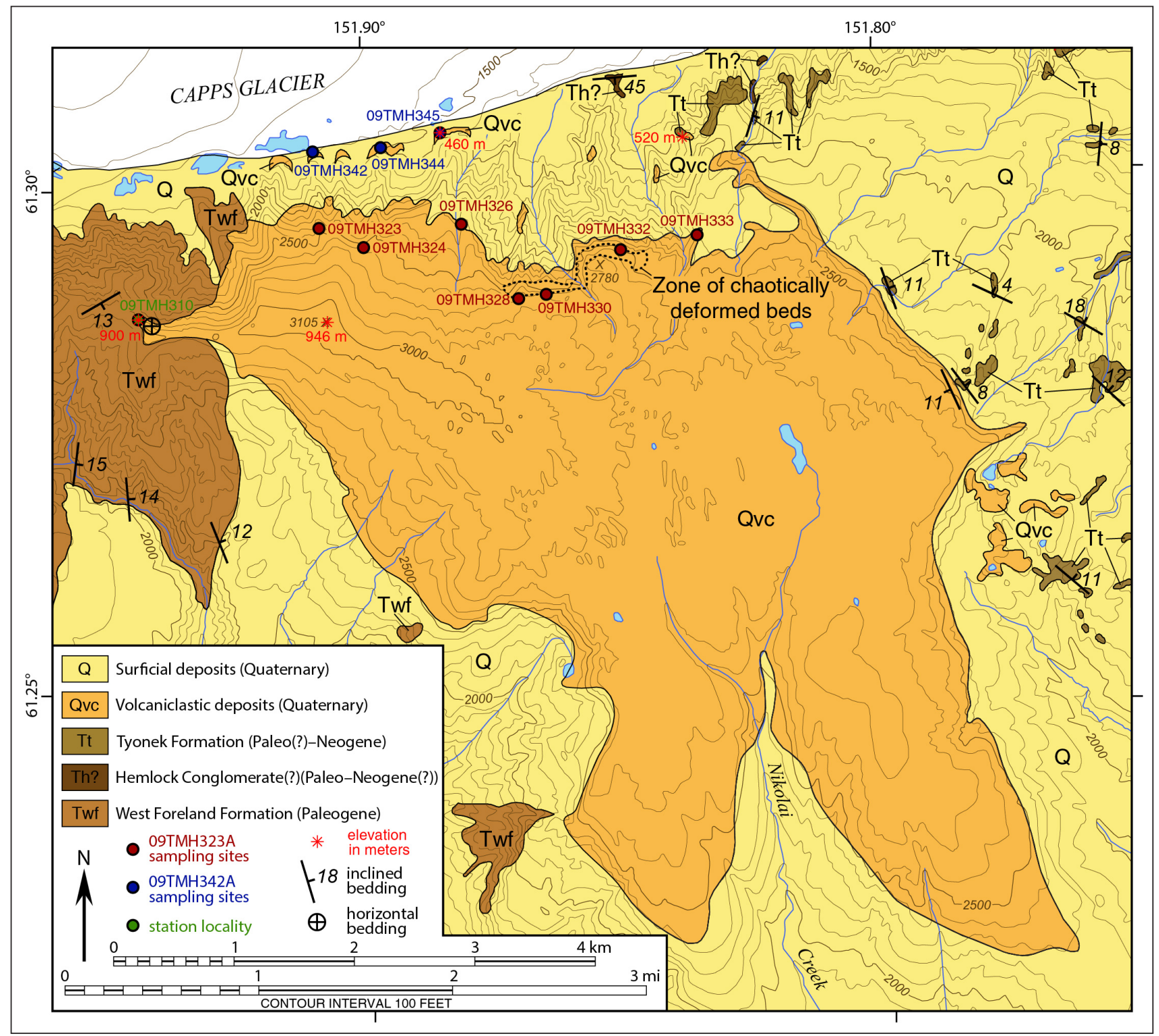

Figure 3. Simplified geologic map of the volcaniclastic plateau and surrounding area modified from Gillis and others (in preparation). Qvc overlies, with angular discordance, Eocene to Miocene-age strata of the West Foreland Formation (Twf), probable Hemlock Conglomerate (Th?), and Tyonek Formation (Tt). Elevations noted in red (marked with asterisks), observation station localities, and sampling sites for composited samples 09TMH323A and 09TMH342A (table 1) are discussed in this paper.

\section{STRATIGRAPHIC THICKNESS}

The volcaniclastic succession has undergone significant post-depositional erosion and its original thickness is not known. Neither the lowermost exposed interval (460 m elevation at station 09TMH345; fig. 4A) nor the stratigraphically uppermost preserved strata (946 m elevation at peak 3105) represent the depositional bottom (see Basal Unconformity, below) or top of the unit, respectively. The thickest remnant section is south of Capps Glacier, where a map-scale thickness calculation ${ }^{3}$ suggests Qvc is approximately $275 \mathrm{~m}$ thick (fig. 4A). This estimate assumes a bedding dip of $6^{\circ}$ north- ward (see Bedding Orientations, below), but the thickness there may be greater if the dip amount is less than $6^{\circ}$ (for example, a $0^{\circ}$ dip would render a unit thickness of $486 \mathrm{~m}$ ); a steeper dip would yield a smaller thickness estimate, although our field observations indicate this is unlikely. Regardless of the noted uncertainty of the unit's greatest preserved remnant thickness, our work suggests that Qve is many hundreds of meters thick and may have been thicker prior to extensive erosion that isolated the volcaniclastic succession within a local topographic high at the plateau. 
Figure 4. Field photographs exhibiting Qvc outcrop character, stratigraphic thickness, and basal unconformity. Photographs by T.M. Herriott.

A. Oblique aerial view southwestward of gray- to brown-colored volcaniclastic strata of Qvc that crop out in gullies and along ridges north of the plateau. Outcrop at toe of ridge (station locality 09TMH345; yellow arrow) consists of Qvc at $460 \mathrm{~m}$ elevation. An approximately 275-m-thick section of Qvc is exposed here. Rubble at photo lower right is within the southern lateral moraine of Capps Glacier.

B. Oblique aerial view westward of a verythickly-bedded package of Qvc that dips approximately $5^{\circ}-7^{\circ}$ northward (at right of photo; dashed red lines approximate bedding traces). Capps Glacier is at upper right of photo and Mount Spurr is partly obscured by clouds along the skyline at left of photo.

C. Oblique aerial view southeastward of gently-southwest-dipping $\left(\sim 12^{\circ}-14^{\circ}\right)$ strata of Qvc overlying poorly exposed Tyonek Formation (Tt); Tt locally dips gently east to southeast at $11^{\circ}-12^{\circ}$. The unconformity here (dashed yellow line at 520 m elevation; see text and fig. 5) is obscured by slope wash beneath the prominent Qvc exposure and exhibits a relative angular discordance between $\mathrm{Tt}$ and Qvc on the order of approximately $20^{\circ}-25^{\circ}$. Dashed red lines approximate bedding traces.
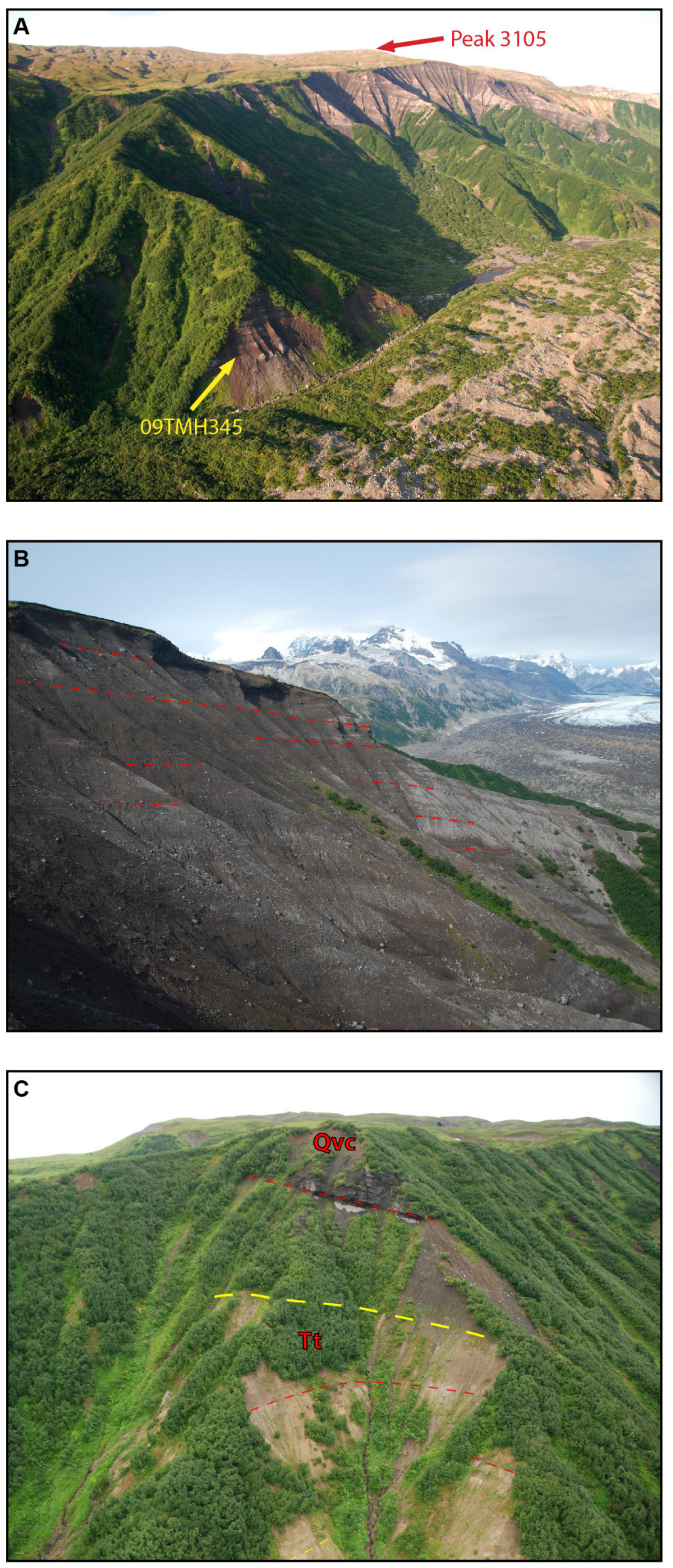


\section{BASAL UNCONFORMITY Description}

Geologic mapping demonstrates that Qvc overlies West Foreland and Tyonek Formations, as well as a probable intervening interval of Hemlock Conglomerate (fig. 3). Bedding in Qve is horizontal to dominantly subhorizontal, with notable exceptions discussed below, whereas West Foreland and Tyonek strata that crop out near the plateau chiefly dip gently (fig. 3). The sub-Qvc unconformity is well located but poorly exposed near its highest preserved elevation ( 900 $\mathrm{m}$ ) at station 09TMH310 (figs. 3 and 5); at this locality, horizontal Qve strata crop out within several stratigraphic meters of, and with an angularly discordant relation to, the West Foreland Formation. The lowest observed exposure of Qvc lies near the southern margin of Capps Glacier at $460 \mathrm{~m}$ elevation (station 09TMH345; figs. 3, 4A, and 5); however, the lowest elevation at which the unconformity is observed is approximately $520 \mathrm{~m}$, where Qvc strata dipping $\sim 12^{\circ}-14^{\circ}$ southwestward are underlain by Tyonek Formation strata locally dipping $11^{\circ}-12^{\circ}$ eastward to southeastward (fig. 4C). Our mapping suggests that the unconformity is generally limited to a maximum elevation of $670-730 \mathrm{~m}$ along the eastern, southern, and western plateau margins, where Qvc outcrops and subcrops yield to sparsely vegetated uplands (fig. 5). In areas where the unconformity is not directly observed, it is best constrained along the eastern and western plateau margins with exposures of West Foreland and Tyonek Formations locally providing minimum elevations for this

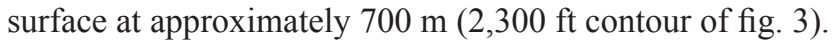
The minimum elevation of the unconformity south of the volcaniclastic plateau is poorly resolved due to a dearth of exposures in the underlying units.

\section{Interpretation}

Qve was deposited on a surface with apparently hundreds of meters of paleotopographic relief. This paleotopography is inferred from the varying present-day elevations of the basal unconformity that (1) descends from the $900 \mathrm{~m}$ elevation at 09TMH310 to (2) below the $460 \mathrm{~m}$ elevation at 09TMH345, then (3) ascends through the $520 \mathrm{~m}$ elevation locality, and (4) continues upward to the 670-730 m maximum elevation contours along the eastern, southern, and western edges of the plateau (fig. 5). This evidence of paleotopography-most strikingly expressed in the ridges and gullies south of Capps Glacier - may have been what led Yehle and others (1983) to suggest the Qvc deposits comprise a fill succession in a paleovalley with "southeasterly gradient."

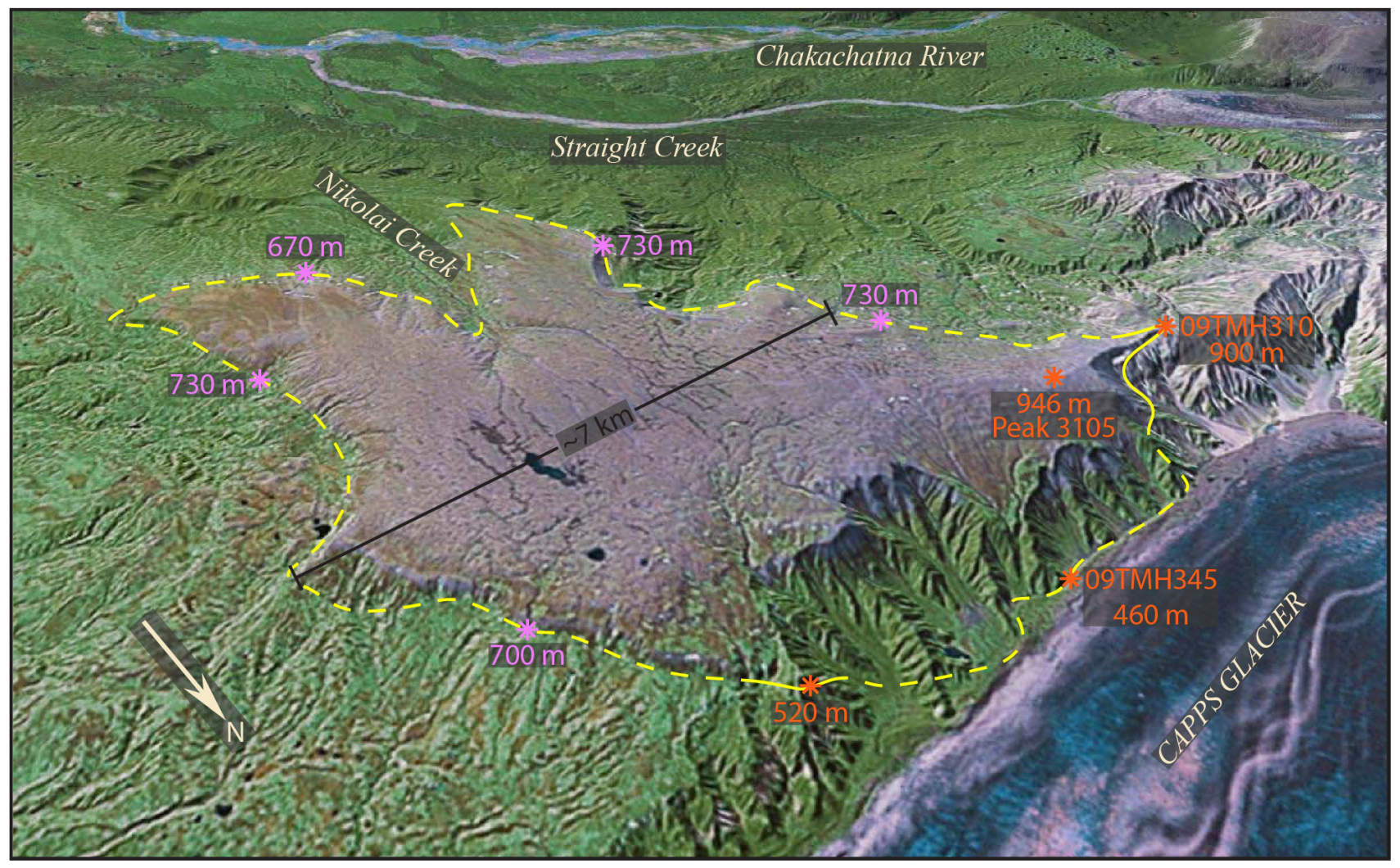

Figure 5. Oblique Google Earth ${ }^{\circledR}$ view southwestward of the volcaniclastic plateau. The sub-Qvc unconformity lies along or beneath the yellow outline, which is solid where directly observed and dashed along maximum elevation constraints (see text). Station locations and elevations labeled in orange are discussed in the text. Elevation labels in pink demarcate the general contour of the maximum elevation of the unconformity along the eastern, southern, and western plateau perimeters; the unconformity south of the plateau is poorly constrained. Substantial paleotopographic relief is recorded by the unconformity, most demonstrably along the dissected northern plateau margin south of Capps Glacier. Base image [02012 Google, TerraMetrics, and Digital Globe. 
Although our observations and inferences regarding the unconformity strongly suggest marked paleotopography, we consider these data to be inadequate to precisely define a paleovalley orientation, given the undoubtedly complex, four-dimensional (time and space) nature of the sub-Qvc paleosurface. Cassel and Graham (2011) suggested that observations of stratigraphic unconformity locations at the base of paleovalley fill successions may be misleading if employed to reconstruct paleochannel gradients or profiles, because basal erosional surfaces may be diachronous and amalgamated (Strong and Paola, 2008). Several observations help constrain the characteristics of the paleosurface, including: (1) a minimum of $\sim 440 \mathrm{~m}$ of apparent paleotopographic relief is recorded between stations 09TMH310 and 09TMH345, and a probable oblique cross-sectional view of a paleovalley exists along the steeply eroded northern plateau margin; (2) the sub-Qve unconformity is reasonably well located, and maintains a seemingly uniform elevation, along much of the eastern and western plateau margins; and (3) no reliable minimum elevation constraints for the unconformity south of the plateau can be determined, thus rendering a substantial "gap" in any potential paleotopographic reconstruction.

The field evidence indicates that the volcaniclastic rocks of Qvc record depositional infilling of a paleovalley; however, details regarding the orientation or depositional gradient of such a paleogeographic feature remain unclear. Further caution is warranted when considering paleotopographic gradient or paleovalley orientation reconstructions in light of documented Pliocene and Quaternary deformation in parts of Cook Inlet (Haeussler and others, 2000), which may have modified the orientation and/or geometry of the sub-Qvc paleosurface/unconformity.

\section{BEDDING ORIENTATIONS Description}

The commonly crudely bedded conglomeratic to sandy to muddy volcaniclastic strata of Qvc typically preclude direct measurements of bedding orientation, but strata throughout most of the plateau exposures are generally horizontal to subhorizontal. Compass sightings south of Capps Glacier suggest some thick packages in Qve dip up to $\sim 5^{\circ}-7^{\circ}$ northward (fig. 4B). Several observations along the northern plateau margin, however, indicate Qvc strata locally exhibit much greater bedding dips. Barnes (1966) estimated a $20^{\circ}$ southwest dip $\sim 1.5 \mathrm{~km}$ northeast of peak 2780 (labeled ' 2780 ' on map for its elevation in feet, here referred to as 'peak $2780^{\prime}$ ); it seems probable that Barnes' observation was made at or near the Qvc outcrop pictured in figure 4C. This locality is immediately above the $520 \mathrm{~m}$ elevation angular unconformity constraint (figs. 3 and 5) and occurs along a steep and heavily vegetated slope, but our oblique aerial observations suggest the probable true dip of Qvc there is $\sim 12^{\circ}-14^{\circ}$ toward the southwest. This component of Qvc may be up to several tens of meters thick and dips uniformly across a greater than 100 $m$ bedding-parallel extent. Yehle and others (1983) reported locally steeply dipping strata along the north-central to northeastern plateau perimeter, an area where we observed a conspicuously gently to steeply dipping, openly $\left(70^{\circ}-120^{\circ}\right.$ interlimb angle) to closely(?) $\left(30^{\circ}-70^{\circ}\right.$ interlimb angle) folded package of Qvc that crops out discontinuously for at least $\sim 1.5 \mathrm{~km}$ along the plateau's northern edge near peak 2780 (figs. 3 and 6A and B); these folded exposures are notably associated with clastic sandstone dikes. Our reconnaissance of outcrop-scale structures near peak 2780 largely suggests the folds are non-cylindrical and may exhibit curviplanar axial surfaces. This seemingly chaotically deformed zone (fig. 3) is up to several tens of meters thick and overlies a lithologically similar package of the more characteristically subhorizontally dipping Qve strata (fig. 6A).

The fold-associated clastic dikes are centimeters to several decimeters wide and have variable orientations, although they typically truncate bedding at moderate to high angles and exhibit tabular (figs. 6C and D) to irregular (fig. $6 \mathrm{E})$ geometries. Stratigraphic separation across the dikes is negligible to several decimeters. These clastic intrusions commonly have moderate to steep dips and do not appear to be folded. Muddy linings several millimeters to $1 \mathrm{~cm}$ thick are common along dike margins (figs. 6C-F). The clastic intrusion in figures $6 \mathrm{C}$ and $\mathrm{D}$ exhibits well developed internal stratification that is largely parallel to the dike walls, whereas some dikes are structureless to complexly stratified (fig. 6E). Thin $(<5 \mathrm{~cm})$ and irregularly shaped, structureless sandstone dikes with well developed muddy linings locally cross-cut subhorizontally dipping strata (fig. 6F). The dikes generally comprise poorly sorted, medium- to coarse-grained volcaniclastic sand and subordinate granules that are lithologically indistinguishable from the sand and granule components of the Qvc host strata.

\section{Interpretations}

The horizontal to subhorizontal bedding typical of Qve may reflect primary depositional dips, although the depositional settings likely to yield such relatively large primary dips are limited (for example, alluvial fans; Nilsen, 1982). Alternatively, the subhorizontal beds, in conjunction with locally observed gently dipping beds of figure $4 \mathrm{C}$ may in part result from tectonic deformation (also Barnes, 1966). As noted above, Haeussler and others (2000) documented Pliocene and younger deformation in upper Cook Inlet, with one seismically interpreted growth fold near the Beluga River $\sim 30$ $\mathrm{km}$ east of the plateau. Thus, subtle, kilometer-scale, gentle folding or tilting of Qvc is plausible, remaining consistent with our observations. In fact, barring a steep onlap relation of Qvc onto a buttress unconformity, such tectonic deformation may be required to account for the local $\sim 12^{\circ}-14^{\circ}$ dips of figure 4C. However, the chaotically folded section associated with clastic dikes has clearly undergone substantial deformation, but the overall context and strain recorded by these rocks do not appear to be consistent with tectonic deformation (see Soft Sediment Deformation, below). We do not regard any bedding orientations reported in this study to be affected by post-lithification mass wasting, although landslide deposits in the region have been observed and documented (Yehle and others, 1983; Reger and others, in preparation). 


\section{Soft Sediment Deformation}

The chaotic geometry and association of the folds near peak 2780 with clastic dikes are consistent with a soft sediment deformation origin for the observed strain (for example, Oomkens, 1966; Lowe, 1975; Farrell and Eaton, 1987). Clastic dikes may form in several ways, including: (1) intrusion of fluidized or liquefied sediment in grossly tabular geometries, and (2) infilling of open fissures or fractures from above (for example, Oomkens, 1966; Obermeier, 1996; Montenat and
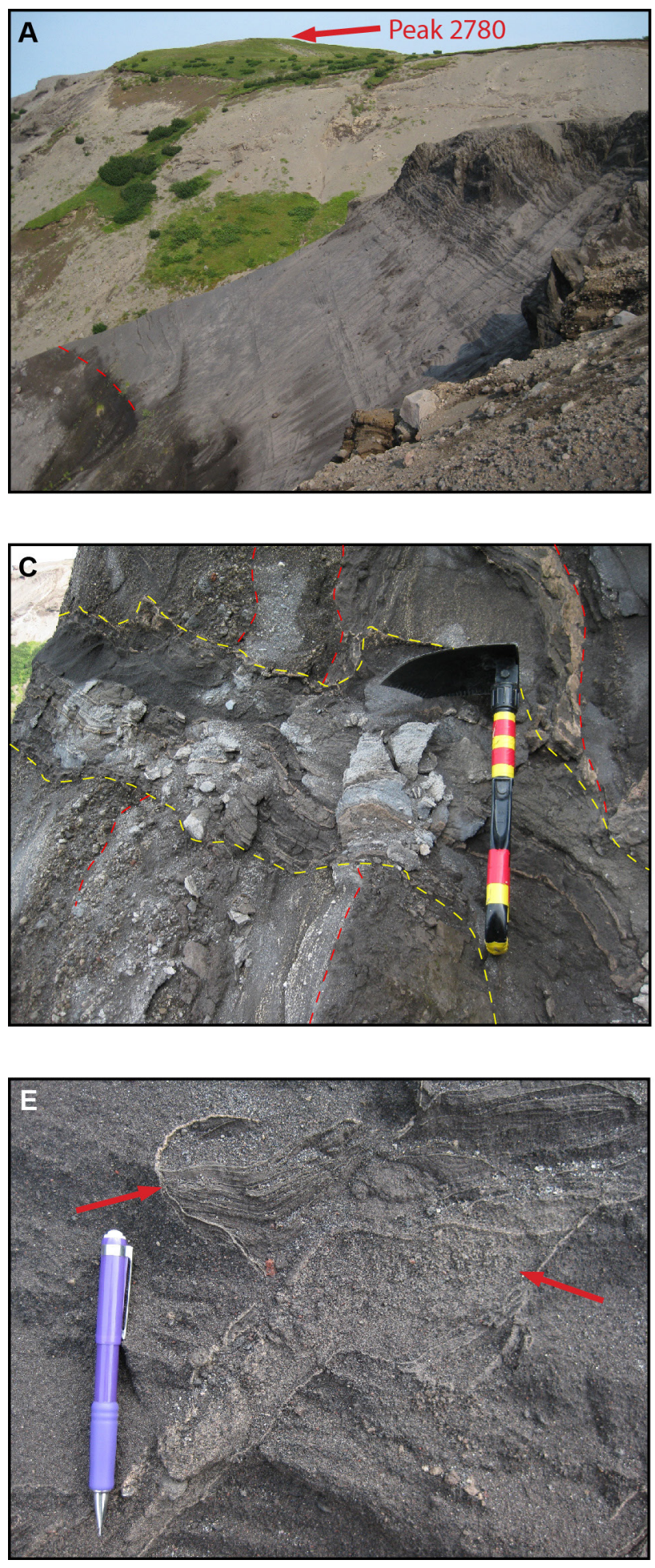

others, 2007; Morreti and Sabato, 2007). The observed Qvc clastic dike fabrics, particularly margin-parallel and steeply dipping stratification, are inconsistent with passive infilling of open fissures or fractures by overlying sediment sources or dike walls. We suggest the observed clastic dikes likely record rapid water and sediment escape from an underlying Qvc source, with the margin-parallel-laminated to structureless clastic dikes reflecting turbulent to laminar flow of escaping sediment-water slurries, respectively (Lowe, 1975).
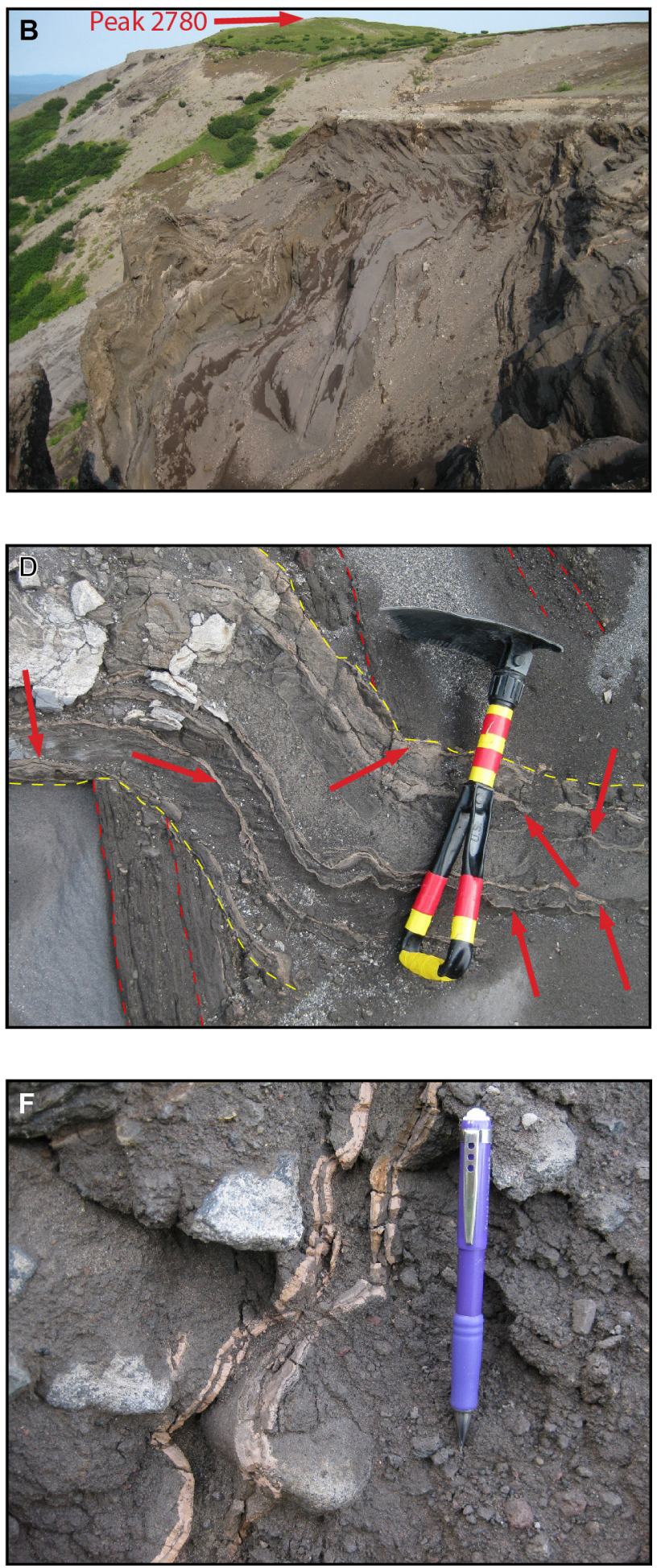
Mobilization of sediment transport in this proposed scenario may be attributable to both fluidization and liquefaction (see appendix A). Fluidization and liquefaction are commonly genetically linked, with pore water and sediment sourced from liquefied sediment bodies creating zones of escaping, fluidized to liquefied sediment along discrete escape paths (Lowe, 1975).

Mud-rich dike margins in Qvc (for example, fig. 6F) may be related to elutriation and winnowing of fines from dike bodies (Lowe and Guy, 2000), possibly during waning stages of dike emplacement (Walsh and others, 1995). Further, margin-parallel stratified dikes that exhibit many internal muddy linings may be the record of several pulses of fluidized sediment that intruded as discrete dikes sequentially emplaced along a coincident sediment-water escape path (Obermeier, 1996; Montenat and others, 2007).The complex fabric exhibited in the dike of figure 6E may record rapidly changing flow parameters (laminar to turbulent?) during sediment-water slurry escape and dike emplacement.

Figure 6. Field photographs of deformed Qvc strata and associated clastic dikes. Photographs by T.M. Herriott.

A. View eastward along the northern margin of the volcaniclastic plateau. Subhorizontal to subvertical bedding in folded Qvc strata crop out in the midground at left and right of photo, respectively, and similarly deformed strata are faintly evident in the background beneath peak 2780. Dashed red line marks the approximate base of the deformed zone, below which Qvc strata more characteristically dip subhorizontally.

B. View eastward, similar to A, highlights steeply dipping beds (foreground) in the deformed- and clastic-dikeintruded package of Qvc.

C. Sandstone dike is several decimeters thick, internally stratified, and cuts at high angles to folded bedding. This dike is subparallel to the shovel's blade; dashed yellow lines approximate dike margins. Bedding is subvertical and approximately parallel to the shovel's handle (45 $\mathrm{cm}$ long); dashed red lines approximate bedding traces.

D. Detailed view of dike pictured in C. Red arrows mark dike-margin-parallel, lighter-colored, mud-rich layers in the larger dike body. Dashed yellow and red lines approximate dike margins and bedding traces, respectively. Dike and bedding are obscured by slope wash at lower right of photo. Shovel is $45 \mathrm{~cm}$ long.

E. Sedimentary dike with irregular geometry that cuts at high angles to folded bedding. This dike exhibits complex internal organization and is in part structureless (right arrow) but is locally observed to be millimeter-scale laminated (lamina terminate at dike margins; left arrow). Pencil is $14 \mathrm{~cm}$ long.

F. Mud-lined dike with irregular geometry is approximately 2-4 cm thick and has a structureless, poorly sorted, granule-bearing, medium- to coarse-grained sandstone fill; mud lining is lighter-colored, clay-rich, and relatively thick $(\sim 1 \mathrm{~cm})$. This dike occurs in an undeformed, subhorizontal package of Qvc. Pencil is $14 \mathrm{~cm}$ long.
Regardless of the exact mean(s) of the chaotic Qvc deformation and clastic dike intrusion, our observations are consistent with sediment-water slurry escape along discrete, tabular paths that formed clastic dikes in plastically folded/ slumped - or contemporaneously folded/slumped? — volcaniclastic strata. Triggering mechanisms for the proposed deformation and intrusion of liquefied and/or fluidized sediment include, but are not limited to: (1) earthquake ground motion and (2) rapid or instantaneous deposition of a thick sediment body on a saturated substrate (see summaries in Lowe, 1975; Owen, 1987). Regional seismicity has likely been common throughout the evolution of the Cook Inlet forearc basin, and south-central Alaska has hosted one of the world's largest historic earthquakes (for example, Hansen and others, 1966; Plafker, 1969). In fact, extensive liquefaction (including clastic dike formation) occurred in the Cook Inlet region as a result of the Good Friday earthquake of 1964 (Foster and Karlstrom, 1967; Walsh and others, 1995). Additionally, rapid deposition of very thick beds of sand and gravel were likely commonplace during deposition of Qvc (see Sedimentology, below); geologically instantaneous application of such an overburden may have liquefied underlying, saturated, sand-rich horizons. Although it is unknown whether the depositional gradient during Qve sedimentation was, by itself, sufficiently steep to promote gravity-driven mass wasting, liquefaction of a buried sediment body could have been capable of instantaneously forming a detachment, allowing overlying non-liquefied strata to slump, deform plastically, and be intruded by clastic dikes sourced from the underlying liquefied sediment body.

Further study of the Qvc fold geometries near peak 2780 may shed additional light on the origin of these structures, but invoking fluidization/liquefaction of sand-rich sediment remains consistent with our observations, and contemporaneous triggering mechanisms were likely common.

\section{AGE OF UNIT QVC}

Previous maximum age constraints for Qve were set by the Oligocene and Miocene age of the underlying Tyonek Formation. However, it has been suggested that the volcaniclastic succession may in part be as young as Holocene (Barnes, 1966; Wilson and others, 2009, 2012) or, more generally, Quaternary (Magoon and others, 1976; Yehle and others, 1983). We are not aware of any previously published minimum age constraints for Qvc, although a concurrent study reports a latest Pleistocene minimum age based on cross-cutting relations of glacial deposits (Reger and others, in preparation; summarized below).

Directly dating volcaniclastic successions that lack unequivocally contemporaneous pyroclastic deposits or intercalated lavas is challenging due to the likelihood of significant incorporation of pre-existing detrital material into sedimentation units either during eruption events or by later reworking. However, geologically significant radioisotopic age constraints for such a volcaniclastic succession can be attained by maximum age determinations of the youngest population of individual grain ages within a sample. This 
approach typically requires analysis of tens to about 100 detrital grains (Dodson, 1988; Vermeesch, 2004) of, for example, zircon, apatite, or potassium-bearing mineral phases. Although Qve detritus is dominantly volcanogenic, primary volcanic deposits (such as ash fall tuff) without a significant detrital component were not observed during this study. We employed U-Pb geochronology of detrital zircons to establish a maximum depositional age for Qvc.

\section{U-PB DETRITAL ZIRCON GEOCHRONOLOGY- QVC MAXIMUM DEPOSITIONAL AGE}

Detrital zircon geochronology can yield meaningful maximum depositional ages for sedimentary rocks - especially in basins with contemporaneous regional volcanism-with several studies achieving good to excellent agreement between stratal age and the youngest detrital zircon ages (for example, Nelson, 2001; Dickinson and Gehrels, 2009a). The use of detrital zircon maximum depositional ages has become increasingly common in stratigraphic and tectonic studies where rocks of suitable composition or lithology for event dating are otherwise lacking, or when additional age constraints are necessary (for example, Fildani and others, 2003; Surpless and others, 2006; DeCelles and others, 2007; Bradley and others, 2009). Nevertheless, interpreting the geologic significance of detrital zircon ages in the context of maximum depositional age constraints requires careful consideration of the individual grain ages and the statistics of any population of ages (Dickinson and Gehrels, 2009a).

\section{Sampling}

We collected two detrital zircon samples from sand-rich volcaniclastic strata of Qvc. Samples 09TMH323A and 09TMH342A (table 1) were composited from material collected at seven and three field localities, respectively, with the former collected from the uppermost horizons of Qvc that crop out along the northern plateau edge and the latter

Table 1. Sample station localities. Samples 09TM $\neg$ H323A (stratigraphically uppermost strata) and 09TMH342A (stratigraphically lowermost strata) were composited from material collected at the stations recorded in the right column. See figure 3 for sampling site locations.

\begin{tabular}{|c|c|}
\hline Sample & Station \\
\hline \multirow{4}{*}{ 09TMH323A } & 09TMH323 \\
\cline { 2 - 2 } & 09TMH324 \\
\cline { 2 - 2 } & 09TMH326 \\
\cline { 2 - 2 } & 09TMH328 \\
\cline { 2 - 2 } & 09TMH330 \\
\cline { 2 - 2 } & 09TMH332 \\
\hline \multirow{5}{*}{ 09TMH342A } & 09TMH333 \\
\cline { 2 - 2 } & 09TMH342 \\
\cline { 2 - 2 } & 09TMH344 \\
\cline { 2 - 2 } & 09TMH345 \\
\hline
\end{tabular}

collected from the lowermost strata exposed immediately south of the Capps Glacier moraine (fig. 3). An approximately 200-m-thick section of Qve strata lies between the two sampled intervals. Sample names are adopted after the first field locality where composite sampling began for that stratigraphic interval (for example, 09TMH323). Several kilograms of medium- to coarse-grained sand were collected for each composited sample. Samples were collected with a rock hammer and a small folding shovel, taking care to avoid incorporating modern sediment.

\section{Methods, Filtering, and Data Presentation}

Detrital zircon samples were analyzed for $\mathrm{U}-\mathrm{Pb}$ geochronology by Apatite to Zircon, Inc., via laser ablation-inductively coupled plasma-mass spectrometry (LA-ICP-MS; for example, Chang and others, 2006) at Washington State University in Pullman, Washington. See Hults and others (2013) for analytical methods. One hundred eight zircons were analyzed from sample 09TMH323A, yielding 62 concordant ages; three pre-Proterozoic age grains were discarded due to exceedingly large errors (200\%). One hundred ten zircons were analyzed from sample 09TMH342A, yielding 95 concordant ages. See appendix $\mathrm{B}$ for detailed $\mathrm{U}-\mathrm{Pb}$ analytical results, including grain ages and isotopic data.

The degree to which ${ }^{206} \mathrm{~Pb} /{ }^{238} \mathrm{U}$ and ${ }^{206} \mathrm{~Pb} /{ }^{207} \mathrm{~Pb}$ ages from a single analyzed zircon are discordant ${ }^{4}$ is commonly calculated and used to filter reported ages, which are generally the ${ }^{206} \mathrm{~Pb} /{ }^{238} \mathrm{U}$ results for grains younger than $0.8-1.0 \mathrm{Ga}$ (see review by Gehrels, 2012; also Gehrels, 2000; Bradley and others, 2009; Dickinson and Gehrels, 2009b). However, Gehrels (2012) discouraged the use of discordance-based filtering of zircon ages younger than $100 \mathrm{Ma}$ due to the difficulty in determining reliable ${ }^{206} \mathrm{~Pb} /{ }^{207} \mathrm{~Pb}$ ages for these "young" grains. Similarly, Bradley and others (2009) did not apply a discordance filter for detrital zircon samples dominantly consisting of ages younger than $200 \mathrm{Ma}$. During the current study, only nine individual zircons yielded ages older than $200 \mathrm{Ma}$ (disregarding the three pre-Proterozoic grains noted above) and we do not apply a discordance filter to any of the data. All results are plotted using Isoplot 4.15 (Ludwig, 2008), and errors are reported at 2-sigma.

\section{Detrital Zircon Results}

Detrital zircon ages from sample 09TMH323A range from Proterozoic to Pleistocene; grain-age distribution is: Proterozoic (5), Paleozoic (3), Jurassic (5), Cretaceous (15), Paleocene (6), Eocene (1), Pliocene (1), and Pleistocene (23) ( $n=59$ of 62 concordant ages) (figs. 7A and B; appendix B). Sample 09TMH342A yielded detrital zircon ages that similarly range from Proterozoic to Pleistocene; grain-age distribution is: Proterozoic (1), Cretaceous (32), Paleocene (60), and Pleistocene (2) ( $n=95$ of 95 concordant ages) (figs. 7C and D; appendix B). The two samples largely exhibit latest Early Cretaceous through Pleistocene zircon ages from

${ }^{4}$ Discordance $=100-\left(100 \times\left[\left({ }^{206} \mathrm{~Pb} /{ }^{238} \mathrm{U}\right.\right.\right.$ age $) \div\left({ }^{206} \mathrm{~Pb} /{ }^{207} \mathrm{~Pb}\right.$ age $\left.\left.)\right]\right)($ after Gehrels, 2012). 


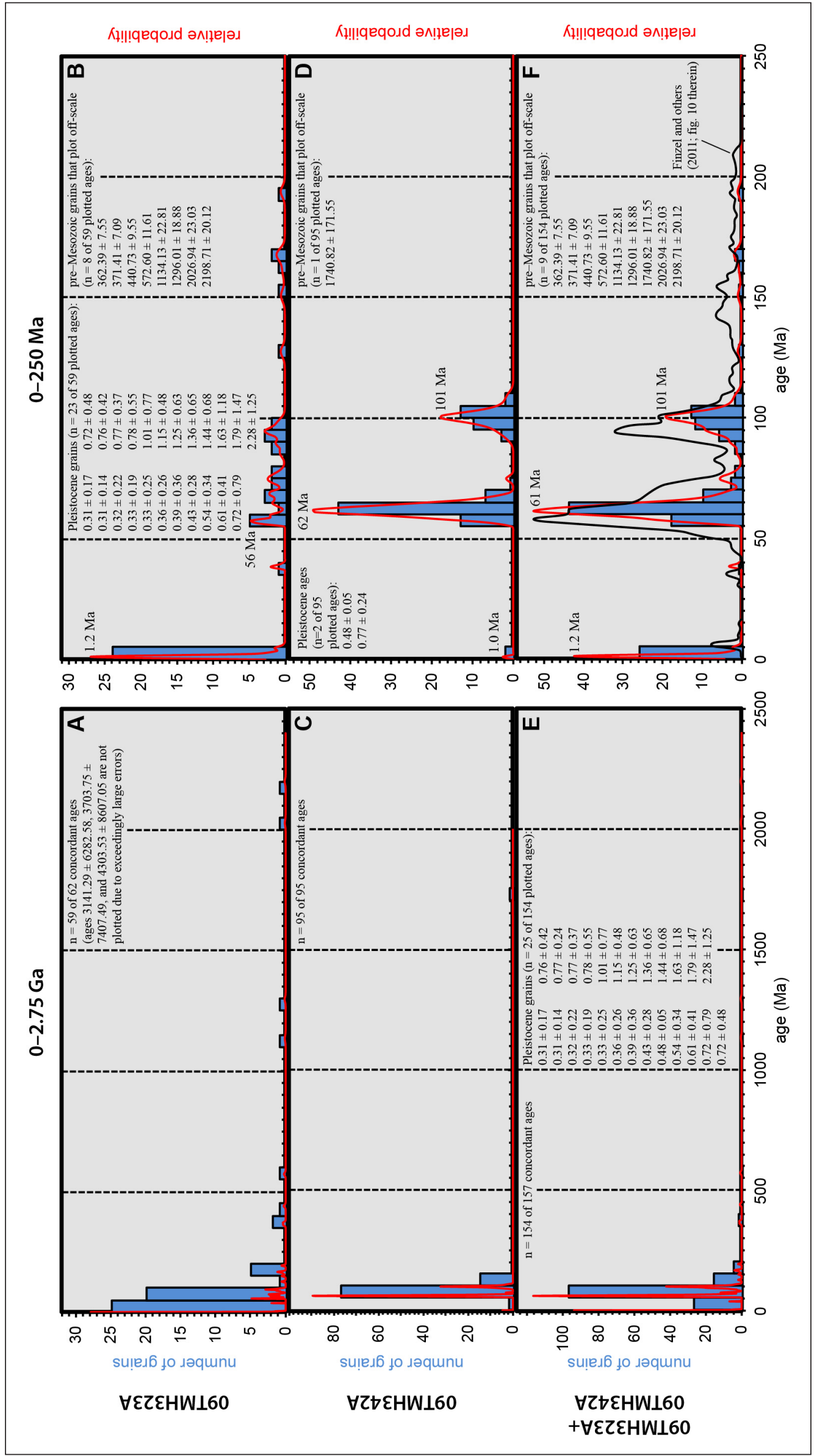

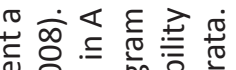

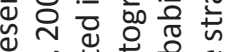

定.

ब

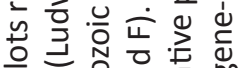

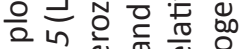

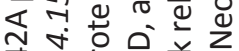

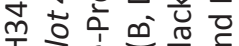

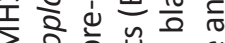

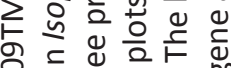

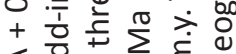

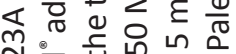

可证

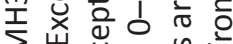

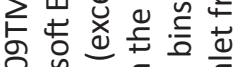

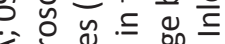

赵.

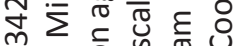

T⿱宀⿻三丨口

政

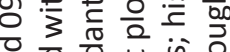

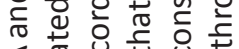

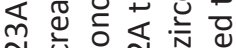

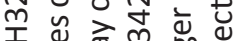

$\sum \sum \frac{0}{2} \stackrel{m}{\frac{1}{5}}$

으의응

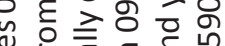

近언

ह 웡

๙

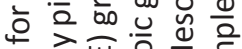

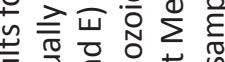

उ 원

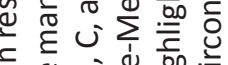

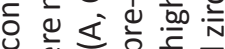

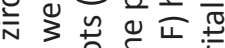

푼

중요

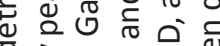

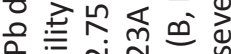

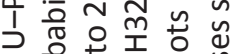

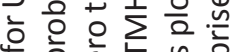

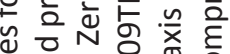

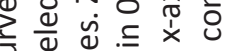

可 $\frac{0}{\pi} \frac{0}{\pi}$

入

घ் ตั

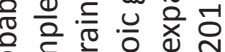

은

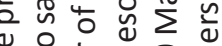

文㐫施员

원

훈

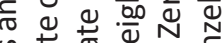

乞 ज政

政

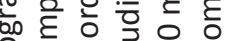

엉은 윤은

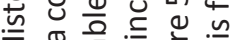
荡

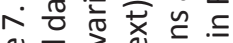
ए त

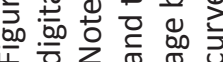


seemingly similar populations, although the number of grains per population - and thus magnitude of correlative age probability peaks - vary notably between the two samples (figs. 7B and D). Dominant probability peaks for 09TMH323A and 09TMH342A occur at 1.2 and $62 \mathrm{Ma}$, respectively (figs. 7A-D). The Pleistocene probability peak at $1.0 \mathrm{Ma}$ in 09TMH342A is minor but significant to this study (fig. 7D).

\section{Regional Context}

The latest Early Cretaceous through Pliocene relative probability curve exhibited by a digitally composited 09TMH323A + 09TMH342A sample (figs. 7E and F) is strikingly similar to a detrital zircon relative probability curve published by Finzel and others (2011; plotted on fig. 7F). The Finzel and others (2011) curve comprises seven digitally composited samples from Paleogene and Neogene Cook Inlet basin-fill strata of the West Foreland Formation and Kenai Group ${ }^{5}$, and is thus ostensibly incapable of exhibiting a Pleistocene-age relative probability peak comparable to the dominant peak of 09TMH323A because the youngest strata those authors sampled are of probable Pliocene age. However, this comparison suggests that the significant pre-Qve detrital component of the volcaniclastic deposits were potentially recycled, at least in part, from the underlying Paleogene and Neogene stratigraphy. The diminished number of Cretaceous and Paleocene ages from 09TMH342A to 09TMH323A (n $=92$ and $\mathrm{n}=21$, respectively) — and increased number of Pleistocene grains ( $n=2$ and $n=23$, respectively)-likely reflects a maturing of the Qve depositional system, with an upsection reduction in recycled West Foreland Formation and Kenai Group sediments and a relative(?) increase in a contemporaneous volcaniclastic detritus component. These trends may record local progressive burial of the underlying stratigraphy as the Qvc depositional system evolved.

\section{Maximum Depositional Age of Qvc}

We employed three methods (adapted from Dickinson and Gehrels, 2009a) for determining maximum depositional ages from the detrital zircon results: (1) youngest single grain age, (2) youngest relative probability curve peak age ( $\mathrm{n} \geq 2$; picked graphically in Microsoft Excel ${ }^{\mathbb{R}}$ ), and (3) weighted mean age of the youngest grain cluster $(n \geq 3)$ with ages that overlap at 2-sigma. The maximum depositional age determinations yielded by these methods are listed in table 2 in order (left to right) of an increasing minimum number of grains (n) required for the result; larger $n$ populations may serve as a proxy for probable increasing reproducibility. Additionally, these results are listed (left to right) by their increasing statistical rigor, increasing likelihood of results to be compatible with depositional age, and decreasing likelihood of results to be coincident with depositional age (Dickinson and Gehrels, 2009a). The farther right a result is in table 2, the more "conservative" that maximum depositional age can be considered.

Sample 09TMH323A (the stratigraphically higher sample) yielded a youngest single grain age of $0.31 \pm 0.14$ $\mathrm{Ma}$, whereas sample 09TMH342A (the stratigraphically lower sample) yielded a $0.48 \pm 0.05 \mathrm{Ma}$ youngest single grain age; however, the reproducibility of these ages may be relatively low, especially in 09TMH342A, which yielded only two Pleistocene-age grains. The youngest probability peaks for 09TMH323A and 09TMH342A occur at 1.2 and 1.0 Ma, respectively, with the former result yielding little to no additional insight into the maximum depositional age of the uppermost sampled strata because a younger, yet more statistically robust and conservative, determination is provided by the youngest 2-sigma cluster method (see below). However, the youngest probability peak of 1.0 Ma for 09TMH342A is the most statistically robust and conservative result (while remaining contextually meaningful) yielded by this study and is thus notable. The most robust and conservative maximum depositional age determination for a single

Table 2. Maximum depositional ages as determined from detrital zircon data presented in this study. Methods and trends listed below are modeled after Dickinson and Gehrels (2009a).

\begin{tabular}{|c|c|c|c|}
\hline \multirow{3}{*}{ Sample } & $\begin{array}{c}\text { Youngest Single Grain } \\
(\mathbf{n}=\mathbf{1})\end{array}$ & $\begin{array}{c}\text { Youngest Probability } \\
\text { Peak }(\mathbf{n} \geq \mathbf{2})\end{array}$ & $\begin{array}{c}\text { Youngest 2 } \sigma \text { Cluster } \\
(\mathbf{n} \geq \mathbf{3})\end{array}$ \\
\cline { 2 - 4 } & \multicolumn{3}{|c|}{$\rightarrow$ Increasingly statistically robust $\rightarrow$} \\
\cline { 2 - 4 } & \multicolumn{3}{|c|}{$\rightarrow$ Increasingly likely to yield result compatible with stratal age $\rightarrow$} \\
\cline { 2 - 4 } & $\rightarrow$ Decreasingly likely to yield result coincident with stratal age $\rightarrow$ \\
\hline 09TMH323A & $0.31 \pm 0.14 \mathrm{Ma}$ & $1.2 \mathrm{Ma}$ & $0.40 \pm 0.09(\mathrm{n}=18)$ \\
\hline 09TMH342A & $0.48 \pm 0.05 \mathrm{Ma}$ & $1.0 \mathrm{Ma}$ & $58.29 \pm 0.53(\mathrm{n}=11)^{*}$ \\
\hline $\begin{array}{c}\text { 09TMH323A }+ \\
\text { 09TMH342A }\end{array}$ & $0.31 \pm 0.14 \mathrm{Ma}$ & $1.2 \mathrm{Ma}$ & $0.45 \pm 0.06(\mathrm{n}=19)$ \\
\hline
\end{tabular}

* geologically insignificant determination

\footnotetext{
5 Kenai Group consists of the Hemlock Conglomerate and Tyonek, Beluga, and Sterling Formations (Magoon and others, 1976; Wilson and others, 2012).
} 
Qvc sample is the youngest 2-sigma cluster result of $0.40 \pm$ $0.09 \mathrm{Ma}$ from 09TMH323A; sample 09TMH342A did not yield a geologically significant youngest 2 -sigma cluster age because the Pleistocene zircon population $(n=2)$ does not meet the minimum cluster size $(\mathrm{n} \geq 3$ ). (Qvc is unequivocally younger than Paleocene because the unit overlies the Oligocene and Miocene Tyonek Formation.) The $0.45 \pm 0.06$ Ma youngest 2-sigma cluster determination for 09TMH323A $+09 \mathrm{TMH} 342 \mathrm{~A}$ is the most statistically rigorous, precise, and conservative maximum age determination yielded by this study.

In summary, the stratigraphically higher sampled interval (09TMH323A) is unlikely to be older than $0.40 \pm 0.09 \mathrm{Ma}$, but may be as young as or younger than $0.31 \pm 0.14 \mathrm{Ma}$. The stratigraphically lower sampled interval (09TMH342A) is unlikely to be older than $1.0 \mathrm{Ma}$, but may be no older than $0.48 \pm 0.05 \mathrm{Ma}$.

\section{CROSS-CUTTING GLACIAL DEPOSITS- QVC MINIMUM DEPOSITIONAL AGE}

A recent study of the surficial geology in the TyonekCapps Glacier area by Reger and others (in preparation) was conducted concurrently with this work. The authors observed granitic, volcanic, and metasedimentary erratics along the volcaniclastic plateau's eroded margins and they associated these glacial deposits with the Upper Chuitna drift of the penultimate glaciation of Marine Isotope Stage (MIS) 4. Therefore, Qvc sedimentation must pre-date glacial advance of MIS 4, which commenced ca. 75 ka (Briner and others, 2005; Matmon and others, 2010). Reger and others (in preparation) also reported field observations and cross-cutting relations indicating that most of the plateau surface was not glaciated during the penultimate glaciation, and was even farther beyond ice limits during the Last Glacial Maximum (associated with MIS 2). The modern plateau margins were thus likely largely established by ice scouring during MIS 4 and subsequently have been further modified by non-glacial surficial processes of latest Pleistocene and Holocene time.

\section{AGE CONSTRAINTS SUMMARY}

New U-Pb zircon ages reported here strongly suggest a Pleistocene age for Qvc, which may be no older than $0.48 \pm$ $0.05 \mathrm{Ma}$. These geochronologic results, in conjunction with field observations of cross-cutting glacial relations, constrain Qve sedimentation to the middle to late Pleistocene but prior to the beginning of MIS $4 \mathrm{ca} .75 \mathrm{ka}$.

\section{SEDIMENTOLOGY}

Qve deposits comprise volcaniclastic detritus, which is defined as volcanogenic clastic material of pyroclastic, autoclastic, and/or epiclastic origin(s) that is transported by any medium or process, deposited by any mechanism, and with or without a subordinate non-volcanogenic clastic component (definition adapted from Fisher, 1961; see summary by Manville and others, 2009). Qve strata largely consist of thickly and crudely bedded, moderately indurated, clast- to matrix-supported, boulder-bearing sandy conglomerate and gravelly sandstone as well as pebbly mudstone. Sand- and gravel-sized clasts are dominantly intermediate(?) composition, dense to vesicular lava fragments and pumiceous to scoriaceous pyroclasts. We describe below four observationbased lithofacies followed by interpreted sediment transport mechanism(s) and depositional environment that reflect a continuum of sedimentologic processes largely dependent on relative concentrations of sediment and water, as well as sediment character (for example, cohesive vs. non-cohesive).

\section{LITHOFACIES DESCRIPTIONS Lithofacies 1-Matrix-Supported Structureless Sandy Conglomerate Description}

The matrix-supported, structureless, granule-boulder, sandy conglomerate of lithofacies 1 (fig. 8) is typically medium to dark gray to gray-brown (wet) to light gray (dry), very thick bedded, poorly sorted, and moderately to well indurated. The supporting matrix is chiefly moderately to poorly sorted, subangular to angular, medium- to very-coarsegrained sandstone with a minor mud component (fig. 8B). The gravel fraction consists of subangular to subrounded granules, pebbles, cobbles, and boulders, with the largest observed in situ clast measuring $3.7 \mathrm{~m}$ (apparent long dimension; fig. 8C). Clasts chiefly comprise dense intermediate(?) volcanic rock fragments, although a notable portion of the granule- to pebble-sized clasts are vesicular. This lithofacies generally comprises the best exposures of Qvc, commonly forming steep to overhanging outcrops with precariously perched meter-sized boulders (figs. 8A, D, and E). Oblique aerial views and outcrop-scale observations suggest strata of this lithofacies typically exhibit tabular bed geometries that are commonly 5-10 m thick and laterally continuous to more than $100 \mathrm{~m}$.

\section{Interpretation}

We interpret deposits of lithofacies 1 as recording deposition from cohesionless debris flows (Vallance, 2005); non-cohesive flows typically have less than 5 percent clay fraction in the matrix (Crandell, 1971; Scott and others, 1995). Lithofacies 1 beds up to $10 \mathrm{~m}$ in apparent thickness may record sedimentation from a single debris flow. Alternatively, Major (1997) demonstrated both experimentally and via observation of natural debris flows that massively thick and structureless deposits may record amalgamated debris flows, or flow pulses during a single event, with indistinguishable amalgamation surfaces. Sedimentologically similar cohesionless volcaniclastic debris-flow deposits commonly lie within many tens of kilometers of continental arc volcanoes. Volcaniclastic deposits comparable to lithofacies 1 have been (1) inferred in the geologic record (for example, Smith, 1986, 1991; Scott, 1989; Major and others, 2005; Zernack and others, 2009), (2) generated during historical debris-flow events (for example, Pierson and Scott, 1985; Scott, 1988; Pierson and others, 1990; Major and others, 2005), and (3) reproduced in large-scale flume experiments (for example, Iverson, 1997; Major, 1997). 


\section{Lithofacies 2-Clast-Supported Structureless to Crudely Organized Conglomerate \\ Description}

The clast-supported, structureless to crudely organized granule-cobble conglomerate of lithofacies 2 (fig. 9) is typically medium to dark gray with locally conspicuous redbrown-weathering clasts, thick to very thick bedded, poorly to moderately sorted, and moderately indurated. Clasts are dominantly subangular to subrounded pebbles and cobbles
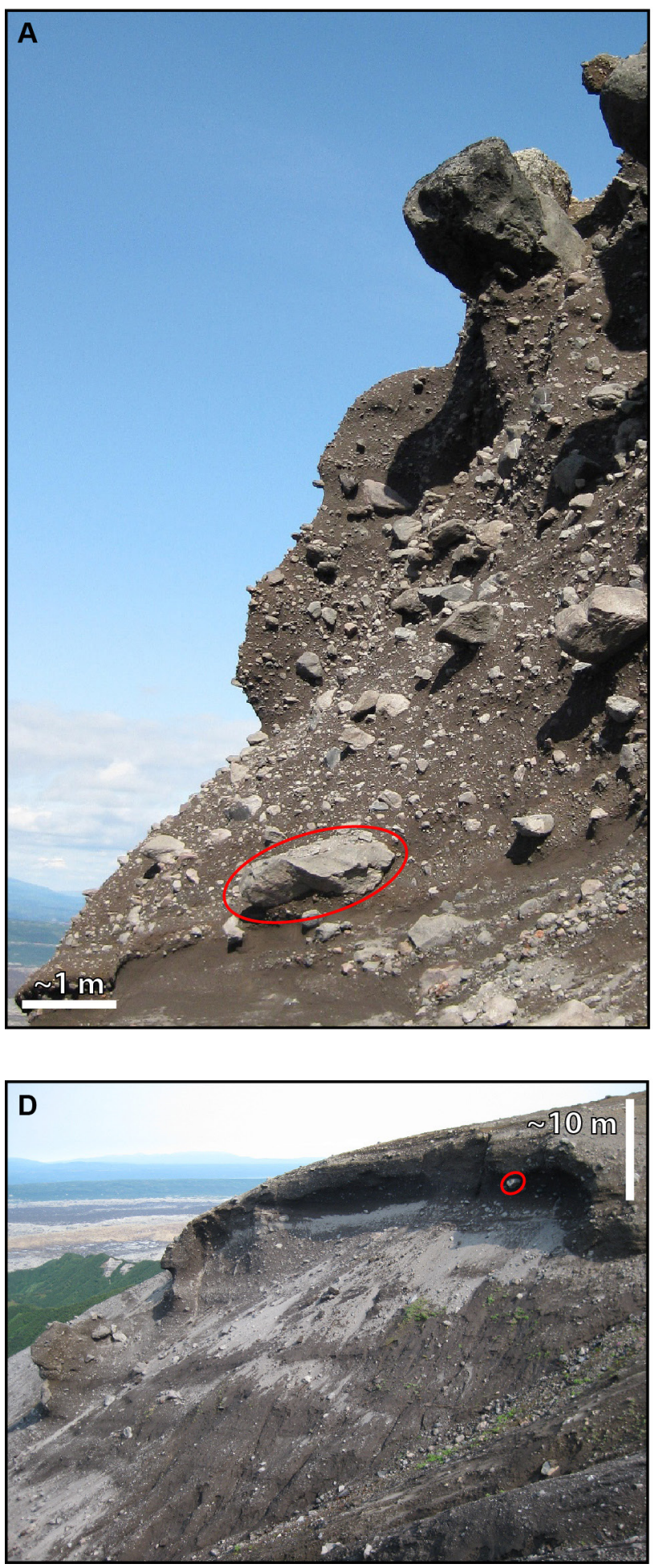

(fig. 9A) comprising dense to vesicular to (subordinate) pumiceous/scoriaceous volcanic rock fragments; morphologically and lithologically similar boulders to greater than $1 \mathrm{~m}$ are locally observed in channel-fill deposits (figs. 9B-D). The matrix consists of poorly sorted, subangular to angular, medium- to very-coarse-grained sandstone that is lithologically and texturally similar to the matrix of lithofacies 1. Outcropbased observations along exposures extending laterally for tens of meters indicate lithofacies 2 commonly exhibits
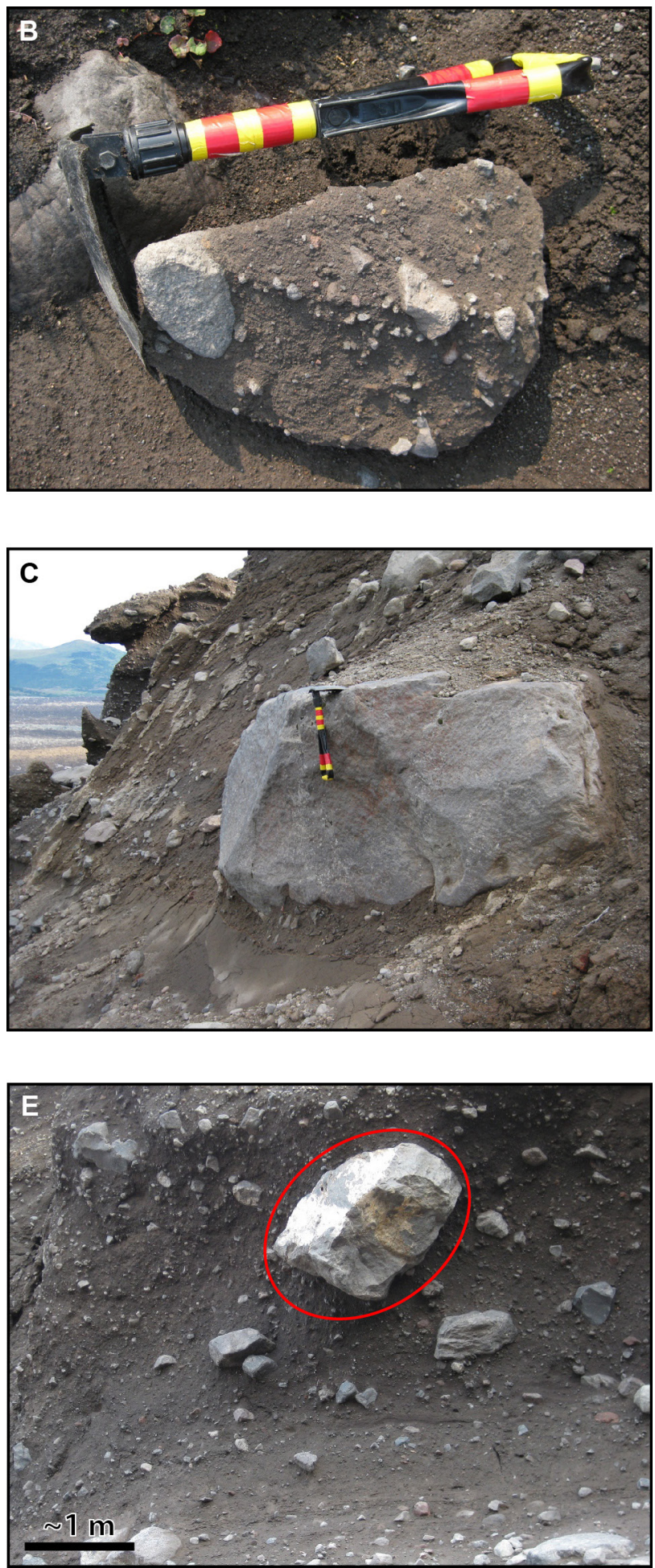
scoured basal contacts and forms fill deposits in typically low-aspect-ratio, decimeter-scale relief scours and channels (figs. 9B-D and F). The fill deposits locally transition laterally into thinner, finer-grained, and somewhat-better-sorted deposits immediately beyond scours and channels (figs. 9D and F). A somewhat weakly developed alignment of clasts in pebble- to cobble-rich lithofacies 2 exposures locally yields crude bedding-parallel organization (fig. 9E), but it is unclear whether all such deposits represent lateral correlatives of the disorganized scour and channel fills. Several exposures also indicate this lithofacies locally transitions laterally and upsection into lithofacies 1 (figs. 9B, C, and F).

\section{Interpretation}

We interpret deposits of lithofacies 2 as recording deposition from cohesionless pebble- and cobble-rich channelized to overbank debris flows. We suspect the crudely organized deposits of lithofacies 2 that are not directly observed to be associated with the channelized deposits may represent lateral equivalents to the channel fill, potentially recording either deposition along debris-flow margins where coarse clasts (such as cobbles) are commonly concentrated, producing matrix-poor, and potentially better sorted and organized deposits when compared to flow interiors (Major, 1997, 1998; Vallance, 2000, 2005), or more broad, sheet-like overbank

Figure 8. Field photographs of lithofacies 1 (matrix-supported, structureless, sandy conglomerate). Photographs by T.M. Herriott.

A. Approximately 10-m-thick, boulder-bearing bed with $1.6 \mathrm{~m}$ (apparent long axis) boulder (circled in red) near the deposit's base and several boulders larger than 1 $\mathrm{m}$ cropping out precariously along the photo skyline at right.

B. Float block depicting representative sandstone matrix and subangular to subrounded, dense to vesicular, lava pebble-size fraction. Shovel is $45 \mathrm{~cm}$ long.

C. Boulder at base of conglomerate bed is $3.7 \mathrm{~m} \times 1.3 \mathrm{~m}$. This is the largest boulder observed in place during this study, but several larger boulders (although the same order of magnitude in linear dimensions) occur in slope debris at the base of similar outcrop belts along the plateau perimeter. Faint horizontal stratification in the underlying thick-bedded, coarse-grained sandstone (lithofacies 3 ) is apparently deflected (concave up) by the overlying boulder, which likely exceeds $15,000 \mathrm{~kg}$. Shovel is $45 \mathrm{~cm}$ long.

D. View eastward of tens-of-meters-thick succession of predominantly lithofacies 1 strata exposed along the northern rim of the volcaniclastic plateau. Depositional units of this lithofacies commonly appear to be $5-10 \mathrm{~m}$ thick. Boulder (circled in red for scale) is approximately $1.5 \mathrm{~m}$ (apparent long axis) and the dark gray deposit in which it lies is approximately 7 $\mathrm{m}$ thick; this same boulder is circled in $\mathrm{E}$.

E. Outcrop-scale view of lithofacies 1 deposit along the northern plateau edge (same boulder as circled in D). deposits from dilute debris flows or sediment-rich hyperconcentrated flows. Our interpretations of channelized debris flow and probable associated overbank mass flow for lithofacies 2 are generally consistent with those made by Zernack and others (2009) for lithologically and texturally similar volcaniclastic facies at Mount Taranaki (Egmont volcano), New Zealand (also Scott, 1988; Major and others, 2005).

\section{Lithofacies 3-Faintly Horizontally Stratified Gravelly Sandstone \\ Description}

The faintly horizontally stratified gravelly sandstone of lithofacies 3 (fig. 10) is typically medium to dark gray to dark gray-brown (wet) to medium gray (dry), thick to very thick bedded (fig. 10A), moderately to poorly sorted, and moderately indurated. The dominant sand fraction is angular to subangular and medium to very coarse grained (fig. 10B), with subordinate granules consisting of subangular to subrounded pumiceous and scoriaceous detritus and dense to vesicular lava fragments. Conspicuous bedding-parallel stringers of orange-yellow-weathering pumiceous granules (figs. 10C and D) and minor variability in vertical distribution of grain size along subtly expressed bedding-parallel horizons (figs. 10A and $\mathrm{C}-\mathrm{F}$ ) - in addition to silty partings that are locally observed in thinner-bedded intervals of this lithofacies (fig. 10E) - serve to impart the faint horizontal stratification in lithofacies 3. Furthermore, "floating" subangular to subrounded pebbles (fig. 10C) and cobbles locally create discontinuous, bedding-parallel gravelly horizons that further establish faint intra-bed stratification. Decimeterscale, pebble-rich lenses are also locally noted (fig. 10F). Our observations indicate that this lithofacies generally exhibits tabular bed geometries along bedding-parallel outcrops extending for tens of meters, but is locally observed to have eroded tops with channels that are infilled with lithofacies 2 deposits (figs. 9B-D and F).

\section{Interpretation}

We interpret deposits of lithofacies 3 as recording deposition from hyperconcentrated flows (Beverage and Culbertson, 1964; Pierson, 2005), exhibiting characteristics consistent with hyperconcentrated-flow deposits described by, for example, Pierson and Scott (1985), Smith, (1986), Scott (1988), Pierson and others (1990, 2009), Smith and Lowe (1991), Cronin and others (2000), Procter and others (2009), and Zernack and others (2009). Hyperconcentrated flows have been suggested to be particularly efficient at transporting sand-sized particles (Pierson and Scott, 1985; Pierson, 2005), producing thick, structureless to faintly stratified, coarse-grained sandstone to gravelly sandstone. Furthermore, "pumice trains" (fig. 10D) are reported by Zernack and others (2009) in association with deposits of interpreted hyperconcentrated flow origin that form thickly bedded, broad depositional sheets up to $2.5 \mathrm{~km}$ in lateral extent at Mount Taranaki. Vallance (2000) suggested silty partings (fig. 10E) in otherwise massive sandstone of probable hyperconcentrated flow origin reflects post-deposition dewatering, and field observations of active flows by Cronin 
and others (2000) are in agreement (also Pierson and others, 2009). Finally, Pierson and Scott (1985) reported small, gravelly lenses in recently emplaced hyperconcentrated-flow deposits at Mount St. Helens, once again similar to observations made during this study (fig. 9F).

\section{Lithofacies 4-Structureless Pebbly Mudstone Description}

The structureless pebbly mudstone of lithofacies 4 (fig. 11) is typically orange-tan to light gray-brown (figs.
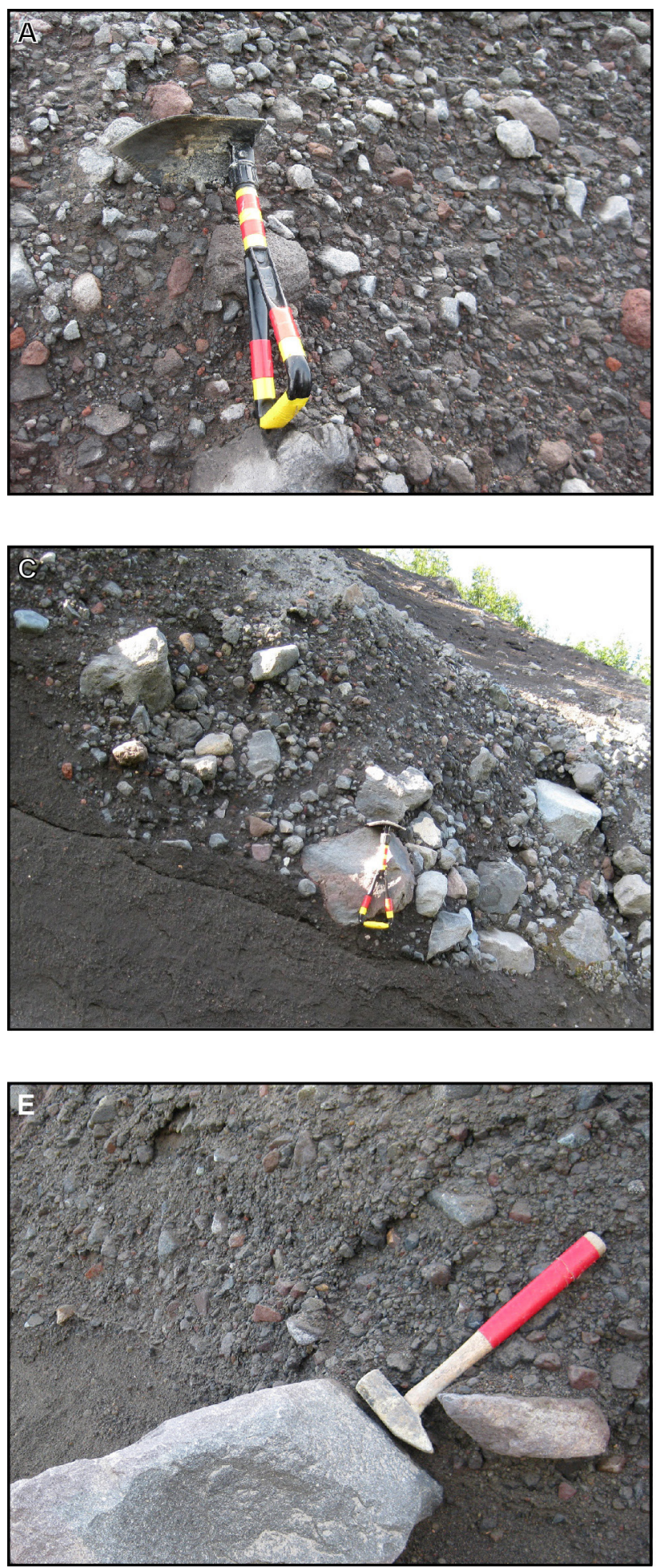

$11 \mathrm{~A}$ and B), thick to very thick bedded (fig. 11B), weakly indurated, and dry exposures exhibit hackly fracturing (figs. $11 \mathrm{C}$ and $\mathrm{D})$. The muddy matrix component of this lithofacies is commonly very clay rich (figs. $11 \mathrm{C}-\mathrm{E}$ ), and in some exposures clay-sized material likely comprises the bulk of the deposits (figs. 11C and D). However, some lithofacies 4 exposures exhibit a prominent, albeit subordinate, pebblesized clast component chiefly comprising subangular to subrounded, dense to vesicular lava fragments (fig. 11E). Subrounded to rounded granitic and metavolcanic pebbles,
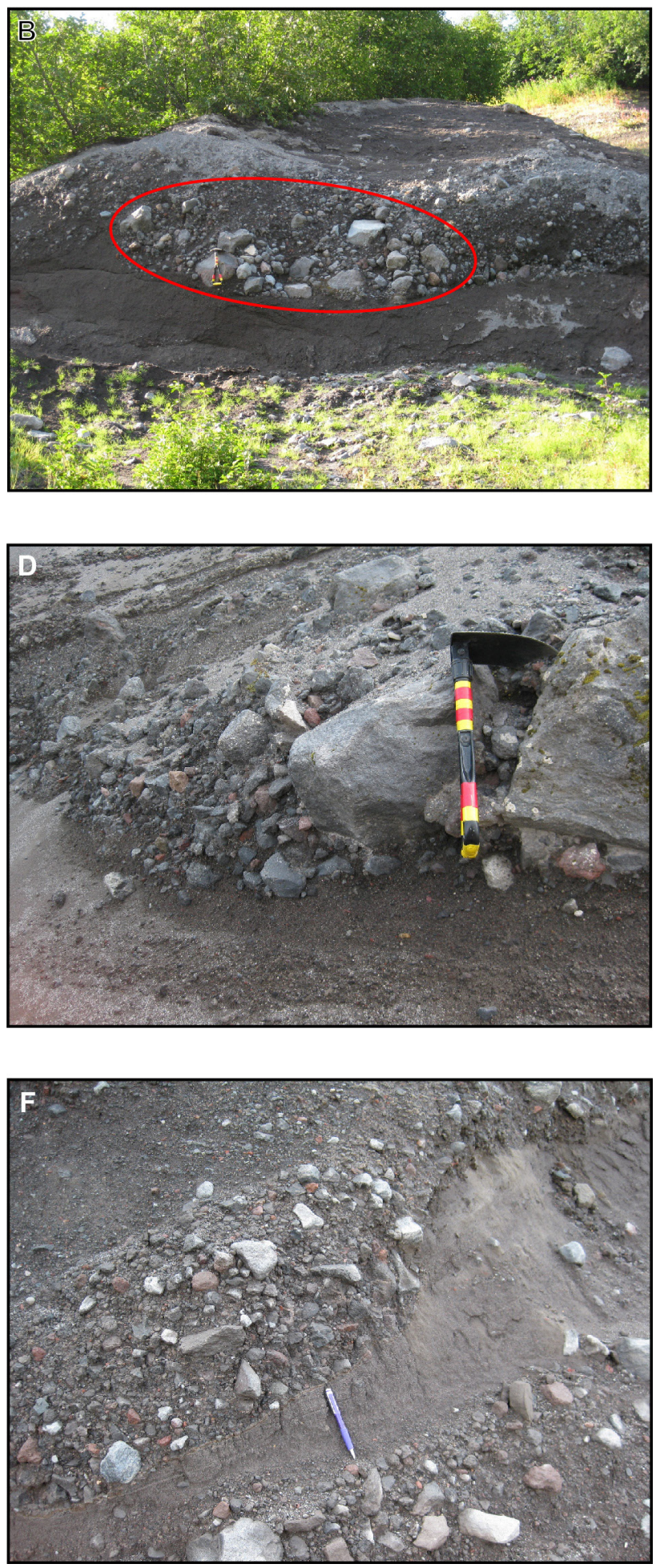
cobbles, and boulders to $\sim 75 \mathrm{~cm}$ (apparent long dimension; figs. 11B and F) are locally observed in lithofacies 4 and are unique in being the only non-volcanic clasts observed in Qve during this study. Tabular bed geometries are observed along bedding-parallel outcrops extending more than 100 $\mathrm{m}$. Additionally, we only observed this mudstone facies in the northwestern part of the volcaniclastic plateau, and the apparently tens-of-meters-thick package of clayey strata in figure $11 \mathrm{~A}$ may not be laterally continuous for more than several kilometers in east-west extent; however, generally poor exposure to the east hampers efforts to definitively determine the lateral distribution of this lithofacies.

\section{Interpretation}

We interpret deposits of lithofacies 4 as recording deposition from cohesive debris flows (Vallance, 2005). The relatively high clay content of the flows evidently rendered a matrix yield strength capable of transporting large boulders via suspension (fig. 11F) (Pierson, 2005). The metavolcanic and granitic clasts are unique to this lithofacies and provide the record of a source for non-volcanic detritus that was entrained during transport. Similar lithofacies in both modern and ancient continental margin volcanic arc settings have been interpreted by other workers as recording deposition from cohesive debris flows that commonly transform from debris avalanches (for example, Glicken, 1986; CarrascoNuñez and others, 1993; Scott and others, 1995; Vallance

Figure 9. Field photographs of lithofacies 2 (clast-supported, structureless to crudely organized conglomerate). Photographs by T.M. Herriott.

A. Commonly observed texture and fabric of nonchannelized lithofacies 2 . Shovel is $45 \mathrm{~cm}$ long.

B. Outcrop-scale exposure of boulder-bearing lithofacies 2 (red circle) that lies in a low-aspect-ratio scour and transitions laterally and upsection into matrix-supported lithofacies 1 . Sandstone and pebbly sandstone of lithofacies 3 crop out between the vegetated slope (foreground) and the shovel's handle ( $45 \mathrm{~cm}$ long).

C. Detailed view of lithofacies 2 scour fill, with shovel ( 45 $\mathrm{cm}$ long) propped on the same boulder as in B.

D. Exposure of poorly sorted, boulder-bearing lithofacies 2 , which is underlain by lithofacies 3 . This low-relief fill deposit grades laterally into a non-boulder-bearing deposit of lithofacies 2 toward left of photo, and may be the record of an obstacle-related scour. Shovel is 45 $\mathrm{cm}$ long.

E. Lithofacies 2 exposure that exhibits a somewhat greater degree of sorting and crude bedding-parallel organization. Hammer is $38 \mathrm{~cm}$ long.

F. Channel scour (immediately above 14-cm-long pencil) overlain by lithofacies 2 pebble and cobble conglomerate fill that grades upsection into a pebbly variety of probable lithofacies 1 and laterally into thinner and somewhat-finer-grained lithofacies 2 . Once again, similar to the scours of $B, C$, and D, lithofacies 2 here is underlain by faintly horizontally stratified sandstone of lithofacies 3. and Scott, 1997; Waythomas, 2007; Zernack and others, 2009). This lithofacies - although fundamentally different in many respects from the three clay-poor lithofacies described above - remains consistent with mass-flow sedimentation in an arc setting, with deposition at a site likely lying within tens of kilometers of a volcanic edifice.

\section{SEDIMENTOLOGY DISCUSSION Volcanogenic Sediment-Laden Flows-Lithofacies 1-4 as Lahar Deposits}

Lithofacies recognized in Qvc are, in this study, chiefly attributed to laharic transportation and depositional processes (fig. 12). Lithologically, texturally, and stratigraphically similar deposits have been observed throughout the world near stratovolcanoes at modern, convergent continental margin arc settings (for example, Pierson and others, 1990; Cronin and others, 2000; Major and others, 2005) and are also inferred in the Cenozoic rock record (for example, Smith, 1986, 1991; Scott, 1989; Herriott, 2006; Zernack and others 2009). We underscore that lahars: (1) comprise sediment-laden flows that span part of a sediment-water flow type continuum, (2) are generated by a variety of mechanisms that are common in continental volcanic arc environments, (3) commonly undergo flow transformations during transport if cohesionless, and (4) generate deposits with sedimentologic features remarkably similar to those observed during this study (see fig. 12 and Possible Modern Depositional Site Analogues). Ultimately, laharic processes provide a framework that ties our observations and lithofacies interpretations of Qve strata into a geologic context characterized by proximity to explosive arc volcanism and recurring hyperconcentrated- and debris-flow events. We include a brief introduction to lahars and lahar processes in appendix $\mathrm{C}$, and also refer readers to reviews of lahars and associated volcaniclastic processes: Smith (1986, 1991), Smith and Lowe (1991), Vallance (2000, 2005), Pierson (2005), and Manville and others (2009).

In this general context of laharic processes in continental arc settings, the geographic proximity and documented Pleistocene eruptive activity of the Spurr volcanic complex (Nye and Turner, 1990) 20-25 km west of the volcaniclastic plateau suggests a genetic relation, although the Holocene eruptive vents of modern Mount Spurr volcano are ostensibly too young to have produced the volcaniclastic material of Qvc. However, these young vents at Spurr lie within the caldera of an ancestral Mount Spurr (Nye and Turner, 1990); the growth cycle of this stratovolcano, as reported by Nye and Turner, began prior to $0.255 \pm 0.052 \mathrm{Ma}\left({ }^{40} \mathrm{~K}-{ }^{40} \mathrm{Ar}\right.$ age $)$, continued through $0.058 \pm 0.018 \mathrm{Ma}\left({ }^{40} \mathrm{~K}-{ }^{40} \mathrm{Ar}\right.$ age $)$, and was terminated by a caldera-forming sector collapse event likely occurring in latest Pleistocene to earliest Holocene time (Waythomas, 2007). Therefore, the documented eruptive history of ancestral Mount Spurr may in part overlap with deposition of Qvc (see Age of Qvc, above). Further, volcanism in the area likely extends well into the early Pleistocene, as indicated by a lava flow lying $\sim 5 \mathrm{~km}$ northeast of Mount Spurr that yielded $\mathrm{a} \geq 2.08 \pm 0.20 \mathrm{Ma}^{40} \mathrm{~K}-{ }^{40} \mathrm{Ar}$ age (Nye and Turner, 1990). We preliminarily suggest that ancestral Mount Spurr may have been a source for the volcaniclastic material 
comprising Qvc; however; further investigation is warranted if a definitive link, rather than a chiefly geographically and temporally circumstantial one, between Qvc and ancestral Mount Spurr is to be established.

The Qvc depositional system was likely prone to flashy discharge of water floods in a catchment headed at or near a stratovolcano replete with abundant, unconsolidated volcaniclastic detritus readily susceptible to transport to a
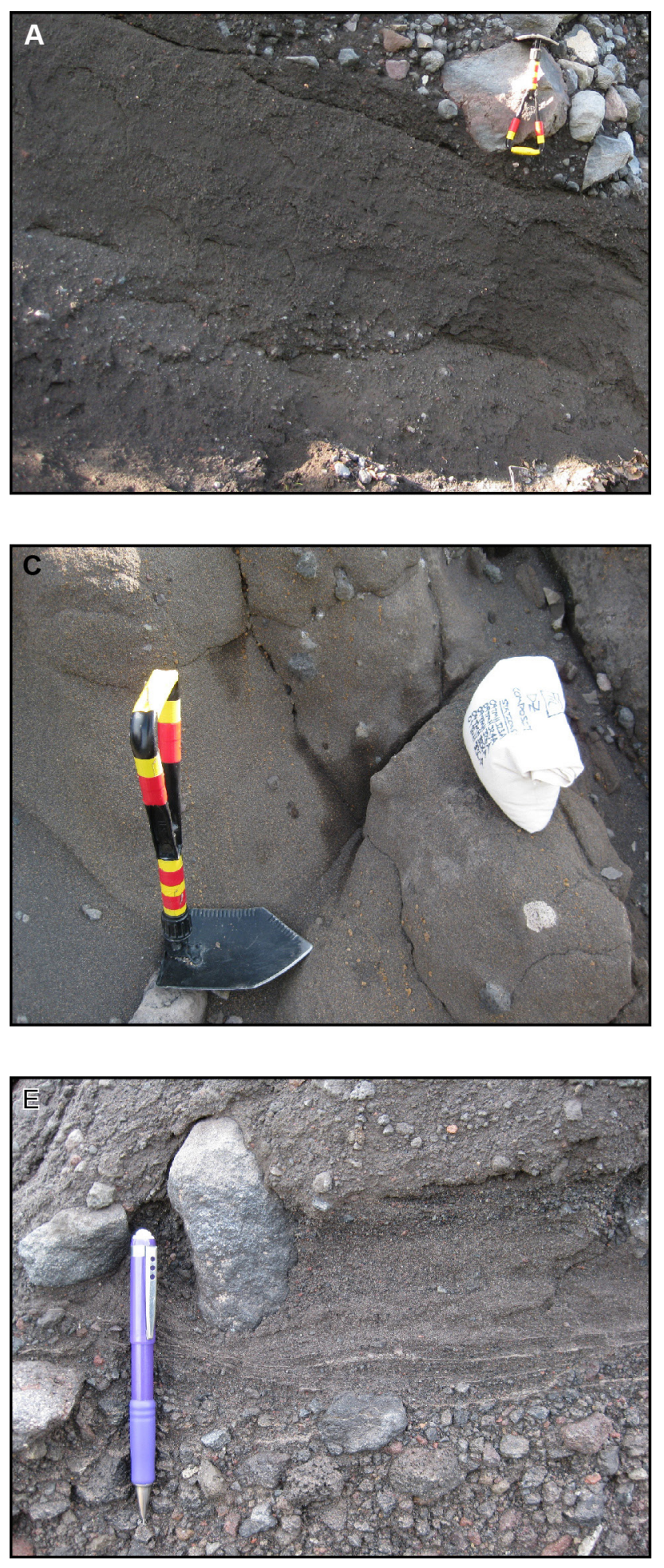

depositional site that likely persisted for several hundred thousand years at what is now the volcaniclastic plateau. Lithofacies 1-3 are attributed to bulking of water floods to hyperconcentrated and debris flows; clay-rich cohesive debris flows (lithofacies 4) also occurred, but are not nearly as ubiquitous as the non-cohesive deposits, and may record volcano-hydrologic event(s) of profound and fundamentally different origins (for example, sector collapse; see appendix C).
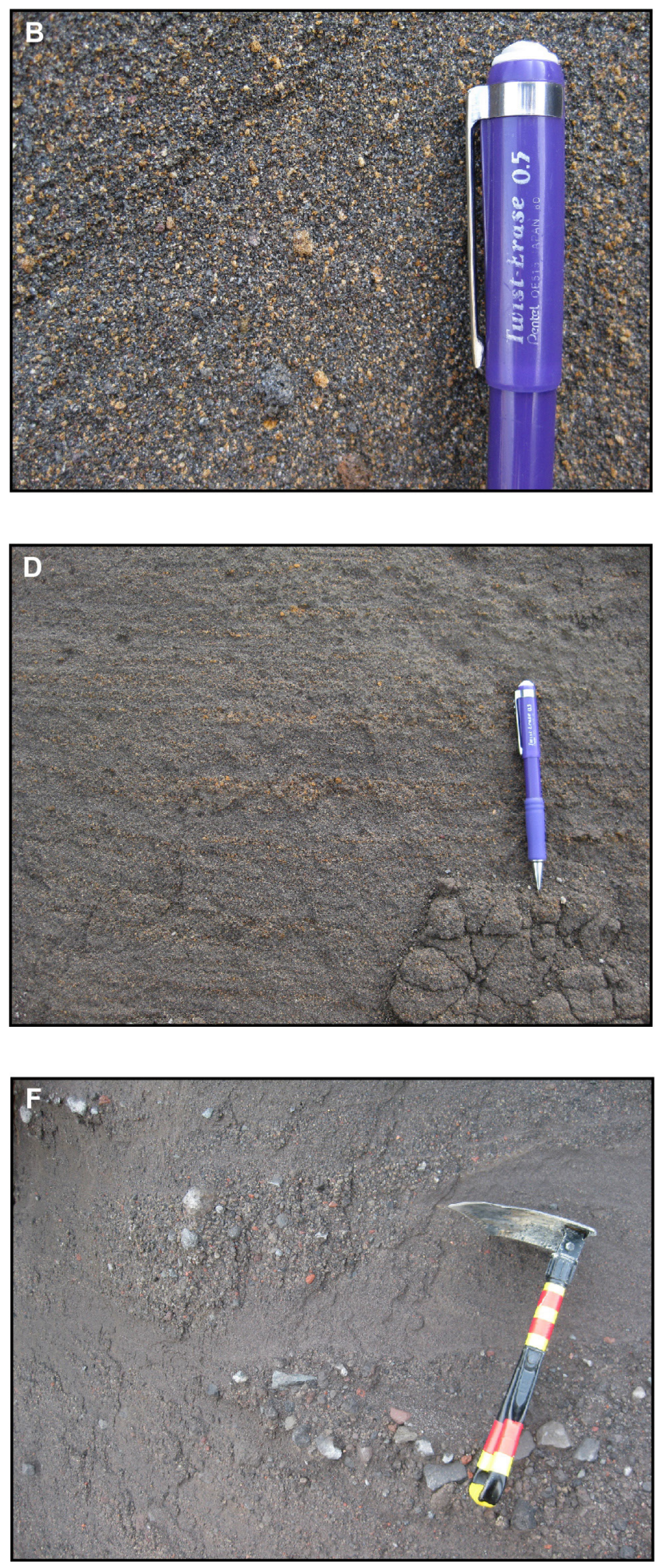
Lithofacies 1-3 of this study are compatible with, but not necessarily limited to, being distal-proximal-lateral facies variations of non-cohesive lahars that have a propensity to bulk or dilute in time and space during a single flow event (Cronin and others, 2000). We also suspect that normal stream flow, and thus classic fluvial processes and associated deposits, were likely more common throughout Qvc time than our field observations suggest. Many potential modern analogues to the Qvc depositional system are principally characterized by background fluvial processes (Manville and others, 2009). The Qvc depositional system may have been similarly subjected to brief episodes of volcanism and lahar generation with longer-lived inter-eruptive periods when background sedimentation rates and styles were reestablished and lowflow fluvial processes dominated (Smith, 1991; Major and others, 2000). The apparent dearth of fluvial deposits in Qvc may reflect poor preservation potential due to removal by relatively erosive hyperconcentrated flows and/or are simply underrepresented due to their probable thinner-bedded and better-sorted character that results in a potentially diminished propensity to crop out. Further study of the succession may highlight a greater occurrence of fluvial deposits, and we suspect that some of the chaotically deformed strata near and southwest of peak 2780 may be of more typical fluvial (dilute stream flow) origin.

Although we confidently interpret lithofacies 4 as recording deposition of cohesive debris flows, such deposits in volcanic environments are commonly sourced from

Figure 10. Field photographs of lithofacies 3 (faintly horizontally stratified, gravelly sandstone). Photographs by T.M. Herriott.

A. Commonly observed texture and fabric of lithofacies 3. Shovel ( $45 \mathrm{~cm}$ long) is placed on boulder in overlying deposit of lithofacies 2.

B. Detailed view of sorting and angular to subangular grain morphology of sand-sized grains of lithofacies 3 sandstone. Orange-yellow-weathering sand and granules are likely weathered pumice. Pencil is $11 \mathrm{~mm}$ wide.

C. Pebble-bearing lithofacies 3 deposit exhibiting faint horizontal stratification; bedding is parallel to the pebble-rich cleft at photo's upper right.

D. Conspicuous stringers of orange-yellow-weathering pumiceous granules and sand commonly define faint horizontal stratification in lithofacies 3. Indistinct, seemingly low angle cross-stratification occur here as well, potentially recording transitional flow conditions. Pencil is $14 \mathrm{~cm}$ long.

E. Thinner-bedded lithofacies 3 at center of photo exhibits several thin, silty partings and overlies clast-supported pebble conglomerate of lithofacies 2 . The overlying conglomeratic sandstone is lithologically transitional, but may be a coarser-grained and less-well-organized example of lithofacies 3. Low-angle cross-lamination may be preserved $\sim 10 \mathrm{~cm}$ to the right of the pencil immediately above the pebble conglomerate.

F. Pebble-rich, gravelly lenses are encased in a larger body of faintly stratified sandstone. hydrothermally altered volcanic edifice rocks mobilized during sector collapse (Vallance and Scott, 1997; appendix C); cohesive lahars typically record a first-order event in the growth cycle of stratovolcanoes (Zernack and others, 2009). Because of the profound implications of sector-collapserelated debris avalanches and associated cohesive lahars at stratovolcanoes, we suggest further investigation would be necessary to better understand the context and significance of the clayey debris-flow deposits of lithofacies 4.

\section{POSSIBLE MODERN DEPOSITIONAL SITE ANALOGUES}

Many lahar-prone depositional sites that occur in continental margin volcanic arc settings lie along broad river valley floodplains or on more areally extensive alluvial plains (compare Smith, 1987), despite the common preponderance of lithofacies that are more typical of alluvial fans in non-volcanic settings. However, some sites prone to laharic sedimentation likely meet the morphological criteria that define more proximal but still relatively-low-gradient alluvial fans (fan-shaped in plan-view, concave-up radial profile, convex-up transverse profile; Nilsen, 1982). Pierson (1995) noted that observations of historic debris flows at snow-clad volcanoes indicate that initial wholesale deposition of large volumes of lahar-transported sediment occurs $\sim 15-75 \mathrm{~km}$ from the source volcano along reaches characterized by relatively-low-gradient fans or channels of less than 0.010 $\left(0.57^{\circ}\right)$ but ranging up to $0.020\left(1.15^{\circ}\right)$. Rapid deposition of sediment from debris flows often yields hyperconcentrated flows that travel well beyond associated debris-flow deposits, extensively inundating floodplains along more distal channel reaches (Scott, 1988).

Several lahar-prone depositional sites associated with eruptions of the past several decades may represent modern analogues for Qvc, including: (1) the Armero "debris fan" at Nevado del Ruiz volcano, Columbia (fig. 29 of Pierson and others, 1990), (2) Bamban and Pasig-Potrero rivers alluvial fans at Mount Pinatubo volcano, Philippines (fig. 18 of Pierson and others, 1996), (3) South Fork Toutle River valley floodplain at Mount Saint Helens volcano, Washington (fig. 27.5A of Major and others, 2005), and (4) Drift River valley floodplain at Redoubt Volcano (figs. 26 and 28 of Schaefer, 2012; figs. 6A, 9, and 12 of Waythomas and others, 2012). The first two examples comprise low-gradient fans and the latter two are relatively broad (kilometer-scale) floodplains hosted in mountainous regions characterized by moderate to steep topographic relief.

Lithofacies, site scale, and overall geologic context of the lahar-prone Armero "debris fan" (Lowe and others, 1986; Naranjo and others, 1986; Pierson and others, 1990) likely render it an especially relevant analogue in the context of this paper. On November 13, 1985, a relatively small eruption of hot pyroclastic material melted snow and ice near the summit of Nevado del Ruiz, creating a series of lahars that bulked as they surged down deeply incised channels draining the flanks of the volcano. The Armero site has a depositional gradient of $0.011\left(0.63^{\circ}\right)$ (at the village of Armero; Pierson, 1995 ) and the fan head lies at the mouth of the confined Rio 

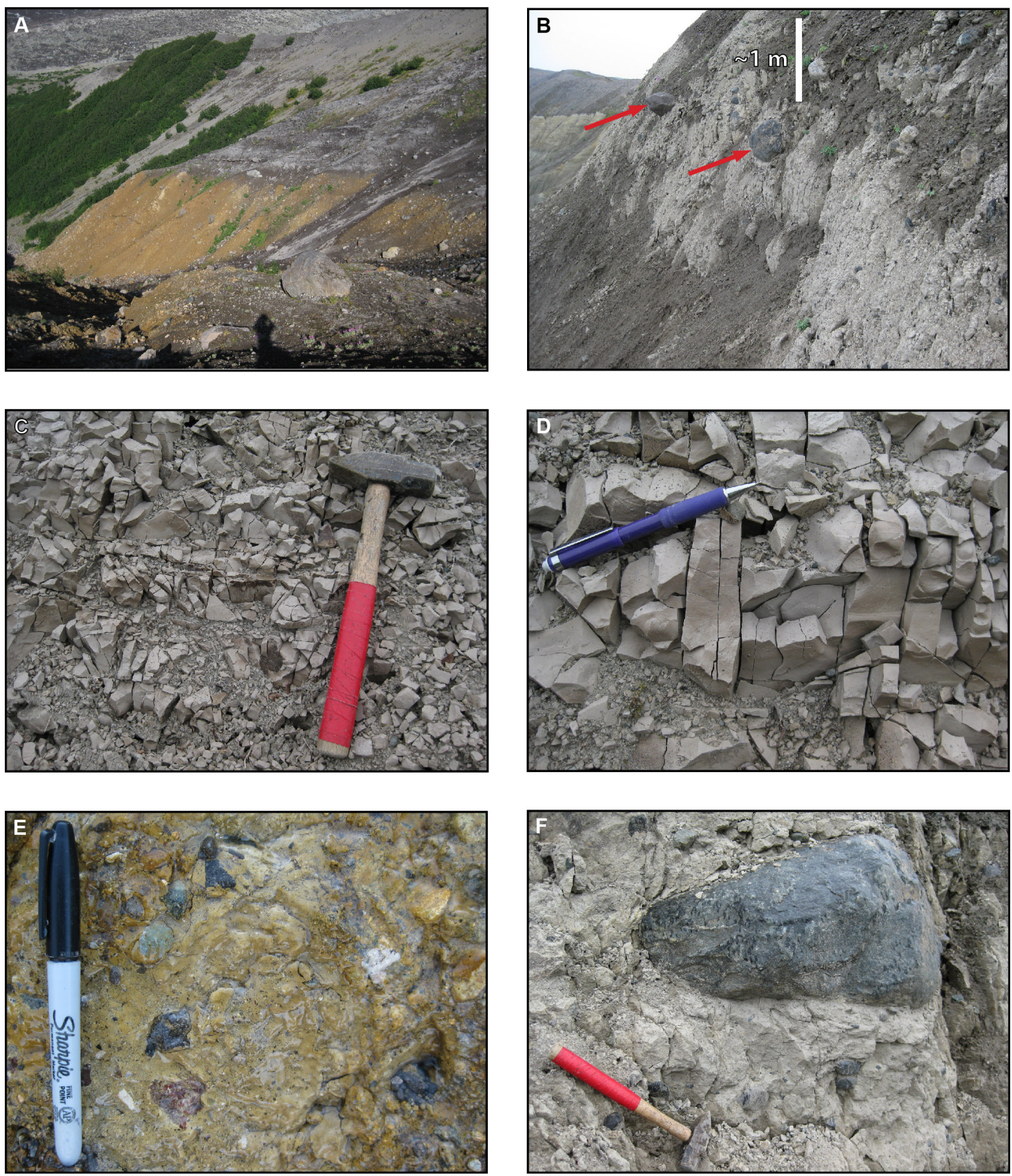

Figure 11. Field photographs of lithofacies 4 (structureless, pebbly mudstone). Photographs by T.M. Herriott.

A. The apparently more-than-10-m-thick orange-tan-colored interval below the photo's centerline comprises lithofacies 4 and is notably clay rich.

B. A typical exposure of very-thick-bedded, boulder-bearing clayey mudstone. Red arrows point to two subrounded boulders with a $>50 \mathrm{~cm}$ diameter.

C. Hackly fracturing character was commonly observed in gravel-poor occurrences of this lithofacies. Hammer is $38 \mathrm{~cm}$ long.

D. Detailed view of hackly fracturing style in very-well-sorted exposure of lithofacies 4 . Pencil is $14 \mathrm{~cm}$ long.

E. Poorly sorted, pebbly, clay-rich deposit with seep-water flowing over the outcrop surface. Marker is $14 \mathrm{~cm}$ long.

F. A metavolcanic boulder, in addition to more abundant cobble- and pebble-sized clasts (some of granitic lithologies) is suspended in a mudstone matrix. Our observations suggest non-volcanic lithologies are limited to this lithofacies. 
Azufrado/Lagunillas canyon, where the eruption-triggered lahars debouched and inundated an area of $\sim 34 \mathrm{~km} 2$ (Pierson and others, 1990). Debris- and hyperconcentrated-flow deposits lithologically similar to those observed during this study aggraded to an estimated average thickness of $1.5 \mathrm{~m}$ (Lowe and others, 1986). Tragically, within hours of the eruption, these lahars inundated the town of Armero with flow depths up to $5 \mathrm{~m}$, and more than 20,000 of the village's nearly 29,000 residents lost their lives (Pierson and others, 1990).
Two lahar events larger than the 1985 flows occurred in 1595 and 1845 (Thouret and others, 1990), suggesting that substantial, episodic sedimentation events and centennial-scale lahar recurrence intervals at the Armero fan may represent the rule rather than the exception.

Although the Armero site is seemingly analogous to the Qvc depositional system, it remains unclear whether Qve strata are the record of alluvial fan versus floodplain deposition. Alluvial depositional systems are inherently

\section{FLOW TYPES, SEDIMENT SUSPENSION MECHANISMS, AND DEPOSIT CHARACTERISTICS OF SEdiment-WATER Flows in VolCANic SetTingS}

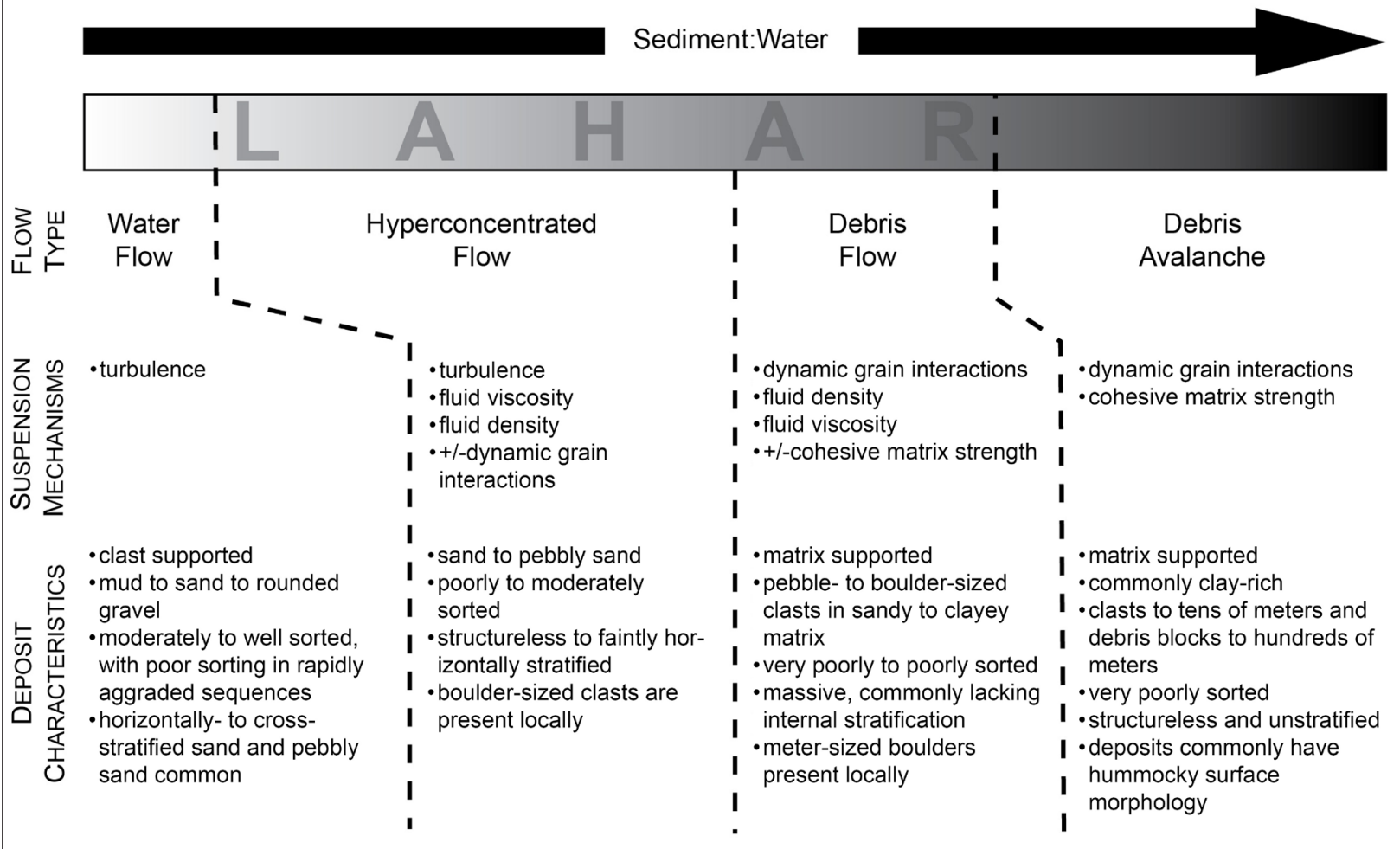

Figure modified from Smith and Lowe, 1991

Water flow parameters from Smith and Lowe, 1991; Pierson, 2005; Zernack and others, 2009

Hyperconcentrated flow parameters from Vallance, 2000; Pierson, 2005; Zernack and others, 2009

Debris-flow parameters from Vallance, 2000, 2005; Zernack and others, 2009

Debris avalanche parameters from Smith and Lowe, 1991; Glicken, 1996; Iverson, 2005

Figure 12. Sediment-water continuum flow diagram modified from Smith and Lowe (1991). Water flow, or dilute stream flow, behavior is dominated by water that acts as a Newtonian fluid with no yield strength and sediment is suspended by fluid turbulence (Pierson, 2005). Increasing sediment concentration ultimately produces hyperconcentrated-flow behavior that is also dominated by a turbulent, although somewhat dampened, fluid phase with the lower transition threshold occurring when water plus fines begins to act as a non-Newtonian fluid (that is, it has a yield strength; Pierson and Costa, 1987). Pierson (2005) also notes that this is the point along the sediment-water continuum where sand concentrations in a flow begin to increase dramatically, allowing hyperconcentrated flows to transport, in suspension, copious quantities of sand. Transition across the lower threshold of debris flow occurs where solid mechanical phenomena (such as grain-ongrain interactions) begin to play a prominent role in sediment suspension of gravel-sized particles, but fluid mechanical phenomena remain active (Iverson, 2005); turbulence is muted or absent and debris flows typically exhibit laminar flow (Pierson, 1995; Procter and others, 2009). Finally, debris avalanches undergo transport largely via solid mechanical phenomena with little to no contribution from the subordinate or entirely lacking fluid phase (Iverson, 2005). Note that once flow character is established within a cohesive lahar, flow transformations along this continuum are relatively uncommon (Vallance, 2005; also appendix C). 
complex and define a continuum of processes (Collinson, 1996), and thus distinguishing among alluvial depositional environments in the rock record may in many cases be rather difficult (Nilsen, 1982). Moreover, these distinctions may be further complicated where voluminous, unconsolidated juvenile volcaniclastic material is transported via processes (such as hyperconcentrated and debris flows) that more commonly dominate fan settings in non-volcanic environments but frequently travel many tens of kilometers beyond fans and onto broad floodplains in volcanic environments. Thus, despite the abundance of boulder-bearing debris-flow deposits and associated hyperconcentrated-flow facies in Qvc that may suggest alluvial fan deposition in non-volcanic settings, these observations are less uniquely compelling for such a conclusion within the context of Qvc. We are, however, skeptical that the largest boulders of lithofacies 1 (up to $3.7 \mathrm{~m}$ apparent long dimension; fig. 8C) would be transported more than several kilometers beyond the limits of confined, highly channelized flow (compare to Pierson and others, 1990) that characterize the more proximal depositional reaches of volcaniclastic-sediment-dominated alluvial systems. The subQve unconformity also indicates that the volcaniclastic strata of this study began aggrading in a paleovalley that had been incised into the underlying Paleogene and Neogene Cook Inlet forearc basin stratigraphy. These relations suggest that, at a minimum, the volcaniclastic sediments infilled pre-existing topographic relief during establishment of the Qvc depositional system and thus did not accumulate along a regionally extensive basin floor. Additionally, the volcaniclastic deposits of Qvc at the plateau locality must record only a limited part of a depositional system and resultant volcaniclastic succession, both of which were once presumably much greater in original areal extent. Much of the Qvc depositional system has undoubtedly been removed by latest Pleistocene and Holocene erosion (predominantly glacial?), and we are unaware of any correlative strata or associated paleogeographic elements - with the noted possible exception of ancestral Mount Spurr itself - beyond the volcaniclastic plateau of this study. Thus, the limited geographic distribution of Qvc presents additional challenges in determining the overall context of the former depositional site. Nevertheless, our observations and interpretations of Qvc_-placed in the context of potentially analogous modern depositional systems - suggest this unit aggraded on a relatively low-gradient alluvial fan or floodplain in an area exhibiting hundreds of meters of topographic relief, and likely within tens of kilometers of the uppermost reaches of a volcaniclastic detritus-rich source catchment(s).

\section{SUMMARY}

Previous studies in the Capps Glacier area of the Tyonek Quadrangle recognized a distinctly mappable unit comprising the conglomeratic to sandy to clay-rich strata of Qvc that crop out along the margins of the volcaniclastic plateau, but age constraints and detailed facies descriptions were lacking until now. An angular unconformity underlies the 275 -m-thick Qvc (maximum exposed stratal thickness), and the mapped trace of this unconformity suggests hundreds of meters of paleotopographic relief. Although the bulk of observed bedding dips are horizontal to subhorizontal, possibly reflecting primary dips, locally gently dipping panels of Qvc may be tectonically deformed. Some of the volcaniclastic deposits were susceptible to post-depositional liquefaction and/or fluidization as evidenced by clastic intrusions hosted in chaotically folded Qve strata; inferred soft sediment deformation processes may have been triggered by regional seismicity and/or depositional loading related to high instantaneous rates of sedimentation. New U-Pb detrital zircon results, in conjunction with glacial deposit age assessments and cross-cutting relations, bracket deposition of Qvc to middle to late Pleistocene but prior to MIS 4. Our observations and interpretations suggest that Qve strata dominantly record sedimentation from hyperconcentrated flows and debris flows (lahars) in a volcaniclastic-sediment-choked alluvial system, likely at a site comprising a low-gradient alluvial fan or floodplain. The clay-rich deposits described in this report may record sector-collapse-related debris avalanche(s) that transformed into clayey debris flows. Age constraints reported in this study partly overlap available ${ }^{40} \mathrm{~K}-{ }^{40} \mathrm{Ar}$ ages for ancestral Mount Spurr eruptive products; this ancestral stratovolcano, which comprises the caldera rim surrounding modern Mount Spurr volcano, may have been the source of some, or possibly all, of the juvenile volcanogenic material in Qvc. Although the Qvc depositional system was undoubtedly well developed during middle to late Pleistocene time, any stratigraphic vestige of this system beyond the modern volcaniclastic plateau has been subsequently dismantled by erosion or has yet to be recognized.

\section{ACKNOWLEDGMENTS}

Funding for work in the Tyonek-Capps Glacier area was provided by the State of Alaska, the National Cooperative Geologic Mapping Program's STATEMAP program under award numbers 09AC00177 and G10AC00321 (administered by the USGS), and program receipts from industry sponsors. Cook Inlet Region, Inc. (CIRI), granted permission to conduct fieldwork in the study area.

This study benefited from discussions with Jeff Benowitz, Andy Calvert, Michelle Coombs, Paul Layer, Kate Bull, Rick Stanley, Paul Decker, De Anne Stevens, Ken Helmold, and Dave Mauel. DGGS intern Kandace Krejci managed our field database in 2009. Helicopter pilot Tom Ratledge safely transported our crew during summer 2009 fieldwork in the area.

Chris Waythomas and Rick Stanley provided insightful reviews of the manuscript. Paula Davis edited this paper and Joni Robinson provided the formatting and layout.

\section{REFERENCES CITED}

Barnes, F.F., 1966, Geology and coal resources of the BelugaYentna region, Alaska: U.S. Geological Survey Bulletin 1202-C, p. C1-C54, 4 sheets, scale 1:63,360.

Beverage, J.P., and Culbertson, J.K, 1964, Hyperconcentrations of suspended sediment: Journal of the Hydraulics 
Division, Proceedings of the American Association of Civil Engineers, v. 90, p. 117-128.

Bradley, Dwight, Haeussler, Peter, O’Sullivan, Paul, Friedman, Rich, Till, Alison, Bradley, Dan, and Trop, Jeff, 2009, Detrital zircon geochronology of Cretaceous and Paleogene strata across the south-central Alaskan convergent margin: U.S. Geological Survey Professional Paper 1760-F, 36 p.

Briner, J.P., Kaufman, D.S., Finkel, R.C., and Caffee, M.W., 2005, Cosmogenic exposure dating of late Pleistocene moraine stabilization in Alaska: Geological Society of America Bulletin, v. 117, p. 1,108-1,120.

Calderwood, K.W., and Fackler, W.C., 1972, Proposed stratigraphic nomenclature for Kenai Group, Cook Inlet basin, Alaska: American Association of Petroleum Geologists Bulletin, v. 56, p. 739-754.

Capps, S.R., 1935, The southern Alaska Range: U.S. Geological Survey Bulletin 862, 101 p., 2 sheets, scale 1:250,000.

Carrasco-Nuñez, G., Vallance, J.W., and Rose, W.I., 1993, A voluminous avalanche-induced lahar from Citlaltépetl Volcano, Mexico-Implications for hazard assessment: Journal of Volcanology and Geothermal Research, v. 59, p. $35-46$.

Cassel, E.J., and Graham, S.A., 2011, Paleovalley morphology and fluvial system evolution of Eocene-Oligocene sediments ("auriferous gravels"), northern Sierra Nevada, California-Implications for climate, tectonics, and topography: Geological Society of America Bulletin, v. 123, p. 1,699-1,719.

Chang, Zhaoshan, Vervoort, J.D., McClelland, W.C., and Knaack, Charles, 2006, U-Pb dating of zircon by LAICP-MS: Geochemistry, Geophysics, and Geosystems, v. 7, no. 5, p. 1-14, Q05009, DOI: 10.1029/2005GC001100.

Collinson, J.D., 1996, Alluvial sediments, in Reading, H.G., ed., Sedimentary Environments-Processes, Facies, and Stratigraphy: Blackwell Science, ch. 3, p. 37-82.

Compton, R.R., 1985, Geology in the Field: New York, John Wiley \& Sons, 398 p.

Crandell, D.R., 1971, Post-glacial lahars from Mount Rainier volcano, Washington: U.S. Geological Survey Professional Paper 677, 75 p.

Cronin, S.J., Neall, V.E., Lecointre, J.A., and Palmer, A.S., 1999, Dynamic interactions between lahars and stream flow - A case study from Ruapehu volcano, New Zealand: Geological Society of America Bulletin, v. 111, p. 28-39.

Cronin, S.J., Lecointre, J.A., Palmer, A.S., and Neall, V.E., 2000, Transformation, internal stratification, and depositional processes in a channelised, multi-peaked lahar flow: New Zealand Journal of Geology and Geophysics, v. 43, p. 117-128.

DeCelles, P.G., Carrapa, B., and Gehrels, G.E., 2007, Detrital zircon $\mathrm{U}-\mathrm{Pb}$ ages provide provenance and chronostratigraphic information from Eocene synorogenic deposits in northwestern Argentina: Geology, v. 35, p. 323-326.

Dickinson, W.R., and Gehrels, G.E., 2009a, Use of U-Pb ages of detrital zircons to infer maximum depositional ages of strata-A test against a Colorado Plateau Mesozoic database: Earth and Planetary Science Letters, v. 288, p. $115-125$.

$-2009 b, \mathrm{U}-\mathrm{Pb}$ ages of detrital zircons in Jurassic eolian and associated sandstones of the Colorado PlateauEvidence for transcontinental dispersal and intraregional recycling of sediment: Geological Society of America Bulletin, v. 121, p. 408-433.

Dodson, M.H., 1988, A search for ancient detrital zircons in Zimbabwean sediments: Journal of the Geological Society of London, v. 145, p. 977-983.

Farrell, S.G., and Eaton, S., 1987, Slump strain in the Tertiary of Cyprus and the Spanish Pyrenees-Definition of palaeoslopes and models of soft-sediment deformation, in Jones, M.E., and Preston, R.F., eds., Deformation of Sediments and Sedimentary Rocks: Geological Society Special Publication 29, p. 181-196.

Fildani, A., Cope, T.D., Graham, S.A., and Wooden, J.L., 2003, Initiation of the Magallanes foreland basinTiming of the southernmost Patagonian Andes orogeny revised by detrital zircon provenance analysis: Geology, v. 31, p. 1,081-1,084.

Finzel, E.S., Trop, J.M., Ridgway, K.D., and Enkelmann, E., 2011, Upper plate proxies for flat-slab subduction processes in southern Alaska: Earth and Planetary Science Letters, v. 303, p. 348-360.

Fisher, R.V., 1961, Proposed classification of volcaniclastic sediments and rocks: Geological Society of America Bulletin, v. 72, p. 1,409-1,414.

1983, Flow transformations in sediment gravity flows: Geology, v. 11, p. 273-274.

Foster, H.L., and Karlstrom, T.N.V., 1967, Ground breakage and associated effects in the Cook Inlet area, Alaska, resulting from the March 27, 1964, earthquake: U.S. Geological Survey Professional Paper 543-F, p. F1-F28, 3 sheets, scale 1:1,000,000.

Gehrels, G.E., 2000, Introduction to detrital zircon studies of Paleozoic and Triassic strata in western Nevada and northern California, in Soreghan, M.J., and Gehrels, G.E., eds., Paleozoic and Triassic paleogeography and tectonics of western Nevada and northern California: Geological Society of America Special Paper 347, p. 1-18.

2012, Detrital zircon U-Pb geochronology_Current methods and new opportunities, in Busby, C., and Pérez, A.A., eds., Tectonics of Sedimentary Basins-Recent Advances: Wiley-Blackwell, ch. 2, p. 47-62.

Gillis, R.J., Herriott, T.M., Shellenbaum, D.P., Wartes, M.A., Decker, P.L., Mauel, D.J., and Gregersen, L.S., in preparation, Geologic map of the south-central Tyonek Quadrangle, Alaska: Alaska Division of Geological \& Geophysical Surveys Report of Investigation, scale $1: 63,360$.

Glicken, Harry, 1986, Rockslide-debris avalanche of May 18, 1980, Mount St. Helens Volcano, Washington: Santa Barbara, University of California at Santa Barbara, Ph.D. dissertation, $303 \mathrm{p}$. 
Sedimentary architecture of large volcanic-debris avalanches, in Fisher, R.V., and Smith, G.A., eds., Sedimentation in Volcanic Settings: Society for Sedimentary Geology (SEPM) Special Publication 45, p. 99-106.

Glicken, Harry, 1996, Rockslide-debris avalanche of May 18, 1980, Mount St. Helens Volcano, Washington: U.S. Geological Survey Open-file Report 96-677, 90 p.

Glicken, Harry, Meyer, W., and Sabol, M.A, 1989, Geology and ground-water hydrology of Spirit Lake blockage, Mount St. Helens, Washington, with implications for lake retention: U.S. Geological Survey Bulletin 1789, 33 p.

Haeussler, P.J., Bruhn, R.L., and Pratt, T.L., 2000, Potential seismic hazards and tectonics of the upper Cook Inlet basin, Alaska, based on analysis of Pliocene and younger deformation: Geological Society of America Bulletin, v. 112, p. 1,414-1,429.

Hansen, W.R., Eckel, E.B., Schaem, W.E., Lyle, R.E., Warren, G., and Chance, G., 1966, The Alaska earthquake March 27, 1964-Field investigations and reconstruction effort: U.S. Geological Survey Professional Paper 541, 111 p.

Herriott, T.M., 2006, Stratigraphy, structure, and ${ }^{40} \mathrm{Ar} /{ }^{39} \mathrm{Ar}$ geochronology of the southeastern Laguna del Laja area-Implications for the mid-late Cenozoic Evolution of the Andes near $37.5^{\circ} \mathrm{S}$, Chile: Santa Barbara, University of California at Santa Barbara, master's thesis, $97 \mathrm{p}$.

Hults, C.P., Wilson, F.H., Donelick, R.A., and O'Sullivan, P.B., 2013, Two flysch belts having distinctly different provenance suggest no stratigraphic link between the Wrangellia composite terrane and the paleo-Alaskan margin: Lithosphere, v. 5, no. 6, p. 575-594.

Iverson, R.M., 1997, The physics of debris flows: Reviews of Geophysics, v. 35, p. 245-296.

2005, Debris-flow mechanics, in Jakob, Matthias, and Hungr, Oldrich, eds., Debris-flow Hazards and Related Phenomena: Springer-Praxis Books, ch. 6, p. 105-134.

Lowe, D.R., 1975, Water escape structures in coarse-grained sediments: Sedimentology, v. 22, p. 157-204.

Lowe, D.R., and Guy, Martin, 2000, Slurry-flow deposits in the Britannia Formation (Lower Cretaceous), North Sea-A new perspective on the turbidity current and debris flow problem: Sedimentology, v. 47, no. 1, p. 31-70.

Lowe, D.R., Williams, S.N., Leigh, H., Connor, C.B., Gemmell, J.B., and Stoiber, R.E., 1986, Lahars initiated by the 13 November 1985 eruption of Nevado del Ruiz, Columbia: Nature, v. 324, p. 51-53.

Ludwig, K.R., 2008, Isoplot 3.70, A geochronologic toolkit for Microsoft Excel: Berkeley Geochronology Center Special Publication No. 4 (revised 26 August 2008), 70 p.

Magoon, L.B., Adkison, W.L., and Egbert, R.M., 1976, Map showing geology, wildcat wells, Tertiary plant fossil localities, K-Ar age dates, and petroleum operations, Cook Inlet area, Alaska: U.S. Geological Survey Miscellaneous Investigations 1019, 3 sheets, scale 1:250,000.

Major, J.J., 1997, Depositional processes in large-scale debris-flow experiments: The Journal of Geology, v. 105, p. 345-366.
1998, Pebble orientation on large, experimental debris-flow deposits: Sedimentary Geology, v. 117, p. 151-164.

Major, J.J., and Newhall, C.G., 1989, Snow and ice perturbation during historical volcanic eruptions and the formation of lahars and floods-A global review: Bulletin of Volcanology, v. 52, p. 1-27.

Major, J.J., Pierson, T.C., Dinehart, R.L., and Costa, J.E., 2000, Sediment yield following severe volcanic disturbance-A two-decade perspective from Mount St. Helens: Geology, v. 28, p. 819-822.

Major, J.J., Pierson, T.C., and Scott, K.M., 2005, Debris flows at Mount St. Helens, Washington, USA, in Jakob, Matthias, and Hungr, Oldrich, eds., Debris-flow Hazards and Related Phenomena: Springer-Praxis Books, ch. 27, p. 685-731.

Manville, V., Németh, K., and Kano, K., 2009, Source to sink-A review of three decades of progress in the understanding of volcaniclastic processes, deposits, and hazards: Sedimentary Geology, v. 220, p. 136-161.

Matmon, A., Briner, J.P., Carver, Gary, Bierman, P., and Finkel, R.C., 2010, Moraine chronosequence of the Donnelly Dome region, Alaska: Quaternary Research, v. 74, no. 1, p. 63-72.

Montenat, Christian, Barrier, Pascal, Ott d'Estevou, Philippe, and Hibsch, Christian, 2007, Seismites-An attempt at critical analysis and classification: Sedimentary Geology, v. 196, no. 1-4, p. 5-30.

Moretti, Massimo, and Sabato, L., 2007, Recognition of trigger mechanisms for soft-sediment deformation in the Pleistocene lacustrine deposits of the Sant'Arcangelo Basin (southern Italy) - Seismic shock vs. overloading: Sedimentary Geology, v. 196, no. 1-4, p. 31-45.

Naranjo, J.L., Sigurdsson, H., Carey, S.N., and Fritz, W., 1986, Eruption of Nevado del Ruiz volcano, Columbia, on 13 November 1985-Tephra fall and lahars: Science, v. 233, p. 961-963.

Neall, V.E., 1976, Lahars as major geological hazards: Bulletin of the International Association of Engineering Geologists, v. 14, p. 233-240.

Nelson, D.R., 2001, An assessment of the determination of depositional ages for Precambrian clastic sedimentary rocks by $\mathrm{U}-\mathrm{Pb}$ dating of detrital zircons: Sedimentary Geology, v. 141-142, p. 37-60.

Nilsen, T.H., 1982, Alluvial fan deposits, in Scholle, P.A., and Spearing, D., eds., Sandstone Depositional Environments: American Association of Petroleum Geologists Memoir 31, p. 49-86.

Nye, C.J., and Turner, D.L., 1990, Petrology, geochemistry, and age of the Spurr volcanic complex, eastern Aleutian arc: Bulletin of Volcanology, v. 52, p. 429-452.

Obermeier, S.F., 1996, Use of liquefaction-induced features for paleoseismic analysis - An overview of how seismic liquefaction features can be distinguished from other features and how their regional distribution and properties of source sediment can be used to infer the location 
and strength of Holocene paleo-earthquakes: Engineering Geology, v. 44, p. 1-76.

Obermeier, S.F., Pond, E.C., Olson, S.M., and Green, R.A., 2002, Paleoliquefaction studies in continental settings, in Ettensohn, F.R., Rast, N., and Brett, C.E., eds, Ancient Seismites: Geological Society of America Special Paper 359, p. 13-27.

Oomkens, Eppo, 1966, Environmental significance of sand dikes: Sedimentology, v. 7, no. 2, p. 145-148.

Owen, G., 1987, Deformation processes in unconsolidated sands, in Jones, M.E., Preston, R.F., eds., Deformation of Sediments and Sedimentary Rocks: Geological Society Special Publication no. 29, p. 11-24.

Palmer, B.A., Alloway, B.V., and Neall, V.E., 1991, Volcanicdebris-avalanche deposits in New Zealand-Lithofacies organization in unconfined, wet-avalanche flows, in Fisher, R.V. and Smith, G.A., eds., Sedimentation in Volcanic Settings: Society for Sedimentary Geology (SEPM) Special Publication 45, p. 89-98.

Pierson, T.C., 1985, Initiation and flow behavior of the 1980 Pine Creek and Muddy River lahars, Mount St. Helens, Washington: Geological Society of America Bulletin, v. 96, p. 1,056-1,069.

1995, Flow characteristics of large eruption-triggered debris flows at snow-clad volcanoes-Constraints for debris-flow models: Journal of Volcanology and Geothermal Research, v. 66, p. 283-294.

ed., 1999, Hydraulic consequences of hot-rock/ snowpack interaction at Mount St. Helens volcano, Washington, 1982-84: U.S. Geological Survey Professional Paper 1586, 103 p.

2005, Hyperconcentrated flow-Transitional process between water flow and debris flow, in Jakob, Matthias, and Hungr, Oldrich, eds., Debris-flow Hazards and Related Phenomena: Springer-Praxis Books, ch. 8, p. 159-202.

Pierson, T.C., and Scott, K.M., 1985, Downstream dilution of a lahar: Transition from debris flow to hyperconcentrated streamflow: Water Resources Research, v. 21, p. 1,511-1,524.

Pierson, T.C., and Costa, J.E., 1987, A rheologic classification of subaerial sediment-water flows: Geological Society of America, Reviews in Engineering Geology, v. 7, p. 1-12.

Pierson, T.C., Janda, R.J., Thouret, Jean-Claude, and Borrero, C.A., 1990, Perturbation and melting of snow and ice by the 13 November 1985 eruption of Nevado del Ruiz, Colombia, and consequent mobilization, flow, and deposition of lahars: Journal of Volcanology and Geothermal Research, v. 41, p. 17-66.

Pierson, T.C., Daag, A.S., Delos Reyes, P.J., Regalado, M.T.M., Solidum, R.U., and Tubianosa, B.S., 1996, Flow and deposition of post-eruption hot lahars on the east side of Mount Pinatubo, July-October 1991, in Newhall, C.G., and Punongbayan, R.S., eds., Fire and Mud-Eruptions and Lahars of Mount Pinatubo, Philippines: University of Washington Press, p. 921-950.

Pierson, T.C., Scott, W.E., Vallance, J.W., and Pringle, P.T., 2009, Eruption-related lahars and sedimentation response downstream of Mount Hood-Field guide to volcaniclastic deposits along the Sandy River, Oregon: Geological Society of America Field Guides, v. 15, p. 221-236.

Plafker, George, 1969, Tectonics of the March 27, 1964, Alaska earthquake: U.S. Geological Survey Professional Paper 543-1, 74 p.

Procter, J.N., Cronin, S.J., and Zernack, A.V., 2009, Landscape and sedimentary responses to catastrophic debris avalanches, western Taranaki, New Zealand: Sedimentary Geology, v. 220, no. 3-4, p. 271-287.

Reger, R.D., Stevens, D.S.P., and Koehler, R.D., in preparation, Surficial geology of the south-central Tyonek Quadrangle, Alaska: Alaska Division of Geological \& Geophysical Surveys Report of Investigation, number not yet assigned.

Rodolfo, K.S., 2000, The hazard from lahars and jökulhlaups, in Sigurdsson, H., Houghton, B., McNutt, S.R., Rymer, H., and Stix, J., eds, Encyclopedia of Volcanoes: Academic Press, p. 973-995.

Rodolfo, K.S., Arguden, A.T., Solidum, R.U., and Umbal, J.V., 1989, Anatomy and behavior of a post-eruptive rain lahar triggered by a typhoon on Mayon Volcano, Philippines: International Association of Engineering Geologists Bulletin, v. 40, p. 79-90.

Rodolfo, K.S., and Arguden, A.T., 1991, Rain-lahar generation and sediment-delivery systems at Mayon Volcano, Philippines, in Fisher, R.V., and Smith, G.A., eds., Sedimentation in Volcanic Settings: Society for Sedimentary Geology (SEPM) Special Publication 45, p. 71-87.

Rodolfo, K.S., Umbal, J.V., Alonso, R.A., Remotigue, C.T., Paladio-Melosantos, M.L., Salvador, J.H.G., Evangelista, D., and Miller, Y., 1996, Two years of lahars on the western flank of Mount Pinatubo-Initiation, flow processes, deposits, and attendant geomorphic and hydraulic changes, in Newhall, C.G., and Punongbayan, R.S., eds., Fire and Mud-Eruptions and Lahars of Mount Pinatubo, Philippines: University of Washington Press, p. 989-1,013.

Schaefer, J.R., ed., 2012, The 2009 eruption of Redoubt Volcano, Alaska: Alaska Division of Geological \& Geophysical Surveys Report of Investigations 2011-5, 45 p.

Scott, K.M., 1988, Origins, behavior, and sedimentology of lahars and lahar-runout flows in the Toutle-Cowlitz River system: U.S. Geological Survey Professional Paper 1447-A, 75 p.

1989, Magnitude and frequency of lahars and laharrunout flows in the Toutle-Cowlitz River system: U.S. Geological Survey Professional Paper 1447-B, 33 p.

Scott, K.M., Vallance, J.W., and Pringle, P.T., 1995, Sedimentology, behavior, and hazards of debris flows at Mount Rainier, Washington: U.S. Geological Survey Professional Paper 1547, 56 p.

Scott, K.M., Janda, R.J., de la Cruz, E.G., Gabinete, Elmer, Eto, Ismael, Isada, Manuel, Sexon, Manuel, and Hadley, K.C., 1996, Channel and sedimentation responses to large volumes of 1991 volcanic deposits on the east flank of Mount Pinatubo, in Newhall, C.G., and Punongbayan, 
R.S., eds., Fire and Mud-Eruptions and Lahars of Mount Pinatubo, Philippines: University of Washington Press, p. 971-988.

Seed, H.B., and Lee, K.L., 1966, Liquefaction of saturated sands during cyclic loading: Journal of the Soil Mechanics and Foundations Division, Proceedings of the American Association of Civil Engineers, v. 92, p. 105-134.

Smith, G.A., 1986, Coarse-grained nonmarine volcaniclastic sediment-Terminology and depositional processes: Geological Society of America Bulletin, v. 97, p. 1-10.

1987, The influence of explosive volcanism on fluvial sedimentations - The Deschutes Formation (Neogene) in central Oregon: The Journal of Sedimentary Petrology, v. 57 , p. $613-629$.

1991, Facies sequences and geometries in continental volcaniclastic sediments, in Fisher, R.V., and Smith, G.A., eds., Sedimentation in Volcanic Settings: Society for Sedimentary Geology (SEPM) Special Publication 45, p. 109-121.

Smith, G.A., and Fritz, W.J., 1989, Volcanic influences on terrestrial sedimentation: Geology, v. 17, p. 375-376.

Smith, G.A., and Lowe, D.R., 1991, Lahars-Volcano-hydrologic events and deposition in the debris flow-hyperconcentrated flow continuum, in Fisher, R.V., and Smith, G.A., eds., Sedimentation in Volcanic Settings: Society for Sedimentary Geology (SEPM) Special Publication 45 , p. $59-70$.

Strong, Nikki, and Paola, Chris, 2008, Valleys that never were-Time surfaces versus stratigraphic surfaces: Journal of Sedimentary Research, v. 78, p. 579-593.

Surpless, K.D., Graham, S.A., Covault, J.A., and Wooden, J., 2006, Does the Great Valley Group contain Jurassic strata? Re-evaluation of the age and early evolution of a classic forearc basin: Geology, v. 34, p. 21-24.

Thouret, Jean-Claude, 1990, Effects of the November 13, 1985 eruption on the snow pack and ice cap of Nevado del Ruiz, Columbia: Journal of Volcanology and Geothermal Research, v. 41, no. 1-4, p. 177-201.

Thouret, Jean-Claude, Cantagrel, J.M., Salinas, Rosalba, and Murcia, A., 1990, Quaternary eruptive history of Nevado del Ruiz (Columbia): Journal of Volcanology and Geothermal Research, v. 41, no. 1-4, p. 225-251.

Vallance, J.W., 2000, Lahars, in Sigurdsson, H., Houghton, B., McNutt, S.R., Rymer, H., and Stix, J., eds, Encyclopedia of Volcanoes: Academic Press, p. 601-616.

2005, Volcanic debris flows, in Jakob, Matthias, and Hungr, Oldrich, eds., Debris-flow Hazards and Related Phenomena: Springer-Praxis Books, ch. 10, p. 247-274.

Vallance, J.W., and Scott, K.M., 1997, The Osceola Mudflow from Mount Rainier-Sedimentology and hazard implications of a huge clay-rich debris flow: Geological Society of America Bulletin, v. 109, no. 2, p. 143-163.
Vermeesch, Pieter, 2004, How many grains are needed for a provenance study?: Earth and Planetary Science Letters, v. 224, no. 3-4, p. 441-451.

Waitt, R.B., Jr., 1989, Swift snowmelt and floods (lahars) caused by great pyroclastic surge at Mount St. Helens volcano, Washington, 18 May 1980: Bulletin of Volcanology, v. 52, p. 138-157.

Waitt, R.B., Jr., Pierson, T.C., Macleod, N.S., Janda, R.J., Voight, Barry, and Holocomb, R.T., 1983, Eruptiontriggered avalanche, flood, and lahar at Mount St. Helens-Effects of winter snowpack: Science, v. 221, no. 4618, p. 1,394-1,397.

Walsh, T.J., Combellick, R.A., and Black, G.L., 1995, Liquefaction features from a subduction zone earthquakePreserved examples from the 1964 Alaska earthquake: Washington Division of Geology and Earth Resources Report of Investigations 32, $80 \mathrm{p}$.

Waythomas, C.F., 2007, Mid-Holocene sector collapse at Mount Spurr volcano, south-central Alaska: U.S. Geological Survey Professional Paper 1739-C, 15 p.

Waythomas, C.F., Walder, J.S., McGimsey, R.G., and Neal, C.A., 1996, A catastrophic flood caused by draining of a caldera lake at Aniakchak volcano, Alaska, and implications for volcanic hazards assessment: Geological Society of America Bulletin, v. 108, p. 861-871.

Waythomas, C.F., Pierson, T.C., Major, J.J., and Scott, W.E., 2012, Preliminary observations of voluminous ice-rich and water-rich lahars generated during the 2009 eruption of Redoubt Volcano, Alaska: U.S. Geological Survey Open-File Report 2012-1078, 42 p.

Wilson, F.H., Hults, C.P., Schmoll, H.R., Haeussler, P.J., Schmidt, J.M., Yehle, L.A., and Labay, K.A., 2009, Preliminary geologic map of the Cook Inlet region, Alaska: U.S. Geological Survey Open-File Report 2009-1108, 52 p., 2 sheets, scale 1:250,000.

2012, Geologic map of the Cook Inlet region, Alaska, including parts of the Talkeetna, Talkeetna Mountains, Tyonek, Anchorage, Lake Clark, Kenai, Seward, Iliamna, Seldovia, Mount Katmai, and Afognak quadrangles: U.S. Geological Survey Scientific Investigations Map 3153, 76 p., 2 sheets, scale 1:250,000.

Yehle, L.A., Schmoll, H.R., and Chleborad, A.F., 1983, Preliminary surficial geologic map of the southwestern part of the Tyonek B-5 Quadrangle, south-central Alaska: U.S. Geological Survey Miscellaneous Field Studies 1661-B, 1 sheet, scale 1:31,680.

Youd, T.L., 1973, Liquefaction, flow, and associated ground failure: U.S. Geological Survey Circular 688, 12 p.

Zernack, A.V., Procter, J.N., and Cronin, S.J., 2009, Sedimentary signatures of cyclic growth and destruction of stratovolcanoes - A case study from Mt. Taranaki, New Zealand: Sedimentary Geology, v. 220, p. 288-305. 


\section{Appendix A}

\section{A Brief Introduction to Fluidization and Liquefaction}

Fluidization occurs as pore-water velocity through sediment exerts sufficient drag on framework grains such that particle weight is overcome and the sediment loses its internal strength (Lowe, 1975; also Owen, 1987). When the minimum fluidization velocity is exceeded, sediment transport, typically turbulent, takes place. Liquefaction, which only acts on saturated sediments (Obermeier, 1996), occurs when pore-water pressure is equal to overburden pressure and a formerly framework-grainsupported sediment body can act as a viscous fluid with little to no shear strength (Seed and Lee, 1966; Youd, 1973; Lowe, 1975; Owen, 1987; Obermeier, 1996). Liquefaction-susceptible sediments (in the sense of Obermeier and others, 2002) are typically cohesionless, fine to medium (Lowe, 1975) or coarse (Obermeier and others, 2002) sand, but the degree to which finer-grained sediment (such as silt) affects the susceptibility of a sediment body to liquefy is not yet thoroughly understood (Obermeier and others, 2002). Walsh and others (1995) also demonstrated that liquefied medium- to coarse-grained sand may contain significant fractions of granule- and pebble-sized material. Liquefied sediments that are deformed generally undergo laminar flow with relatively negligible porewater velocities; turbulent suspension (or elutriation of finer-grained material) of all but the finest grain-size fraction does not occur and only the largest and heaviest particles differentially settle in a liquefied sediment (Lowe, 1975; also Owen, 1987). 


\section{Appendix B}

\section{U-Pb Detrital Zircon Geochronology Results}

Data table B1, presented below, is re-tabulated from Microsoft Excel ${ }^{\circledR}$ spreadsheets of U-Pb LA-ICP-MS analytical results provided by A to Z, Inc. We do not include grains 109833_100, 109833_104, and 109833_75 (sample 09TMH323A; see strike-through) in plots presented in the paper (fig. 7) due to their exceedingly large 2-sigma errors. 
Table B1. Laboratory analytical results for detrital zircon samples 09TMH323A and 09TMH342A.

\begin{tabular}{|c|c|c|c|c|c|c|c|c|c|c|c|c|c|c|c|c|c|c|c|c|c|c|c|c|c|}
\hline \multicolumn{26}{|c|}{\begin{tabular}{|l|} 
Sample name: 09TMH323A \\
A22 sample ID: 1098-33 \\
Mineral: zircon \\
\end{tabular}} \\
\hline \multirow[b]{2}{*}{$\begin{array}{l}\text { Analysis } \\
\text { Name }\end{array}$} & \multicolumn{3}{|c|}{ Uranium and Thorium } & \multicolumn{7}{|c|}{ Concordant Scans: Isotopic Ratios } & \multicolumn{9}{|c|}{ Concordant Scans: Ages } & \multicolumn{6}{|c|}{ Preferred Age } \\
\hline & 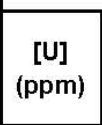 & \begin{tabular}{|l|l}
{$[\mathrm{Tp}]$} \\
$(\mathrm{ppm})$
\end{tabular} & $\mathrm{u} / \mathrm{Th}$ & 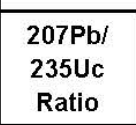 & 2 sigma & $\begin{array}{l}206 \mathrm{~Pb} / \\
\text { 238U } \\
\text { Ratio }\end{array}$ & 2 sigma & $\begin{array}{l}207 \mathrm{pb} / \\
\text { 2060 } \\
\text { 20atio } \\
\text { Ratio }\end{array}$ & 2sigma & $\begin{array}{l}\text { Error } \\
\text { correl- } \\
\text { ation }\end{array}$ & 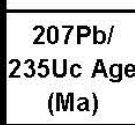 & & $\begin{array}{c}2+ \\
\text { sigma }\end{array}$ & 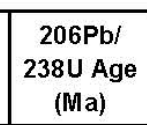 & $2-5 i$ & $\stackrel{2}{2}$ & 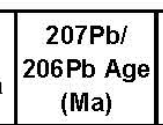 & 2-sigma | & & $\begin{array}{l}\text { referer- } \\
\text { red } \\
\text { (age }\end{array}$ & 2 -sigm & $2+$ sigma & Age Type & $\begin{array}{c}\text { concor- } \\
\text { dant } \\
\text { scans }\end{array}$ & \begin{tabular}{|l|l} 
Total \\
scans
\end{tabular} \\
\hline & & & & $\frac{0.00070}{0.0102}$ & & & & & & & 0.71 & $\frac{1.43}{-1.85}$ & & $\begin{array}{l}0.31 \\
031 \\
\end{array}$ & $\frac{0.17}{0.14}$ & & & & & & 0.17 & & 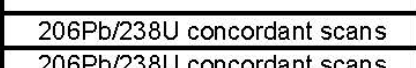 & & \\
\hline 1.9083333-91 & $\frac{242}{211}$ & $\frac{356}{144}$ & $\frac{1.13}{1.46}$ & $\begin{array}{l}0.0122 \\
0.00117 \\
\end{array}$ & $\begin{array}{l}0.00183 \\
0.00271 \\
y\end{array}$ & $\begin{array}{l}0.00005 \\
0.0005\end{array}$ & 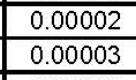 & 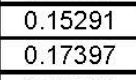 & $\begin{array}{ll}0.2180 \\
0.4192 \\
\end{array}$ & \begin{tabular}{|l|l|l|l}
0.00 \\
0.00
\end{tabular} & $\begin{array}{l}\frac{1.04}{1.19} \\
\end{array}$ & $\frac{1.85}{2.38}$ & $\frac{1.85}{2.74}$ & \begin{tabular}{|l|l|}
0.32 \\
\end{tabular} & $\frac{0.14}{0.222}$ & \begin{tabular}{|l|l|l|}
0.142 \\
0.22
\end{tabular} & \begin{tabular}{ll|}
2358.70 \\
250.20 \\
\end{tabular} & 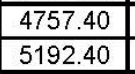 & \begin{tabular}{|l|l|l|l|l|l|l|}
2501.83 \\
\end{tabular} & $\begin{array}{ll}0.31 \\
0.32 \\
\end{array}$ & $\frac{0.14}{0.22}$ & 0.14 & 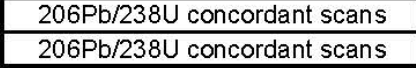 & & $\frac{177}{177}$ \\
\hline $\begin{array}{l}9833234 \\
9833-74\end{array}$ & $\frac{239}{188}$ & $\frac{136}{132}$ & $\frac{1.75}{1.43}$ & $\begin{array}{l}0.0106 \\
0.00163\end{array}$ & $\begin{array}{l}0.00225 \\
0.00336 \\
\end{array}$ & $\frac{0.0005}{0.00005}$ & $\begin{array}{l}0.00003 \\
0.00004\end{array}$ & $\begin{array}{l}0.15272 \\
0.22938\end{array}$ & \begin{tabular}{|l|l|}
0.35011 \\
0.50558 \\
\end{tabular} & \begin{tabular}{|l|l|l}
0.00 \\
0.00 \\
\end{tabular} & $\frac{1.08}{1.1 .5}$ & $\frac{2.15}{3.30}$ & $\frac{2.28}{3.41}$ & \begin{tabular}{|l|l|l}
0.33 \\
0.33
\end{tabular} & $\begin{array}{ll}0.19 \\
0.25\end{array}$ & \begin{tabular}{|l|l|l|l|}
0.19 \\
0.25
\end{tabular} & \begin{tabular}{|l|l|}
2376.60 \\
3077.76 \\
\end{tabular} & $\begin{array}{ll}4753.19 \\
6609552\end{array}$ & 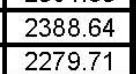 & $\frac{0.33}{0.33}$ & $\frac{0.19}{0.25}$ & $\frac{0.19}{0.25}$ & 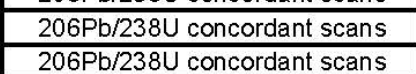 & & $\frac{174}{176}$ \\
\hline 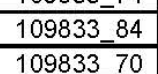 & $\frac{168}{1133}$ & $\frac{93}{93}$ & $\frac{1.80}{2.87}$ & $\frac{0.00189}{0.0303}$ & $\frac{0.00402}{0.00063}$ & $\begin{array}{l}\frac{0.0006}{0.0006} \\
0.006-150\end{array}$ & $\frac{0.00004}{0.00006}$ & $\frac{0.24250}{0.3675}$ & $\frac{0.54550}{0.6538}$ & \begin{tabular}{|l|l|l|l|}
0.00 \\
0.00
\end{tabular} & $\frac{1.91}{3.8}$ & $\frac{3.83}{470}$ & $\frac{4.07}{4.699}$ & \begin{tabular}{|l|l|l|}
0.36 \\
039
\end{tabular} & $\frac{0.26}{0.36}$ & $\begin{array}{l}0.26 \\
036\end{array}$ & $\frac{3136.46}{370.10}$ & 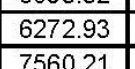 & 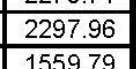 & $\frac{0.36}{0.399}$ & 0.26 & 0.26 & $\frac{8 U \text { concordant scans }}{814}$ & & $\frac{177}{175}$ \\
\hline & $\frac{123}{175}$ & $\frac{43}{199}$ & $\frac{2.87}{0.88}$ & $\frac{0.00303}{0.00178}-100$ & & $\frac{0.0006}{0.0007}$ & & & & 0.00 & $\frac{3.08}{1.81}$ & $\begin{array}{l}4.70 \\
3.56 \\
\end{array}$ & $\frac{4.69}{3.55}$ & $\begin{array}{l}0.39 \\
0.43 \\
\end{array}$ & $\frac{0.36}{0.28}$ & 0.36 & & & & & $\frac{0.36}{0.28}$ & & oncororants & & $\frac{175}{177}$ \\
\hline & 132 & 79 & 1.67 & $\frac{0.00161}{0.00161}$ & & $\begin{array}{l}0.000 \\
0.000\end{array}$ & & 0.1396: & $\frac{0.3925}{0.3925}$ & 0.00 & 1.63 & $\frac{3.26}{3.26}$ & 4.45 & \begin{tabular}{|l|l|} 
& 0.54 \\
\end{tabular} & 0.34 & 0.34 & & (4445.1. & & 0.54 & 0.34 & $\frac{0.34}{0.34}$ & cordanturt & & $\frac{1 / 1}{177}$ \\
\hline & & & & & & & & & & & $\frac{2.38}{484}$ & 4.76 & 5.04 & 0.6 & & & & & & & $\frac{0.41}{0.79}$ & & is & & $\frac{172}{177}$ \\
\hline & & & $\frac{1.84}{1.84}-3$ & & & & & & & & $\frac{4.8}{5.5}$ & 8. & $\frac{1.64}{8.84}$ & & & & & 159 & & & $\frac{0.98}{0.48}$ & & & & $\frac{177}{177}$ \\
\hline & $\frac{110}{1101}$ & $\frac{45}{161}$ & $\frac{2.45}{1.12}$ & $\frac{0.0208}{0.0208}$ & $\frac{0.0}{0.0}$ & $\frac{0.000}{0.000}$ & 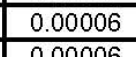 & (11000 & & 0.00 & $\frac{2.11}{2.1}$ & $\frac{4.22}{5.51}$ & $\frac{5.01}{5}$ & $\frac{0.7}{0.7}$ & $\frac{0.42}{0.25}$ & $0.42,0$ & STS & & (1) & $\frac{0.76}{0.77}$ & 0.42 & & foncordantats & & $\frac{174}{1774}$ \\
\hline & & 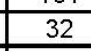 & $\frac{1.12}{2.56}$ & & & & & . & . & 0.00 & $\frac{0.35}{4.21}$ & 8.26 & $\frac{3.40}{8.22}$ & & 0.53 & & & & & & 0.55 & & 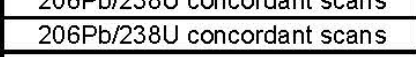 & & $\frac{173}{177}$ \\
\hline & 56 & & 1.87. & & & & & & 0.5815 & 0.000 & 6.83 & & 11.54 & & & & 35 & 7066 & & & & & U concordant scans & & 176 \\
\hline & $\frac{101}{62}$ & 27 & $\frac{1.55}{2.27}$ & $\begin{array}{l}0.00439 \\
0.00824\end{array}$ & 0.000868 & 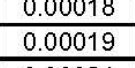 & 0.000 & 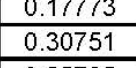 & 0.0 .46432 & $\frac{0.00}{0.00}$ & $\frac{4.44}{8.34}$ & $\frac{7.78}{11.86}$ & 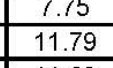 & \begin{tabular}{|l}
1.15 \\
1.25 \\
\end{tabular} & $\frac{0.48}{0.63}$ & 0.47 & \begin{tabular}{|l|l|l|l|l|l|}
2500.45 \\
\end{tabular} & 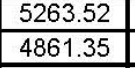 & & $\frac{1.15}{1.25}$ & 0.48 & $\frac{0.47}{0.63}$ & $\begin{array}{l}\text { Joconoordant scans } \\
\text { Uconcordant scans }\end{array}$ & & $\frac{174}{177}$ \\
\hline 333-104 & $\frac{69}{123}$ & $\frac{29}{89}$ & $\frac{2.38}{138}$ & $\frac{0.00748}{0.00841}$ & $\frac{0.01157}{0.01181}$ & $\frac{0.00021}{0.00222}$ & $\frac{0.000}{0.000}$ & $\frac{0.25735}{0.27325}$ & 0.41686 & 0.00 & $\frac{7.56}{851}$ & $\frac{11.70}{11.92}$ & $\frac{11.63}{1186}$ & \begin{tabular}{|l|l|}
1.36 \\
144
\end{tabular} & 0.65 & $\begin{array}{ll}0.65 \\
0.68\end{array}$ & $\frac{3230.57}{332777}$ & $\begin{array}{ll}6173.13 \\
443241\end{array}$ & 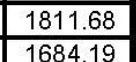 & $\frac{1.36}{1.44}$ & $\begin{array}{l}0.65 \\
0.68 \\
\end{array}$ & $\begin{array}{l}0.65 \\
0.68 \\
\end{array}$ & $\begin{array}{l}U \text { U concordant scans } \\
\text { Uconcordant tcans }\end{array}$ & & $\frac{177}{1177}$ \\
\hline & & & & & & & & & & $\frac{0.00}{0.00}$ & $\frac{.851}{12.14}$ & $\frac{11.92}{1572}$ & $\frac{11.60}{1560}$ & \begin{tabular}{|l|l|l|l|}
1.33 \\
\end{tabular} & 0.68 & $\begin{array}{ll}0.68 \\
18\end{array}$ & 368554 & 4/32.41] & & $\frac{1.44}{1.63}$ & $\frac{0.68}{118}$ & 0.68 & ns & & $\frac{177}{173}$ \\
\hline $33-37$ & 32 & 17 & $\frac{1.88}{1.88}$ & $\frac{0.01561}{0.0151}$ & & $\frac{0.0028}{0.0028}$ & & $\frac{0.40822}{0.03}$ & $\begin{array}{ll}0.70469 \\
\end{array}$ & 0.00 & $\frac{15.72}{15}$ & $\frac{23.81}{231}$ & 23.53 & 1.79 & $\frac{1.47}{1.47}$ & 1.47 & 3939.64 & $\frac{19884.40}{6694}$ & 12407 & $\frac{1.79}{1.79}$ & $\frac{1.47}{1.47}$ & 1.47 & icordants & 94 & $\frac{172}{172}$ \\
\hline 33_9 3106 & $\frac{28}{40}$ & $\frac{11}{19}$ & $\frac{2.65}{214}$ & $\frac{0.00812}{0.01762}-100$ & $\frac{0.0}{0.0}$ & $\frac{0.00035}{0.0071}$ & 0.00019 & $\frac{0.16662}{0.18052}$ & 0.43733 & 0.00 & $\frac{8.21}{1774}$ & $\frac{16.43}{34.47}$ & 20.89 & $\frac{2.28}{456}$ & $\frac{1.25}{1.71}$ & \begin{tabular}{c|c|c|}
1.25 \\
171
\end{tabular} & $\frac{2050.95}{26566}$ & 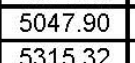 & 21777 & $\frac{2.28}{4.56}$ & $\begin{array}{c}1.25 \\
171 \\
\end{array}$ & $\frac{1.24}{1.7}$ & $\begin{array}{l}U \text { concordant } 5 \\
\text { concordants }\end{array}$ & & $\begin{array}{lll}177 \\
197\end{array}$ \\
\hline & & & $\frac{2.14}{4.20}$ & & & & & & & & $\frac{1.1 .4}{40.82}$ & 4.3 & $\frac{\frac{3.353}{4.33}}{43}$ & & $\frac{1.11}{1.18}$ & 1.71 & & & & & $\frac{1.18}{1.18}$ & 1.1 & $\begin{array}{l}\text { cordant scans } \\
\text { cordant scans }\end{array}$ & & $\frac{117}{177}$ \\
\hline & $\frac{64}{64}$ & & 101.26 & & & & & & & & 58.1 .1 & $\frac{3.5}{3.5}-2$ & $\frac{3.50}{3.50}$ & & & $\frac{1.3}{1.3}$ & & $\frac{152}{152}+2$ & 146.1 & & & & cordant st & & $\frac{117}{177}$ \\
\hline & $\frac{49}{217}$ & & 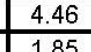 & & & & & & & & $\frac{5.32}{5.902}$ & $\frac{4}{2}$ & $\begin{array}{l}4.57 \\
.56\end{array}$ & $\frac{57}{57}$ & $\frac{1.4}{1.4}$ & & & 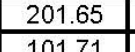 & & & $\frac{1.45}{1.45}$ & & corda & & 177 \\
\hline & $\frac{2136}{136}$ & 21 & $\frac{1.0}{6.5}-20$ & & & & & & & & & & & & & & & & & & & & :ordan & & \\
\hline & $\frac{243}{243}$ & $\underline{6}$. & 3.8. & & & 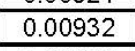 & & & 0.005 & & 62.5. & & 6.9 & 59 & 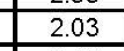 & & me & now & & 5098 & 203 & & 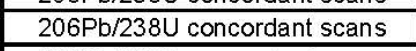 & & \\
\hline & 196 & & 3.5.5 & & & & & & & & 67.1 & & & & & & & 311. & & & 1.1 & & ordant & & 1 \\
\hline & $\frac{4896}{324}$ & $\frac{50}{19},{ }^{2}$ & $\begin{array}{l}\frac{207}{273} \\
2.73\end{array}$ & 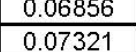 & $\frac{0.04}{0.07}$ & 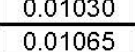 & $\frac{0.0}{0.0}$ & $\widehat{0498}$ & 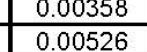 & $\frac{0.22}{0.06}$ & $\frac{6-3.33}{77.74}$ & $\begin{array}{l}\frac{4.7}{7 .} \\
7 .\end{array}$ & $\frac{4.72}{7.12}$ & $\frac{6}{6}$ & $\frac{2.6}{2.2}$ & & 18 & $\frac{155}{255}$ & & & 告.69 & & 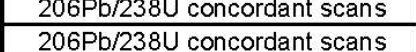 & & $\frac{177}{1177}$ \\
\hline & $\frac{29}{29}$ & & 5.04 & $\frac{0.075}{0.03}$ & 0.0074 & $\frac{0.010}{0.010}$ & & & 0.0051 & 0.04 & 73.555 & & 7.04 & $\frac{69}{69}$ & $\frac{1.9}{1.9}$ & 1.9. & & 244.3.3. & & & 1.94 & & Oncordant scans & & \\
\hline & & & 4.38 & & & $0.011:$ & & & 0.0115 & 0.0 & 75.52 & 17.6 & 16.88 & & 3.3 & 3.3. & & $262.3 \mathrm{~s}>\mathrm{l}$ & & & 3.35 & & & & $\frac{112}{174}$ \\
\hline 8338 & $\frac{100}{95}-1>$ & $\frac{35}{32}$ & $\frac{1.81}{293}-3$ & $\begin{array}{l}0.084141 \\
0.0330\end{array}$ & 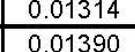 & $\begin{array}{l}\frac{0.0160}{0.1162} \\
01182\end{array}$ & 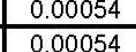 & $\frac{0511}{0.511}$ & 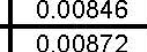 & 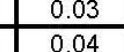 & $\frac{1947}{8.25}$ & $\frac{1.237}{1307}$ & 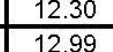 & $\frac{74.32}{7575}$ & $\frac{3.45}{3.4}$ & 年.43 & 告33.28 & 告 10.50 & & $\frac{14.32}{7575}$ & $\frac{3.45}{3.41}$ & $\frac{3.4}{3.3}$ & necordant & & $\frac{176}{1177}$ \\
\hline & 58 & & $\frac{2.37}{2.37}$ & & & 0 & & & 0.01382 & 0.02 & & & 20.80 & 76.78 & & & & & & & & & 84 concordant scans & & \\
\hline 833-69 & 102 & 43 & 2.38 & 0.10322 & 0.02784 & 0.01340 & 0.00057 & 0.05586 & 0.01520 & 0.01 & 99.74 & 25.78 & 25.46 & 85.81 & 3.61 & 3.60 & 446.99 & 669.59 & & 85.81 & 3.61 & 3.6 & $\frac{180 \text { concordant scans }}{38}$ & & $177^{173}$ \\
\hline & 292 & $\frac{52}{52}>0$ & $\frac{5.61}{5012}$ & 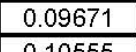 & 年 & 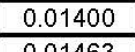 & 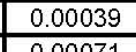 & 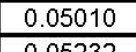 & 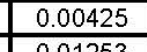 & 0.06 & $\frac{93.74}{93.79}$ & 1.40 & $\begin{array}{ll}7.38 \\
7.34\end{array}$ & & 2.45 & 2.40 & & 500 & & & $\frac{2.45}{20}$ & & & & \\
\hline & $\frac{49}{56}$ & $\frac{21}{24}, 45$ & 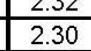 & & 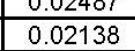 & 势 & & & & 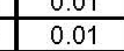 & $\frac{10.188}{98.16}$ & $\frac{2}{10.8 .}$ & 22.01 & $\frac{93.6}{94.3}$ & 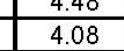 & & & & & $\frac{94}{94}$ & & & 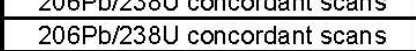 & & $\frac{1}{1}$ \\
\hline & 65 & & 1.4 .4 & & & & & & & & 97.8 & & 5.66 & 94.5 & 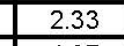 & & & 1477. & & & & & & & \\
\hline & 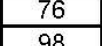 & $\frac{38}{44}>0$ & $\frac{2.0 .}{22^{2}}$ & 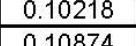 & & 14595 & & & & & $\frac{98.79}{-10.78}$ & $\frac{113 .}{11.5}$ & $\frac{15.5}{1.5}$ & & 告. & 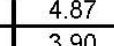 & & & & & $\begin{array}{l}4.87 \\
3.30\end{array}$ & & & & \\
\hline & $\begin{array}{ll}209 \\
299\end{array}$ & $\frac{47}{97}$ & 势 305 & & & & & & & & & & $\frac{10.00}{7.81}$ & & & & & $\frac{536}{156}$ & & & & & & & \\
\hline & $\frac{87}{83}$ & $\begin{array}{l}31 \\
377 \\
27\end{array}$ & $\frac{2.81}{202}$ & $\begin{array}{l}0.16447 \\
018972\end{array}$ & 0.01830 & $\frac{0.02367}{0.0256}$ & 0.00076 & $\frac{0.05040}{0.0515}$ & 0.00574 & 0.05 & $\begin{array}{ll}154.61 \\
140.11\end{array}$ & $\frac{16.02}{17.16}$ & $\frac{15.90}{17.22}$ & \begin{tabular}{|l|l|}
15.080 \\
150.8
\end{tabular} & $\frac{4.99}{7797}$ & $\begin{array}{lll}4.79 \\
777\end{array}$ & 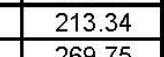 & $\frac{275.04}{257072}>0$ & 250.27 & $\begin{array}{l}150.80 \\
16200\end{array}$ & $\frac{4.79}{4.77}$ & $\begin{array}{ll}4.79 \\
727\end{array}$ & $206 \mathrm{~Pb} / 238 \mathrm{U}$ concorddant scans & 71 & $\frac{173}{174}$ \\
\hline & $\frac{o 11}{111}$ & & & & & & & & & & $\frac{105.14}{170.44}$ & & & \begin{tabular}{|l|l|}
162.20 \\
167.26 \\
\end{tabular} & & & & & & $\frac{162.00}{167.26}$ & & & 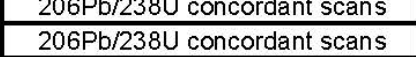 & $\begin{array}{ll}68 \\
75\end{array}$ & $\frac{114}{174}$ \\
\hline & $\frac{119}{272}$ & $\frac{35}{103}$ & $\frac{3.46}{3.5}$ & & $\frac{0.11}{0.01}$ & $\frac{0.026}{0.032}$ & 0.00074 & $\frac{0.050}{0.050}$ & $\frac{0.00488}{0.0265}$ & 0.06 & 170.52 & $\frac{15.12}{0.15}$ & $\frac{15.01}{0.11}$ & \begin{tabular}{|l|l|}
168.69 \\
10.00
\end{tabular} & $\frac{4.6}{4.4}$ & 4.6 & 195.94 & & 210.91 & 168.69 & 4.67 & $\frac{4.67}{4.43}$ & concordar & $\frac{65}{76}$ & $\frac{177}{1472}$ \\
\hline & $\frac{272}{241}$ & $\frac{105}{114}$ & $\frac{2.60}{2.12}$ & 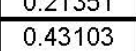 & 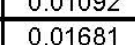 & 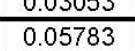 & $\begin{array}{ll}\frac{0.00071}{0} \\
0.0014\end{array}$ & 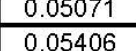 & & & $\frac{196.49}{36391}$ & $\frac{91.15}{1066}$ & $\frac{9.11}{1189}$ & 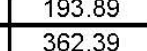 & $\frac{4.43}{7.55}$ & 7.55 & & $\frac{12.31}{9191}$ & & & & & & & $\frac{173}{174}$ \\
\hline & 426 & & 248 & & & & & & & & & & 9.54 & & & 700 & & & & & & & octordata & & \\
\hline & 128 & 73 & 1.74 & 0.54808 & & 0.07076 & & 0.05618 & 0.00274 & & & 17.02 & 16.88 & & 9.55 & 9.54 & & & 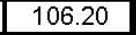 & 440.73 & & & & 93 & 177 \\
\hline 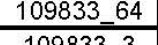 & $\frac{80}{80}$ & 24 & $\frac{3.27}{329}$ & 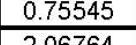 & 0.03688 & 0.092899 & 0.01979 & 0.05988 & 0.00291 & 0.15 & $\begin{aligned} 571.38 \\
512\end{aligned}$ & $\frac{21.50}{2.50}$ & $\frac{21.28}{2.28}$ & 572.260 & $\frac{11.61}{12.681}$ & $\frac{11.60}{127}$ & 566.52 & 109.29 & 05.66 & 572.60 & 11.61 & 11.60 & ns & 102 & 1774 \\
\hline & 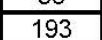 & 17 & & & & 0.21844 & & 0 & & & 1150.10 & 20.01 & 28.00 & & 22.81 & 2.17 & & & & 1104.1010 & .81 & & $\frac{15}{n-15}$ & & \\
\hline & & & & & & & & & & & & & 22.7 & & & & & & & & 20 & & & 111 & \\
\hline
\end{tabular}


30 Report of Investigations 2014-2

Sample name: 09TMH323A A2Z sample ID: 1098-33

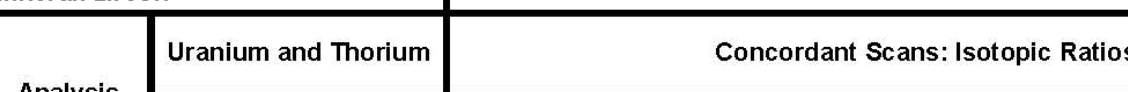

Analysis

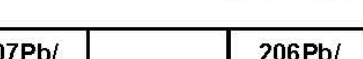

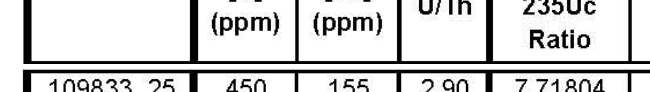

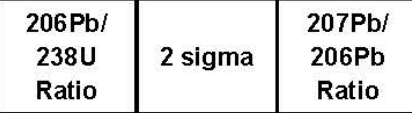

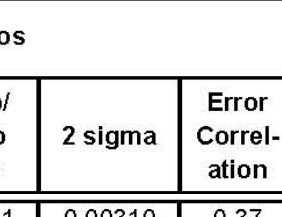

Concordant Scans: Ages

Preferred Age

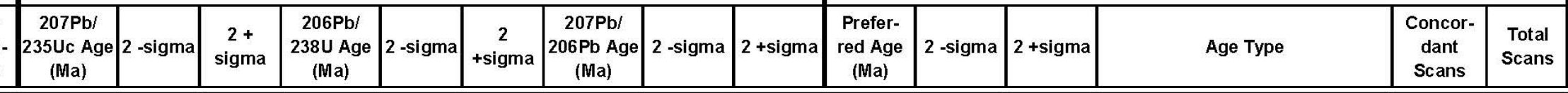

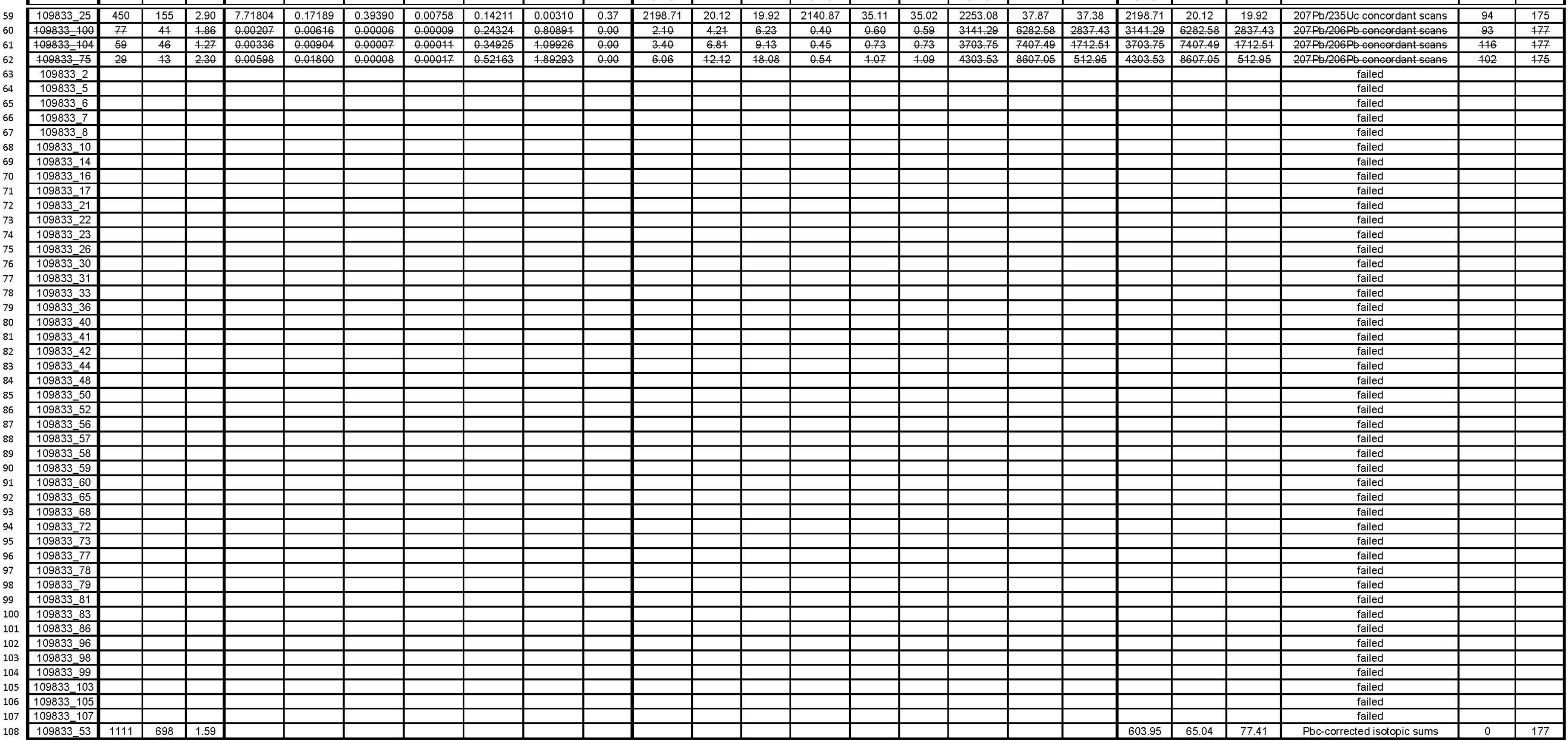




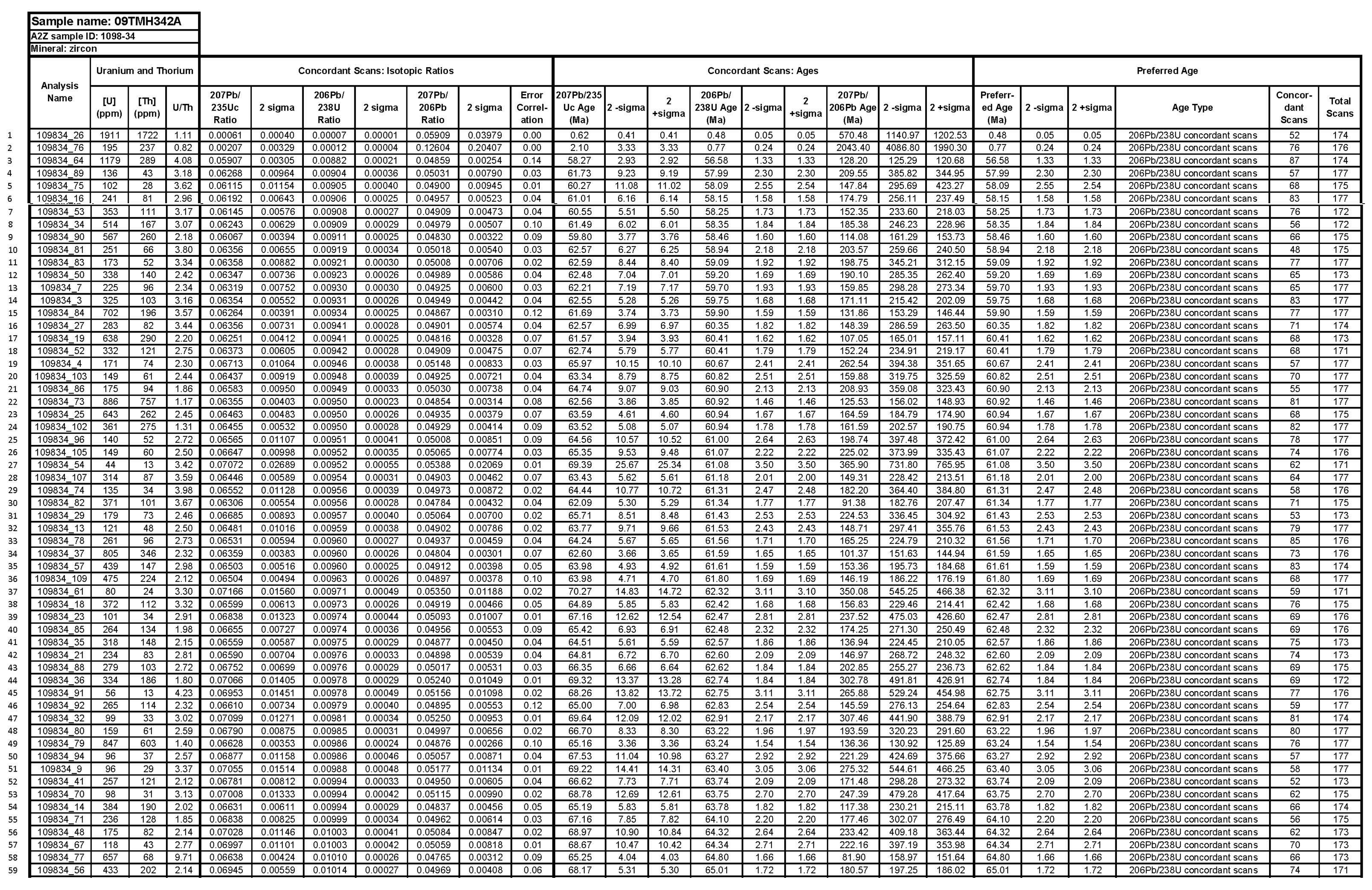


32 Report of Investigations 2014-2

Sample name: 09TMH342A \begin{tabular}{l} 
A2Z sample ID: 1098-34 \\
\hline Mineral: zircon
\end{tabular}

\begin{tabular}{|l|l}
\hline & Uranium and Thoriu \\
\hline
\end{tabular}

Concordant Scans: Isotopic Ratios
Thorium \begin{tabular}{|c|c|c|c|c|c|c|c|c|c|}
\hline $\begin{array}{c}{[\mathrm{UU}]} \\
(\mathrm{ppm})\end{array}$ & $\begin{array}{c}{[\mathrm{Th}]} \\
(\mathrm{ppm})\end{array}$ & $\mathrm{U} / \mathrm{Th}$ & $\begin{array}{c}207 \mathrm{~Pb} / \\
23 \mathrm{Vu} \\
\text { Ratio }\end{array}$ & 2 sigma & $\begin{array}{c}206 \mathrm{~Pb} / \\
238 \mathrm{~B} \\
\text { Ratio }\end{array}$ & 2 sigma & $\begin{array}{c}207 \mathrm{~Pb} / \\
206 \mathrm{~Pb} \\
\text { Ratio }\end{array}$ & 2 sigma & $\begin{array}{c}\text { Error } \\
\text { Correl- } \\
\text { ation }\end{array}$ \\
\hline
\end{tabular}

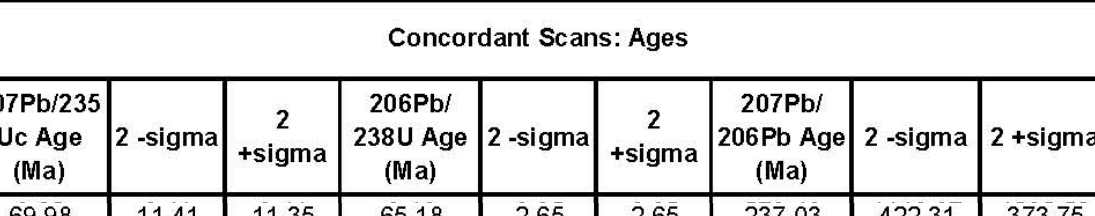

\begin{tabular}{|l|l|l|l|l}
\hline \multicolumn{2}{|c}{ Preferred Age } \\
\hline $\begin{array}{c}\text { Preferr- } \\
\text { ed Age } \\
\text { (Ma) }\end{array}$ & 2 -sigma & $2+$ sigma & Age Typ \\
\hline
\end{tabular}
Age Type \begin{tabular}{c|c}
$\begin{array}{c}\text { Concor- } \\
\text { dant } \\
\text { Scans }\end{array}$ & $\begin{array}{c}\text { Total } \\
\text { Scans }\end{array}$ \\
\hline 5 & 173 \\
\hline
\end{tabular}

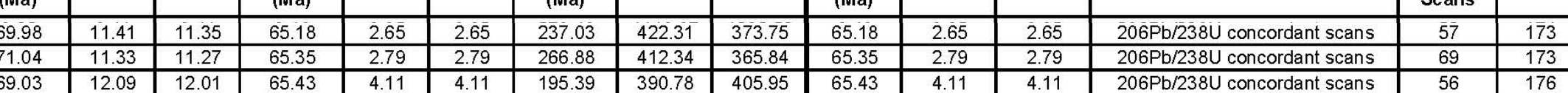

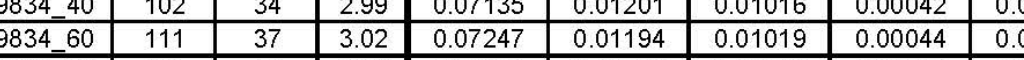
\begin{tabular}{l|l|l|l|l|l}
34 & 92 & 35 & 2.62 & 0 \\
\hline & 126 & 48 & 264 & 000 \\
\hline
\end{tabular}

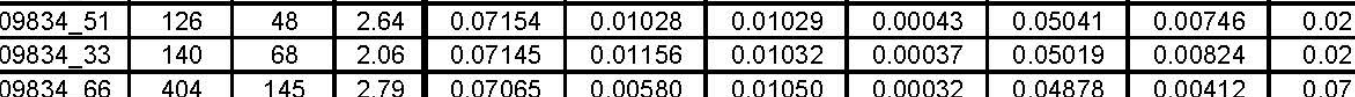

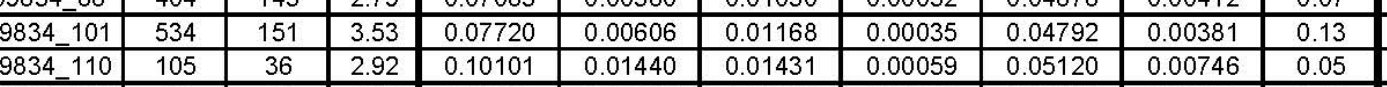

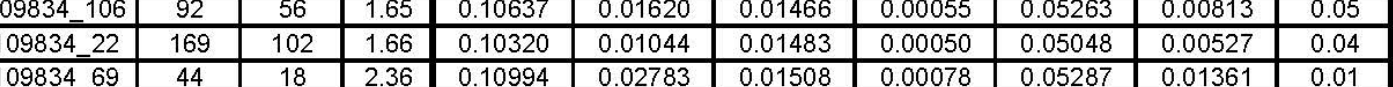

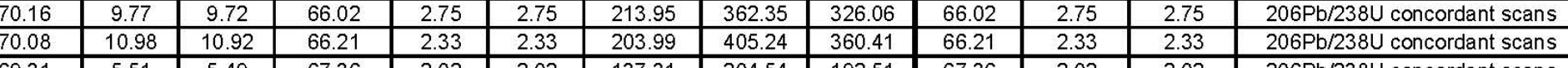
\begin{tabular}{|c|c|c|c|c|c|c|c|c|c|c|c|c|c|c|}
\hline 75.51 & 5.72 & 5.71 & 74.88 & 2.25 & 2.25 & 95.41 & 190.62 & 182.92 & 74.88 & 2.25 & 2.25 & $206 \mathrm{~Pb} / 238 \mathrm{U}$ concordant scans & 70 & 177 \\
\hline 97.71 & 13.33 & 13.24 & 91.59 & 3.77 & 3.77 & 249.72 & 353.91 & 319.14 & 91.59 & 3.77 & 3.77 & $206 \mathrm{P} / 238 \mathrm{U}$ concordant scans & 61 & 177 \\
\hline
\end{tabular}

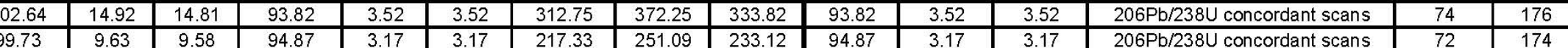
\begin{tabular}{l|l|l|l|l|l|l|l|l|l|l|}
\hline 09834696 & 44 & 18 & 2.36 & 0.10994 & 0.02783 & 0.01508 & 0.00078 & 0.05287 & 0.01361 & 0.01 \\
\hline 0983472 & 109 & 26 & 4.14 & 0.10588 & 0.01531 & 0.01523 & 0.00051 & 0.05043 & 0.00741 & 0.02 \\
\hline
\end{tabular}

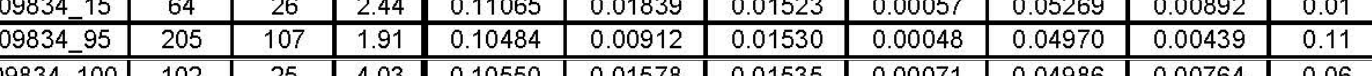
\begin{tabular}{l|l|l|l|l|l|l|l|l|l|l|l|l|}
\hline $09834-100$ & 102 & 25 & 4.03 & 0.10550 & 0.01578 & 0.01535 & 0.00071 & 0.04986 & 0.00764 & 0.06 \\
\hline 09834108 & 120 & 49 & 2.43 & 0.10723 & 0.01363 & 0.01550 & 0.00054 & 0.05018 & 0.00650 & 0.05 \\
\hline
\end{tabular}

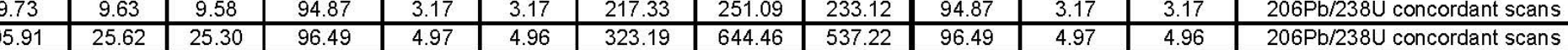

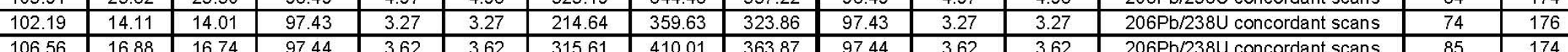
\begin{tabular}{|l|l|l|l|l|l|l|l|l|l|l|l|l|l|l|l|l|l|l|}
\hline 101.24 & 8.40 & 8.37 & 97.88 & 3.08 & 3.08 & 181.03 & 212.60 & 199.60 & 97.88 & 3.08 & 3.08 & $206 \mathrm{~Pb} / 238 \mathrm{U}$ concordant scans & 91 & 177 \\
\hline
\end{tabular}

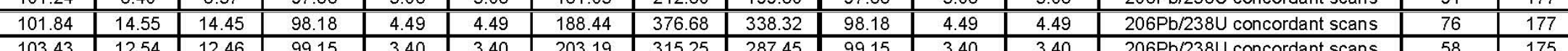

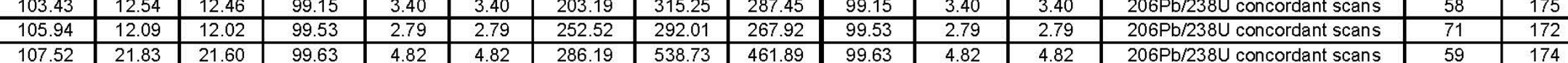
\begin{tabular}{l|c|c|c|c|c|c|c|c|c|c|c|c|}
\hline \\
\hline $09834-12$ & 243 & 113 & 2.616 & 0.10840 & 0.01227 & 0.01561 & 0.00051 & 0.05035 & 0.00586 & 0.02 \\
\hline
\end{tabular} \begin{tabular}{|c|c|c|c|c|c|c|c|c|c|c|c|c|c|}
\hline & 2.39 .94 & 2.69 & 210.60 & 204.39 & 192.33 & 99.94 & 2.70 & 2.69 \\
\hline
\end{tabular} \begin{tabular}{|l|l|l|l|l|l|l|l|l|l|l|l|l|l|l|l|l|l|l|l|l|l|l|l|l|l|l|l|l|l|l}
\hline $34-87$ & 189 & 112 & 1.68 & 0.10828 & 0.01048 & 0.01568 & 0.00050 & 0.05009 & 0.00497 & 0.05 & 104.39 & 9.62 & 9.58 & 100.29 & 3.16 & 3.16 & 198.97 & 239.02 & 222.70 & 100.29 & 3.16 & 3.16 \\
\hline
\end{tabular}

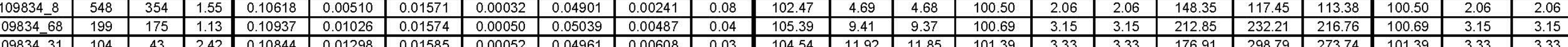
\begin{tabular}{l|c|c|c|c|c|c|c|c|c|c|c|}
\hline $09834-31$ & 104 & 43 & 2.42 & 0.10844 & 0.01298 & 0.01585 & 0.00052 & 0.04961 & 0.00608 & 0.03 & 10 \\
\hline $09834-38$ & 185 & 147 & 1.26 & 0.10746 & 0.00951 & 0.01587 & 0.00044 & 0.04910 & 0.00444 & 0.05 \\
\hline
\end{tabular} \begin{tabular}{l|l|l|l|l|l|l|l|l|l|l|l|l}
\hline $09834 \_20$ & 121 & 47 & 2.54 & 0.11215 & 0.01392 & 0.01598 & 0.00055 & 0.05092 & 0.00644 & 0.05 \\
\hline
\end{tabular} \begin{tabular}{|c|c|c|c|c|c|c|c|c|c|c|c|}
\hline $09834-49$ & 88 & 23 & 3.80 & 0.11204 & 0.01911 & 0.01598 & 0.00064 & 0.05085 & 0.00882 & 0.03 \\
\hline
\end{tabular}

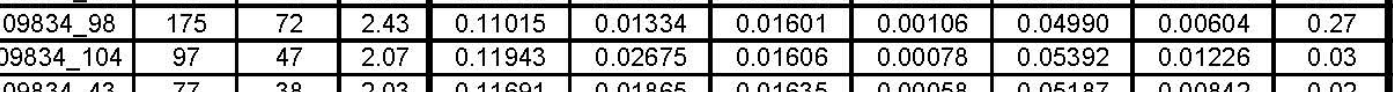
\begin{tabular}{l|l|l|l|l|l|l|l|l|l|l|l|l|l|l|l|l|}
\hline 107.10 & 14.37 & 14.27 & 101.82 & 3.89 & 3.89 & 175.64 & 351.29 & 326.11 & 101.82 & 3.89 & 3.89 & $206 \mathrm{~Pb} / 238 \mathrm{C}$ concordant scans & 66 & 174 \\
\hline
\end{tabular} \begin{tabular}{|l|l|l|l|l|l|l|l|l|l|l|l|l|l|l|l|}
\hline 107.93 & 12.75 & 12.67 & 102.17 & 3.51 & 3.51 & 236.99 & 305.44 & 27.92 .21 & 102.17 & 3.51 & 3.51 & $206 \mathrm{~Pb} / 238 \mathrm{U}$ concordant scans & 56 & 174 \\
\hline 107.83 & 17.52 & 17.37 & 102.19 & 4.07 & 4.06 & 234.20 & 427.22 & 377.60 & 102.19 & 4.07 & 4.06 & $206 \mathrm{~Pb} / 238 \mathrm{U}$ concordant scans & 75 & 172 \\
\hline
\end{tabular}

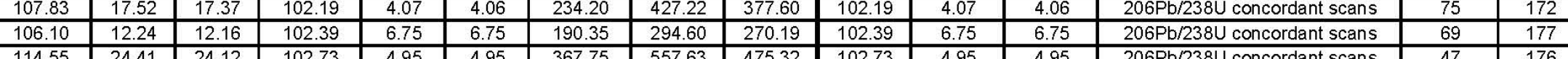
\begin{tabular}{|l|l|l|l|l|l|l|l|l|l|l|l|l|l}
\hline 7.03 & 16.89 & 104.52 & 3.69 & 3.68 & 279.70 & 394.43 & 351.64 & 104.52 & 3.69 & 3.68 \\
\hline
\end{tabular}

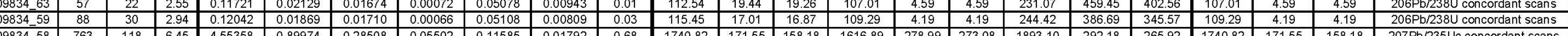

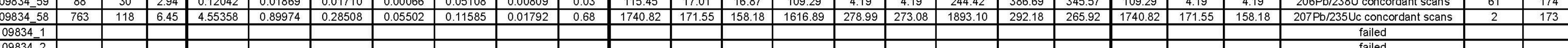

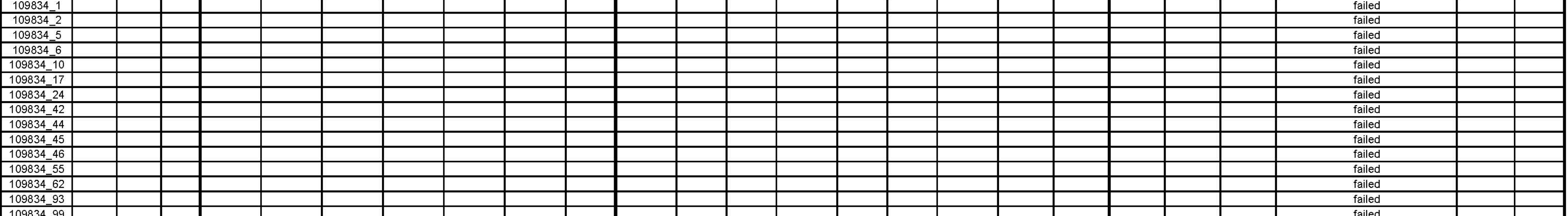




\section{Appendix C}

\section{A Brief introduction to Lahars and Lahar Processes}

The term "lahar" was once considered by some workers to be ambiguous and its use in the volcaniclastic sedimentology and volcanology literature ostensibly lacked utility (Smith, 1986). However, a working definition proposed by Smith and Fritz (1989) is now widely adopted and use of the term has remained ubiquitous. As summarized by Vallance (2005), lahar is "a general term for a rapidly flowing, gravity-driven mixture of rock debris and water (other than normal streamflow) from a volcano," explicitly referring to a process and not a deposit. Furthermore, volcaniclastic sedimentologists generally limit use of lahar solely to encompass hyperconcentrated- and debris-flow processes (Cronin and others, 1999; Rodolfo, 2000; Vallance, 2000, 2005; Pierson, 2005). It is broadly recognized, however, that lahars are commonly genetically related to other volcanogenic processes that are not included in this narrowed definition - for example, debris avalanche, primary pyroclastic flow, and water flow.

Lahars are typically temporally and sedimentologically punctuated, relatively high discharge volcano-hydrologic events (in the sense of Smith and Lowe, 1991) sourced from high-relief, volcaniclastic-detritus-rich volcanic environments. Such events comprise flowing mixtures of water and sediment, with hyperconcentrated flows likened to "dirty motor oil" (Pierson, 1995) or appearing to be "viscous and oily" (Cronin and others, 2000), whereas debris flows are more similar to "liquefied slurr[ies]...resembling wet concrete" (Pierson, 1995). Lahar deposits commonly record very large sedimentologic events, as is indicated by these observed and inferred lahar-flow parameters: (1) flow velocities on the order of up to $40 \mathrm{~m} / \mathrm{s}$ (Pierson, 1995; Rodolfo, 2000), (2) total flow volumes from tens of thousands to greater than one billion $\mathrm{m}^{3}$ (Major and others, 2005; Vallance, 2005), (3) discharge of thousands to several hundreds of thousands of cubic meters per second (Pierson, 1985, 1995; Major and others, 2005), (4) channelized flow depths to many tens of meters (Scott, 1989; Pierson and others, 1990), (5) unconfined flow depths to $5 \mathrm{~m}$ (Pierson and others, 1990), and (6) runout distances of many tens of kilometers to nearly $100 \mathrm{~km}$ (Waitt and others, 1983; Pierson, 1985; Scott, 1989; Cronin and others, 1999, 2000; Zernack and others, 2009). An especially large clayrich, cohesive lahar (the so-called Osceola Mudflow) was generated during a sector collapse event at Mount Rainier ca. $5.6 \mathrm{ka}$, with flow depths to $100 \mathrm{~m}$, flow velocities up to $\sim 19 \mathrm{~m} / \mathrm{s}$, peak discharge of $2,500,000 \mathrm{~m}^{3} / \mathrm{s}$, a run-out distance of $120 \mathrm{~km}$, and resultant lahar deposits up to $25 \mathrm{~m}$ thick (Crandell, 1971; Vallance and Scott, 1997). 


\section{Sediment-Water Continuum}

Flowing mixtures of water and sediment lie along a sediment-water continuum, with relatively dilute water flow serving as one endmember flow type and relatively fluid-poor, solids-dominated flow - commonly referred to as debris avalanche in volcanic environments - as the other (Smith and Lowe, 1991); lahar flow types (such as hyperconcentrated and debris flow) occur along the middle of this spectrum (fig. 12). Hyperconcentrated and debris flows each encompass different flow rheologies, dominant sediment-transport mechanisms, and deposit characteristics, which are broadly summarized in figure 12 .

\section{$\underline{\text { Lahar Generation }}$}

Lahars commonly occur in continental volcanic arcs, a setting well suited to prolific generation of unconsolidated volcaniclastic detritus, which is typically a key lahar ingredient. Explosive volcanic eruptions can nearly instantaneously mantle a landscape with enormous volumes (many cubic kilometers) of pyroclastic material, and post-eruption sediment yields can be several orders of magnitude greater than pre-eruption yields (Major and others, 2000). Bulking of water floods with easily erodible and loose volcaniclastic sediment readily available for transport is an especially common means of generating clay-poor, cohesionless lahars (for example, see summary by Vallance, 2000). Several processes in a continental arc setting can result in volumetrically substantial water floods - either syn- or post-eruptively - including: (1) sudden melting of snow and ice resulting from interaction with hot pyroclastic material (for example, Waitt and others, 1983; Major and Newhall, 1989; Waitt, 1989; Pierson and others, 1990; Thouret, 1990; Pierson, 1995, 1999); (2) catastrophic discharge of naturally dammed lakes (Neall, 1976; Waitt and others, 1983; Glicken and others, 1989; Waythomas and others, 1996); and (3) torrential rainfall (Rodolfo and others, 1989; Rodolfo and Arguden, 1991; Pierson and others, 1996; Rodolfo and others, 1996; Scott and others, 1996). Debris-avalanche-related lahars (Glicken, 1991, 1996; Palmer and others, 1991; Scott and others, 1995; Procter and others, 2009; Zernack and others, 2009) are commonly clay-rich and can form astoundingly large cohesive debris flows.

\section{Flow Transformations and Distinguishing Criteria}

It is widely recognized that clay-poor lahars are prone to flow transformations (in the sense of Pierson, 1999; see summaries by Pierson, 2005; and Vallance, 2005; also Fisher, 1983). Flow transformations are a consequence of flow rheology, which influences sediment transport and deposition mechanisms such that various flow types commonly yield distinguishable deposits. Tabulated criteria to aid in distinguishing among deposit types of various volcaniclastic sediment-water flows have been published (table 1 in Smith, 1986; figure 10 in Scott, 1988; table 1 in Procter and others, 2009; table 3 in Zernack and others, 2009), and we include a subset of these criteria in figure 12. 
The dashed lines in figure 12 represent flow-type transitions and are placed at 10 percent, 50 percent, and 70 percent sediment concentration by volume, which are typical thresholds in volcanic settings (Pierson and others, 2009). However, Pierson (1995; also Pierson and Costa, 1987) noted that grain size distribution and clay content — more so than overall sediment fraction (weight or volume percent) - greatly influence where these flow transitions occur in the continuum. Therefore, no uniquely definable sediment:water ratios can be ascribed to effectively predict exactly where along the flow continuum transformations will occur during natural flow events (Vallance, 2005; Pierson 2005).

Flow transformations of cohesionless lahars are generally attributable to bulking — addition of sediment to a flow (Scott, 1988) — or dilution due to either incorporation of surface water into a flow (Pierson and Scott, 1985) or release of sediment from the flow (Smith and Lowe, 1991; Cronin and others, 2000). A typical life cycle of a non-cohesive lahar may involve rapid bulking of sediment from low concentrations associated with dilute stream flow to high concentrations characteristic of debris flows with, undoubtedly, a potentially unrecorded and rapid transition through hyperconcentrated flow and followed by downstream dilution through hyperconcentrated flow to water flow (Pierson and Scott, 1985; Pierson and others, 1990; Cronin and others, 1999). Contrary to the common bulking- and dilution-related flow transformations typical in non-cohesive mass flows, clayrich debris flows tend to retain their flow character throughout a lahar event, resisting downslope flow transformations to more dilute flow types (Vallance, 2005). As briefly discussed above, clayrich, cohesive lahars commonly originate as debris avalanches at hydrothermally altered volcanic edifices that contain sufficient water at the time of flank failure to transform to debris flows (Vallance, 2005) that can flow for up to $100 \mathrm{~km}$ or farther (for example, Scott and others, 1995; Vallance and Scott, 1997). 